Pontifícia Universidade Católica

Juliana Nunes dos Santos

Arquitetura da hospitalidade

Acolhimento do habitante na fronteira entre edifício e cidade

Dissertação de Mestrado

Linha de pesquisa: Métodos e Processos

Dissertação apresentada ao Programa de PósGraduação em Arquitetura e Urbanismo da PUCRio como requisito parcial para obtenção do grau de Mestre em Arquitetura.

Orientador: Prof. Fernando Espósito

Rio de Janeiro

Maio de 2021 
Pontifícia Universidade Católica

Juliana Nunes dos Santos

\section{Arquitetura da hospitalidade \\ Acolhimento do habitante na fronteira entre edifício e cidade}

Dissertação apresentada como requisito parcial para a obtenção do grau de Mestre pelo Programa de Pósgraduação em Arquitetura da PUC-Rio. Aprovada pela Comissão Examinadora abaixo assinada.

Prof. Fernando Espósito

Orientador

Departamento de Arquitetura e Urbanismo - PUC-Rio

Profa. Maíra Martins

Departamento de Arquitetura e Urbanismo - PUC-Rio

Prof ${ }^{a}$. Roberta Edelweiss

Departamento de Arquitetura e Urbanismo - UFSC

Rio de Janeiro, 27 de maio de 2021 
Todos os direitos reservados. É proibida a reprodução total ou parcial do trabalho sem autorização da universidade, da autora e do orientador.

\section{Juliana Nunes dos Santos}

Graduou-se em Arquitetura e Urbanismo na Pontifícia Universidade Católica do Rio de Janeiro (2016). Possui especialização em Design de Espaços pelo Istituto Europeo di Design do Rio de Janeiro (2017). Seu Trabalho Final de Graduação foi o primeiro colocado na categoria de urbanismo e paisagismo na premiação anual do Arquiteto do Amanhã IAB-RJ (2017) e foi também o trabalho vencedor do prêmio Grandjean de Montigny CAU-RJ (2017).

Ficha Catalográfica

Santos, Juliana Nunes dos

Arquitetura da hospitalidade : acolhimento do habitante na fronteira entre edifício e cidade / Juliana Nunes dos Santos ; orientador: Fernando Espósito. - 2021.

120 f. : il. color. ; $30 \mathrm{~cm}$

Dissertação (mestrado)-Pontifícia Universidade Católica do Rio de Janeiro, Departamento de Arquitetura e Urbanismo, 2021. Inclui bibliografia

1. Arquitetura e Urbanismo - Teses. 2. Hospitalidade. 3. Habitar. 4. Fronteira. 5. Arquitetura. 6. Cidade. I. Espósito Galarce, Fernando. II. Pontifícia Universidade Católica do Rio de Janeiro. Departamento de Arquitetura e Urbanismo. III. Título. 
Para minha avó Maria (in memoriam), minha mais linda lembrança de acolhimento. 


\section{Agradecimentos}

À PUC-Rio, universidade onde me formei e a qual retornei para realização do mestrado, por oferecer todos os subsídios necessários para uma formação completa.

Ao meu orientador, Fernando Espósito, pela profunda dedicação na orientação desta pesquisa e por todo o estímulo frente aos desafios da formação acadêmica.

A todos os professores e professoras que contribuíram para a construção desta pesquisa, cada um com seu olhar, em especial, às professoras Maíra Machado e Roberta Edelweiss que compõem a banca examinadora.

Às funcionárias do programa, por toda disposição em ajudar durante este período.

Às colegas de turma, por todas as vezes que se dispuseram a ouvir reflexões oriundas do trabalho e contribuir de algum modo.

Aos meus pais, meus maiores incentivadores, por todo apoio e estímulo a uma contínua capacitação profissional.

O presente trabalho foi realizado com apoio da Coordenação de Aperfeiçoamento de Pessoal de Nível Superior - Brasil (CAPES) - Código de Financiamento 001 


\section{Resumo}

Nunes dos Santos, Juliana; Espósito Galarce, Fernando (orientador). Arquitetura da hospitalidade: Acolhimento do habitante na fronteira entre edifício e cidade. Rio de Janeiro, 2021. 120p. Dissertação de Mestrado - Departamento de Arquitetura e Urbanismo, Pontifícia Universidade Católica do Rio de Janeiro.

$\mathrm{O}$ que gera hospitalidade na arquitetura? Como a arquitetura acolhe o habitante nas fronteiras de transição do espaço? Esses são os principais questionamentos que motivam o trabalho. O objeto de estudo é a hospitalidade na arquitetura. Em meio a cidades contemporâneas frequentemente hostis, a reflexão acerca de uma arquitetura da hospitalidade se faz necessária. A ideia de fronteira, enquanto recorte físico-social, se mostra potencial para esta investigação pois, por meio do tratamento dela, é possível a costura entre diferentes espaços, possibilitando lugares de acolhimento. Assim, o trabalho tem como objetivo principal, portanto, investigar o acolhimento do habitante nas fronteiras do espaço. Alguns conceitos emergem de modo relevante na compreensão das relações estudadas, como os conceitos de lugar, de habitar, de afeto e de fronteira. Metodologicamente, para os estudos de caso, os conceitos antes mencionados são articulados com ferramentas de análise contextual (físico, histórico e social) como croquis de observação, elaboração de digramas, dimensionamento e colagem. Partiu-se de obras emblemáticas, em diferentes contextos e escalas, até espaços do cotidiano carioca, analisados nos estudos de caso (Praça São Salvador e Mureta da Urca). A escolha destes se deve principalmente ao caráter coletivo desses lugares, marcado pela presença de elementos que oferecem hospitalidade àquele que habita, associado a um contexto favorável à realização do acolhimento. Procura-se reconhecer nessas análises os gestos que conferem acolhimento ao lugar por meio da arquitetura. Propõe-se aqui que a hospitalidade em arquitetura se dá por meio de diversas estratégias que operam em diferentes escalas. Desde a escala do corpo, passando pela escala do edifício, até a escala urbana.

\section{Palavras-Chave}

Hospitalidade; Habitar; Fronteira; Arquitetura; Cidade 


\section{Abstract}

Nunes dos Santos, Juliana; Espósito Galarce, Fernando (advisor). Architecture of hospitality: Welcoming of dweller on the border between building and city. Rio de Janeiro, 2021. 120p. Dissertação de Mestrado Departamento de Arquitetura e Urbanismo, Pontifícia Universidade Católica do Rio de Janeiro.

What generates hospitality in architecture? How does architecture welcome dweller at the transition boundaries of space? These are the main questions that motivate the work. The object of study is hospitality in architecture, based on the relationship between dweller and place. Amidst contemporary cities that are often hostile, thinking about architecture of hospitality is necessary. The idea of a border, as a spatial cut-out, reveals potential for this investigation because, through its treatment, it is possible the sewing between different spaces, enabling places of welcoming. Thus, the work has as main objective, therefore, to investigate the welcoming of dweller at the borders of space. Some concepts emerge in a relevant way in the understanding of studied relationships, such as the concepts of place, of dwell, of affection and of border. Methodologically, for the case studies, the mentioned concepts are articulated with contextual analysis tools (physical, historical, and social) such as observation sketches, diagrams, dimensioning and collage. The investigation provides, in this way, new possibilities and the necessary subsidies for the analysis of architectural works in search of a hospitality of place. It started from emblematic works, in different contexts and scales, up to everyday spaces in Rio de Janeiro, analyzed in the study cases (Praça São Salvador e Mureta da Urca). The choice of these is mainly due to the collective character of these places, characterized by the presence of elements that offer hospitality to those who dwell it, associated with a favorable context for hosting. It seeks to recognize in these analyzes the gestures that provides welcoming to the place through architecture. It is proposed here that hospitality in architecture occurs through different strategies that operate in different scales. From the body scale, through the building scale, until the urban scale.

\section{Keywords}

Hospitality; Dwell; Border; Architecture; City 


\section{Sumário}

1. Introdução

2. O lugar da hospitalidade: a relação entre espaço e habitar

2.1. Da percepção a experiência

2.2. O conceito de lugar 31

2.3. A essência do habitar

3. Hospitalidade

42

3.1. Conceito de hospitalidade 42

3.2. Em busca de uma arquitetura da hospitalidade 45

3.3. (Po)ética da hospitalidade 60

3.3.1. Poética da hospitalidade 61

3.3.2. Ética da hospitalidade 63

4. Fronteira da hospitalidade $\quad 67$

$\begin{array}{ll}\text { 4.1. Conceito de fronteira } & 67\end{array}$

4.2. Escala humana e a experiência corporificada do espaço 69

4.3. Fronteira como lugar da hospitalidade 73

5. Observação do espaço habitado 78

5.1. Ferramentas de análise da hospitalidade 78

5.2. Espaços investigados 86

5.2.1. Praça São Salvador 86

5.2.2. Mureta da Urca 96

5.3. Matriz de análise da hospitalidade 106

$\begin{array}{lr}\text { 6. Considerações Finais } & 109\end{array}$

$\begin{array}{lr}\text { 7. Referências bibliográficas } & 118\end{array}$ 


\section{Lista de Figuras}

Figura 1 - Quadro síntese referencial teórico-metodológico

Figura 2 - Diagrama conceitual

Figura 3 - Corte Praça das Artes

Figura 4 - Praça São Salvador

Figura 5 - Forró na Praça São Salvador

Figura 6 - Mureta da Urca

Figura 7 - Ribeira das Naus

Figura 8 - Mobiliário Ribeira das Naus

Figura 9: Conjunto Habitacional da Bouça

Figura 10: Implantação Conjunto Habitacional da Bouça

Figura 11: Conjunto Habitacional Rincão

Figura 12: Implantação Conjunto Habitacional Rincão

Figura 13: SESC Pompeia

Figura 14: Praça Triumfalnaya

Figura 15: Praça Triumfalnaya

Figura 16: Balanços Praça Triumfalnaya

Figura 17: Praça Triumfalnaya

Figura 18: Vista aérea Edifício Diagonal

Figura 19: Parque interno no miolo da quadra L'illa Diagonal

Figura 20: Acesso L'illa Diagonal

Figura 21: Acesso Centro Universitário Maria Antonia

Figura 22: Praça interna do Centro Universitário Maria Antonia

Figura 23: Edifício Argentina e contexto urbano

Figura 24: Integração gerada pela implantação Edifício Argentina

Figura 25: Hospitalidade da via peatonal Ed. Argentina

Figura 26: Foto aérea Praça São Salvador

Figura 27: 3D fotorrealista Praça São Salvador e imediações

Figura 28: Croquis Praça São Salvador

Figura 29: Croqui da Praça São Salvador em dia de semana, pela tarde

Figura 30: Croqui da Praça São Salvador em domingo com evento, pela manhã 
Figura 31: 3D Praça São Salvador com destaque para as dimensões da hospitalidade

Figura 32: Bancos Praça São Salvador

Figura 33: Dimensões banco Praça São Salvador

Figura 34: Elementos da hospitalidade na Praça São Salvador e suas respectivas escalas

Figura 35: Colagem Praça São Salvador

Figura 36: Foto aérea Mureta da Urca

Figura 37: Mureta da Urca

Figura 38: Croquis Mureta da Urca

Figura 39: Croqui da Mureta quarta-feira, pela tarde

Figura 40: Croqui da Mureta sexta-feira, início da noite

Figura 41: 3D Mureta da Urca com destaque para dimensões da hospitalidade

Figura 42: Dimensões Mureta da Urca

Figura 43: Elementos da hospitalidade na Mureta da Urca e suas respectivas escalas

Figura 44: 3D fotorrealista da Mureta da Urca

Figura 45: 3D fotorrealista da enseada

Figura 46: Colagem Mureta da Urca

Figura 47: Matriz de análise da hospitalidade

Figura 48: Diagrama nuances da hospitalidade

Figura 49: Diagrama conceitual fronteira expandida 


\section{Introdução}

$\mathrm{O}$ ato de projetar em arquitetura e urbanismo é de grande importância na qualidade de vida das pessoas que habitam o espaço. Ao falar de ato projetual, não se trata só do ato de pensar ou idealizar um espaço e edificação, nem de desenhar e modelar essas ideias por meio das ferramentas próprias da disciplina arquitetônica e urbana. $\mathrm{O}$ ato de projetar envolve também a pré-visualização do lugar futuro, das formas de habitar possíveis nesse lugar que ainda não existem e, portanto, das relações físicas, sociais e históricas que existem e aquelas que também poderiam chegar a existir. Nesse sentido, projetar não implica apenas idealizar edifícios e espaços, mas também as relações humanas de habitabilidade que ocorrem em, com e entre esses espaços e seres, configurando assim lugar. Portanto, um projeto pode também dar origem a rupturas que influenciam profundamente a dinâmica espacial do espaço habitado. Henri Lefebvre defende um urbanismo condicionado ao habitar humano ao expor que o "o espaço concreto é substituído por um espaço abstrato"1 na prática projetual arquitetônica, sendo este espaço concreto o do habitar. "O arquiteto que desenha, o urbanista que compõe o plano-massa, veem, de cima e de longe, seus 'objetos', imóveis e vizinhanças"2. O autor destaca, nesse sentido, um afastamento da arquitetura em relação à tarefa de construção do habitar humano, diretamente relacionada a um papel político e social da profissão. "Como o usuário não poderia se sentir [excluído] no encontro e no diálogo (se há diálogo e encontro) entre o arquiteto e urbanista?"3. Josep Maria Montaner destaca a crise de uma arquitetura entendida como objeto isolado e monumental e como a partir disso surgem novos encaminhamentos para o projeto arquitetônico. É nesse contexto que se identifica uma crescente valorização da arquitetura relacionada a fenomenologia, que atribui grande valor à experiência, e, portanto, à percepção dos sentidos.

\footnotetext{
${ }^{1}$ LEFEBVRE, 1999, p. 109.

2 LEFEBVRE, 1999, p.166.

${ }^{3}$ Ibidem, p170.
} 
(...) diversas vertentes pós-modernas ajudaram a abrir espaço para a experiência como contraponto ao despotismo da razão e do olhar único, em favor de um tipo de projeto inclusivo que incorpore a perspectiva de gênero, o olhar de e para o 'outro' e o objetivo de uma arquitetura participativa. ${ }^{4}$

Partindo dessa premissa de afastamento do arquiteto em relação ao habitar humano, observa-se a conformação de cidades cada vez menos atentas ao habitante. É nesse contexto que emerge a relevância do tema da hospitalidade dentro da prática projetual arquitetônica. Por meio dela é possível questionar e repensar a construção do espaço urbano contemporâneo. Isto porque a hospitalidade pressupõe um acolhimento idealmente irrestrito, marcado por uma capacidade de receber o outro, o que expõe uma dimensão ética em arquitetura.

O contexto das cidades atuais revela um crescente afastamento do arquiteto em relação ao habitante, que resulta na conformação de um espaço construído frequentemente pouco hospitaleiro. A demanda por cidades mais humanas decorre do fato de que tal dimensão tem sido pouco abordada no âmbito de projeto, em suas variadas escalas.

A arquitetura, quando pouco comprometida com seu contexto, físico e sociocultural, atua diretamente na construção de uma cidade eventualmente inóspita, afetando dessa forma a experiência espacial do habitante. Cidade e arquitetura são vistas aqui como um mesmo projeto, proveniente de um olhar integrado indispensável. $\mathrm{O}$ arquiteto seria, nesse sentido um articulador da relação entre habitante e contexto, entre sociedade e lugar onde habita, destacando a “impossível dissociação entre arquitetura, contexto e a interpretação que o arquiteto faz deste a partir de suas próprias experiências e percepções" " "Os prédios raramente são fatos isolados" , de modo que a dinâmica interna das formas urbanas se dá por meio da maneira como os edifícios se relacionam uns com os outros, com os espaços abertos e com a paisagem. "O ambiente construído é mais que um reflexo da economia ou da política; para além dessas condições, as formas do ambiente construído são resultado de uma vontade." A arquitetura transforma demandas humanas, localizadas em um contexto físico e sociocultural, em um projeto que se materializa em ambiente construído.

\footnotetext{
${ }^{4}$ MONTANER, 2017, p.13.

${ }^{5}$ ESPÓSITO, 2011, p.35 (tradução da autora).

${ }^{6}$ SENNETT, 2018, p. 12.

${ }^{7}$ Idem.
} 
Em nossa sociedade pós-moderna, dominada por uma racionalidade superficial e uma dependência empírica, mensurável e demonstrável, as dimensões corporais e mentais da existência humana são continuamente suprimidas. ${ }^{8}$

Diferentes estratégias do acolhimento ${ }^{9}$ na escala do edifício constroem pouco a pouco a cidade que habitamos, o que contribuirá para a definição, de alguma forma, como hostil ou hospitaleira à escala humana. Tais questões emergem a partir da identificação de uma eventual falta de articulação entre arquitetura, cidade e habitante, que se traduz no caráter dos espaços que temos construído ao longo do tempo. Sendo assim, olhar a arquitetura ao nível do olhar humano, compreendendo como o corpo transita entre espaços de diferentes escalas é importante para a presente investigação. Torna-se cada vez mais relevante entender a construção nas suas diversas escalas, de modo a compreender não apenas a dimensão do edifício, mas também sua dimensão afetiva e urbana. É nesse contexto que a hospitalidade emerge como possível resposta para as questões apontadas.

O componente afetivo aparece aqui, não necessariamente como um aspecto comportamental do habitante, mas como uma atitude projetual. Ao promover a permeabilidade da fronteira, a arquitetura estimula encontros e o convívio entre as pessoas por meio do projeto. “A riqueza civil e arquitetônica, urbanística e morfológica de uma cidade é a de seus espaços coletivos, a de todos os lugares onde a vida cotidiana é desenvolvida, representada e lembrada"10.

Embora o ambiente físico não tenha influência direta na qualidade, no conteúdo e na intensidade dos contatos sociais, arquitetos e urbanistas podem influenciar as possibilidades de encontrar, ver e ouvir pessoas, possibilidades que carregam qualidade em si mesmas e se tornam importantes como pano de fundo e ponto de partida para outras formas de contato. A presença de outras pessoas, de atividades e acontecimentos, de inspiração e estímulos, é uma das qualidades mais importantes dos espaços públicos. ${ }^{11}$

Desta forma, o caráter coletivo de um espaço não deve depender do tipo de domínio da construção, pública ou privada, mas de uma postura hospitaleira frente ao habitante, marcada pelo que Jan Gehl nomeia como "vida entre edifícios". De acordo com o autor, essa característica encontra-se diretamente relacionada ao

${ }^{8}$ PALLASMAA, 2015, p.51.

${ }^{9}$ Fuão apresenta o acolhimento como desvelamento, que permite ver a hospitalidade na arquitetura.

${ }^{10}$ SOLÀ-MORALES, 1994, p.25.

${ }^{11}$ GEHL, 2006. p.21 (Tradução da autora). 
processo de construção urbana. Gehl destaca o desenvolvimento de cidades que se deu por meio de um processo contínuo de configuração do espaço pelos habitantes.

[...] esse processo lento permitiu uma contínua adaptação e ajuste do ambiente físico às funções da cidade. A cidade não era um objetivo em si, mas uma ferramenta moldada pelo uso. O resultado desse processo - que foi baseado em uma infinidade de experiências acumuladas - foram espaços urbanos que ainda hoje oferecem condições extraordinariamente boas para a vida entre edifícios. ${ }^{12}$

A pesquisa tem como objeto de investigação a hospitalidade na arquitetura, a partir da relação habitante-lugar. A partir de uma análise mais aprofundada do conceito, desdobrada no âmbito da arquitetura, a hospitalidade pressupõe o convívio entre diferentes pessoas, e uma relação mais inclusiva e aberta entre arquitetura e cidade é determinante para a realização desta. O trabalho tem como motivação inicial, portanto, o gesto de acolhimento em relação aos seus habitantes ${ }^{13}$ que uma obra pode estabelecer por meio da sua relação com a cidade.

A compreensão da inter-relação pessoa-espaço construído é elementar para uma arquitetura e urbanismo fundamentados a partir do bem-estar humano. A mediação edifício-cidade determina o caráter do espaço que habitamos, nas suas variadas escalas e, dessa forma, possui papel central no contexto identificado de necessidade de construção de espaços mais hospitaleiros para seus habitantes. Por meio dela pode-se estabelecer uma relação de afeto com o espaço construído. Isto ocorre quando um espaço demonstra, de algum modo, acolher seus usuários por meio de estratégias inerentes à prática projetual arquitetônica, sejam elas, formais ou sensoriais.

O modo como o ser humano percebe o espaço contribui para a investigação de como a construção de um lugar determina os sentimentos despertados por ele. Vale ressaltar, no entanto, que "uma obra de arquitetura não é experimentada como uma série de imagens isoladas na retina [...]. Ela oferece formas e superfícies agradáveis e configuradas para o toque dos olhos e dos demais sentidos [...]"14. A percepção humana aciona diversos sentidos na experimentação do espaço, revelando que a ambiência vai além de questões de cunho visual. A dimensão humana possui claramente uma força motriz nas relações aqui estudadas. Cabe

12 Ibidem, p.47.

${ }^{13}$ De acordo com a abordagem adotada pela pesquisa, adota-se o termo habitante para se referir ao indivíduo que utiliza o espaço, mais adequada a uma leitura orientada pela fenomenologia da arquitetura.

${ }^{14}$ PALLASMA, 2011, p.11. 
ressaltar a importância que o espaço possui no processo de elaboração que o homem tem de si mesmo, ao interagir com ele, altera a realidade e influi decisivamente na construção de sua visão de mundo ${ }^{15}$.

Por meio do estudo da relação bidirecional habitante-lugar obtêm-se os subsídios necessários para a investigação do conceito de hospitalidade dentro da arquitetura, elemento potencial para repensar a construção do espaço arquitetônico contemporâneo, reiterando a relevância do tema proposto. "A hospitalidade [...] apresentou-se como um potente elemento para compreendermos a cidade e a arquitetura" ${ }^{" 16}$. A arquitetura possui, dentro dessa ótica, o potencial de acolher as pessoas, possibilitando repensar a cidade contemporânea a partir de uma perspectiva mais humanizada das dimensões que fazem parte da arquitetura e do urbanismo. "Hospitalidade, em termos físicos arquitetônicos, concretos, é dar lugar ao lugar, abrir o lugar, dar passagem, dar passo ao outro, acolher a diferença" ${ }^{" 17}$. Jacques Derrida ${ }^{18}$ explora o conceito de hospitalidade a partir da relação com o outro, o estrangeiro, que chega às fronteiras. Sob esta ótica vale ressaltar que o hóspede (ou o estrangeiro) “já está, de alguma forma, em casa. Sem ter chegado efetivamente, já ocupa o seu lugar no desejo, na expectativa da sua chegada"19. A hospitalidade em termos arquitetônicos se dá, então, quando um espaço é concebido de modo a esperar e guardar aquele que está por vir, o que significa pensar a partir do outro, independentemente da sua chegada.

Existe uma relação evidente de interpendência entre edifício e seu contexto. Nela reside a justificativa para o recorte espacial escolhido para análise do objeto desta pesquisa. A intervenção em escala arquitetônica necessariamente atua sobre o território na construção da cidade que o abriga. Considerando que o modo como as diferentes formas arquitetônicas coexistem é determinante na experiência espacial do ambiente coletivo, o olhar sobre a fronteira entre espaços, seja ela de permeabilidade ou de isolamento, revela-se necessário. Isto posto, é importante considerar que de acordo com Manuel Sola-Morales a cidade é o lugar onde o

\footnotetext{
${ }^{15}$ DEL RIO; DUARTE; RHEINGANTZ, 2002, p.64.

${ }^{16}$ FUÃO, 2015, p. 43.

${ }^{17}$ Ibidem, p.52.

18 Jacques Derrida - filósofo argelino-francês.

${ }^{19}$ HIGINO, 2010, p. 20.
} 
espaço privado pode ser tão social quanto o espaço público. "Urbanizar o privado é o conceito: isto é, absorvê-lo na esfera do público"20.

O crescimento das cidades, como apontado por Richard Sennett, não gerou formas favoráveis à experimentação, por serem autossuficientes, e não abertas a influências e interações externas. ${ }^{21} \mathrm{~A}$ fronteira que constitui o espaço entre a arquitetura e a cidade (sendo a arquitetura entendida como algo inerente a cidade), se mostra potencial, então, para esta investigação, definindo, desta forma, o recorte físico e social a ser explorado. A fronteira, assumida aqui como espaço entre, é capaz de contribuir para o caráter hospitaleiro de uma arquitetura. "Na situação contemporânea, a arquitetura ainda está na cidade. Faz parte dela e materializa parte dos espaços em que a vida urbana se desenvolve." 22

"Martin Heidegger afirma: 'A fronteira não é aquilo em que uma coisa termina, mas, como já sabiam os gregos, a fronteira é aquilo de onde algo começa a se fazer presente'. As fronteiras de um espaço construído são o chão, a parede e o teto." ${ }^{23}$ As fronteiras são definidas nessa pesquisa como um espaço “entre”, híbrido, que determina o caráter da relação entre interior e exterior, de acordo com a maneira como é constituída. "Habitar é uma atividade que ocorre nos espaços exteriores e interiores. O elo entre esses espaços é criado pela forma material."24

O tema apresenta algumas questões e premissas básicas pertinentes à construção dessa investigação. A experiência humana do espaço é aspecto central e por isso, a escala humana atua de modo determinante na leitura desenvolvida pela pesquisa. Alguns conceitos emergem com um papel importante na compreensão das relações estudadas, como o conceito de lugar, de habitar e de fronteira. Entender como se dá a transição cidade-edifício na experiência do indivíduo demanda um entendimento mais profundo da relação entre ele e o espaço construído.

O conceito de lugar está ligado a "um espaço humanamente habitável dotado de significado" 25 . O conceito de habitar, por sua vez, de acordo com Juhani Pallasmaa, está relacionado com o modo de alguém se relacionar com o mundo ${ }^{26}$.

\footnotetext{
${ }^{20}$ SOLÀ-MORALES, 1994, p.23.

${ }^{21}$ SENNETT, 2018, p.22.

${ }^{22}$ SOLÀ-MORALES, 2020 (tradução da autora).

${ }^{23}$ NOBERG-SCHULZ, 1980, p.13.

${ }^{24}$ JÜRGENHAKE, 2006.

${ }^{25}$ ESPÓSITO, 2012.

${ }^{26}$ PALLASMAA, 2017, p.7.
} 
Busca-se olhar para as fronteiras à luz desses conceitos, no intuito de compreender as possíveis relações entre o sujeito e os "espaços entre". "Usamos a palavra 'Habitar' para nos referirmos às relações entre o homem e o lugar. [...] Quando o homem habita, está simultaneamente localizado no espaço e exposto a um determinado caráter ambiental" 27 . Pallasmaa diz acreditar na "viabilidade de uma arquitetura da reconciliação, uma arquitetura que possa mediar e dar as 'boasvindas" 28 . É importante, para isso, olhar a arquitetura a partir da consciência do indivíduo que a vivencia.

A abordagem baseada em um ponto de vista humano da disciplina de projeto em arquitetura permite explorar os componentes afetivos da elaboração do espaço construído. A concepção de acolhimento, sobre a qual se constrói o conceito de hospitalidade de Derrida, é investigada a partir de seu desdobramento na concepção arquitetônica do espaço construído.

O que funda a arquitetura não são as pedras, os tijolos ou as estacas, mas sim o amor, a hospitalidade, a capacidade de acolher, abraçar e proteger, próprias da arquitetura. Uma arquitetura onde o desejo possa morar, onde a subjetividade possa imperar sobre a domesticação. ${ }^{29}$

A pesquisa explora o conceito de fronteira, em busca das estratégias de acolhimento em arquitetura. Segundo Jane Jacobs os limites seriam elementos passivos dentro da dinâmica urbana, enquanto as fronteiras, exerceriam uma influência ativa ${ }^{30}$, revelando-se mais adequadas ao objeto em estudo. As fronteiras do espaço construído são, desta forma, áreas potenciais na materialização de um acolhimento na arquitetura. Quando dotadas de certa "porosidade" são capazes de estabelecer um território interconectado e hospitaleiro.

"A abertura é condição para a hospitalidade" 31 . O acolhimento no espaço demanda a permeabilidade da abertura. Gehl, ao discorrer sobre as estratégias para garantir que pessoas se reúnam nas áreas construídas, pontua a necessidade de: "abrir os espaços de transição entre a cidade e os edifícios, para que a vida no interior das edificações e a vida dos espaços urbanos funcionem conjuntamente" ${ }^{32}$. Nesse sentido, a tensão entre interior e exterior constrói a investigação acerca do

\footnotetext{
${ }^{27}$ NOBERG-SCHULZ, 1980, p.19 (tradução da autora).

${ }^{28}$ PALLASMAA, 2017, p.39.

${ }^{29}$ FUÃO, 2015, p. 13.

${ }^{30}$ JACOBS, 2009, p.177.

${ }^{31}$ FUÃO, Op. Cit, p.56.

${ }^{32}$ GEHL, 2013, p.232.
} 
acolhimento. Gaston Bachelard ${ }^{33}$, ao tratar da "dialética do exterior e do interior", coloca que "se há uma superfície-limite entre tal interior e tal exterior, essa superfície é dolorosa dos dois lados" ${ }^{34}$. Peter Zumthor pontua que nestas relações desenrola-se o "jogo entre o indivíduo e o público, entre privacidade e o público"35. Para ele, é com isto que a arquitetura trabalha. Ao expor as atmosferas, para ele relacionadas a qualidade arquitetônica, Zumthor levanta, ainda, o aspecto da sedução. Para o autor, é importante não conduzir, mas seduzir. À condução associase o corredor, à sedução, "o deixar andar, o vaguear"36. Essa superfície limítrofe se apresenta como recorte físico-social mais adequado para o presente estudo. "É na indefinição, nas bordas, nas bordas do tempo, nesse cinza onde se localizam as potências dos lugares do acolhimento; é nas bordas que se faz a junção, a costura"37.

Considerando que a maneira como o projeto arquitetônico delimita a relação de uma obra com seu entorno físico imediato é determinante na materialização de uma arquitetura na qual a hospitalidade é percebida, o tema proposto mobiliza a escala humana na avaliação dessa experiência do espaço.

A pertinência do tema - hospitalidade na fronteira entre edifício e cidade atua em duas perspectivas principais. A primeira de cunho ético. O movimento de acolhimento é um ato ético. “O ‘dar passagem' desloca o projeto para o plano ético da arquitetura" 38 . Para Derrida, as questões da hospitalidade são "fundações de uma ética da alteridade" 39 . Um espaço hospitaleiro em sua chegada, toma o outro como ponto de partida, de modo a se abrir e acolher o diferente. A segunda estaria associada a dimensão estética, relacionada aos componentes afetivos de habitar. $\mathrm{O}$ ato de refugiar pode ser associado à dimensão poética do projeto ${ }^{40}$. "As mudanças nos ambientes modificam o cérebro, e, consequentemente, mudam nosso comportamento. Ao planejar os ambientes em que vivemos, o projeto de arquitetura

${ }^{33}$ Gaston Bachelard - filósofo e poeta francês.

${ }^{34}$ BACHELARD, 1993, p.221.

${ }^{35}$ ZUMTHOR, 2009. p. 47.

${ }^{36}$ Ibidem., p. 43.

${ }^{37}$ FUÃO, Op. Cit, p.68.

${ }^{38}$ FUÃO, Op. Cit, p.44.

${ }^{39}$ Idem.

40 “A dimensão poética da arquitetura é uma qualidade mental, e a essência artística e mental da arquitetura emerge na experiência individual da obra.” PALLASMAA, 2018, p.104. 
muda nosso cérebro e nosso comportamento" ${ }^{41}$. A hospitalidade tem, dessa forma, um papel fundamental na construção do habitar.

Talvez uma das tarefas do arquiteto seja tonar hospitaleiro aquilo que é inóspito. Este tema induz, então, a repensar a arquitetura a partir de uma outra ótica, baseada na experiência humana do espaço. Ao tratar da hospitalidade na arquitetura, necessariamente trata-se do acolhimento na cidade. Em meio a cidades contemporâneas muitas vezes hostis, a reflexão acerca de uma arquitetura da hospitalidade se faz necessária.

O trabalho apresenta como objetivo geral a investigação do acolhimento do habitante na fronteira entre edifício e cidade. "Habitante", pois a leitura será realizada a partir da ótica da escala humana. A escolha do recorte de análise a partir das "fronteiras", por sua vez, se deve ao fato destas constituírem um limite com espessura, aspecto potencial na materialização de uma hospitalidade.

Esse objetivo geral traz, portanto, alguns objetivos específicos. O primeiro deles seria compreender como se dá a relação entre habitante e ambiente construído (I). Para isso, do ponto de vista teórico-metodológico, uma aproximação do campo fenomenológico da arquitetura se mostra pertinente quando se pretende explorar algo sob a ótica humana. Nesta pesquisa, a leitura fenomenológica se dará a partir de arquitetos que já abordaram as questões espaciais relativas à arquitetura a partir do campo da fenomenologia, como Pallasmaa e Christian Norberg-Schulz. Nesse sentido, será necessário clareza dos aspectos que influenciam a percepção ambiental para uma aproximação da experiência humana e da materialização do habitar. Isto permitirá a identificação das escalas da hospitalidade, tendo em vista que a experiência humana se dá de modo multissensorial. Além disso, fica evidente a necessidade de investigar e compreender o conceito de hospitalidade, tendo em vista seu desdobramento no âmbito arquitetônico (II). Torna-se possível aqui explorar a hospitalidade além da sua dimensão afetiva (relacionada à experiência do indivíduo), alcançando, assim, sua dimensão ética. Outro objetivo, relacionado ao recorte espacial, baseia-se na investigação das relações entre exterior e interior a partir do conceito de fronteira como espaço de mediação (III). Explora-se, nesse sentido, a dualidade entre esses espaços de modo a identificar estratégias de

\footnotetext{
${ }^{41}$ Segundo Gage, palestra AIA National Convention, San Diego, 2003 apud EBERHARD In: PALLASMAA; ROBINSON, 2015, p.135 (tradução da autora).
} 
abertura e isolamento entre eles. A partir dos objetivos citados, será possível, então, criar camadas de visualização do espaço. Isso possibilita traçar, desta maneira, o objetivo específico seguinte de identificação de estratégias em arquitetura (elementos, articulação entre eles e estímulos sensoriais) que operam na realização de um lugar da hospitalidade (IV). Esse processo permite que sejam traçadas categorias de análise da hospitalidade, relacionadas às escalas da hospitalidade identificadas. Reside aqui a intenção de identificar as dimensões que definem a hospitalidade no espaço habitado, que se expressam em diferentes escalas.

Foram identificados trabalhos que tratam dos temas da hospitalidade, da percepção ambiental e das fronteiras espaciais de modo isolado. Procura-se aqui, no entanto, estabelecer um ponto de contato entre esses conceitos, de modo que a ótica humana funcione como meio de leitura, a hospitalidade na arquitetura como objeto a ser investigado e as fronteiras como recorte, físico e social, potencial para o estudo proposto.

O método de pesquisa das questões mobilizadas se baseia, inicialmente, em uma investigação acerca dos conceitos mobilizados. A relação entre habitante e espaço é lida à luz de alguns autores principais relacionados a uma abordagem fenomenológica da arquitetura. A percepção humana é estudada a partir da obra do arquiteto Norberg-Schulz e do antropólogo Tim Ingold. A partir da percepção é possível compreender como se dá a experiência, lida a partir da obra de Steen Eiler Rasmussen. Norberg-Schulz explora também o conceito de lugar e o conceito de Habitar, estudado também a partir de Pallasmaa, que a partir de diversos autores tanto da filosofia, a arquitetura, a arte, entre outras disciplinas, sintetiza de forma precisa este conceito dentro do campo da arquitetura. A essência da arquitetura e a relação desta com aspectos da mente humana é estudada também por meio da obra de Pallasmaa. Zumthor compõe o referencial, por meio de suas colocações a respeito das atmosferas (entornos arquitetônicos - as coisas que nos rodeiam). Bachelard, a partir da filosofia, complementa a articulação, trazendo para a reflexão a questão da poética do espaço, tão pertinente quando pensamos em uma hospitalidade na arquitetura. Por meio desta leitura, é possível compreender aspectos da construção do lugar da hospitalidade.

O tema da hospitalidade, como conceito filosófico, é investigado aqui tendo como base a obra de Derrida. O filósofo não tem a arquitetura como foco principal ao abordar a questão da hospitalidade, que é explorada em sua obra de modo 
holístico. Para essa aproximação, o trabalho de Anne Dufourmantelle, junto a Derrida, acerca da hospitalidade, é fundamental. No que tange ao desdobramento em relação a arquitetura, tomou-se por base o trabalho de Dirce Eleonora Nigro Solis ${ }^{42}$ e Fernando Fuão ${ }^{43}$, que exploram "as formas do acolhimento na arquitetura". Neste ponto, destaca-se a intrínseca relação de afeto que se estabelece entre habitante e o lugar a partir dos gestos de hospitalidade. Para fomentar essa reflexão, foram exploradas as pesquisas de Fernando Espósito, acerca do afeto na arquitetura, e de Cristiane Duarte, acerca da Empatia Espacial. Por fim, para tratar da dualidade ética-estética, relativa ao conceito de hospitalidade, foi mobilizado também o trabalho de Brayner de Farias, a respeito das poéticas da hospitalidade.

$\mathrm{O}$ recorte escolhido para o desenvolvimento da pesquisa, a fronteira que constitui o espaço intermediário entre as construções, demanda trazer à discussão uma bibliografia orientada para este conceito, que permita a compreensão dos aspectos que a configuram. Para a definição do conceito de fronteira, parte-se incialmente das definições de Kevin Lynch e Jacobs. Adotam-se também as ideias presentes na obra de Herman Hertzberger e Gehl em uma tentativa de entendimento da fronteira, a partir da escala humana, como espaço de transição, além de Lineu Castello, na aproximação do conceito de urbanidade e sua relevância na construção do lugar da hospitalidade. Alguns autores relacionados à abordagem fenomenológica são retomados aqui para a construção do conceito de fronteira, a partir de uma abordagem poética. De modo complementar, tendo em vista os aspectos da construção do espaço urbano, articulam-se ainda os trabalhos de Ignasi Sola-Morales e Manuel Sola-Morales. Deriva daí uma questão importante que o trabalho deseja explorar: a fronteira como lugar da hospitalidade.

42 Dirce Eleonora Nigro Solis - professora associada do departamento de filosofia da Universidade do Estado do Rio de Janeiro (UERJ) e desenvolve pesquisa sobre o pensamento de Jacques Derrida desde os anos 19990.

${ }^{43}$ Fernando Fuão - arquiteto e professor da Faculdade de Arquitetura e do Programa de Pesquisa e Pós Graduação em Arquitetura da Universidade Federal do Rio Grande do Sul (PROPAR/UFRGS). Líder do grupo de pesquisa Arquitetura, Derrida e Interconexões (CNPq). 
O quadro (Figura 1) abaixo sintetiza o referencial teórico metodológico da pesquisa:

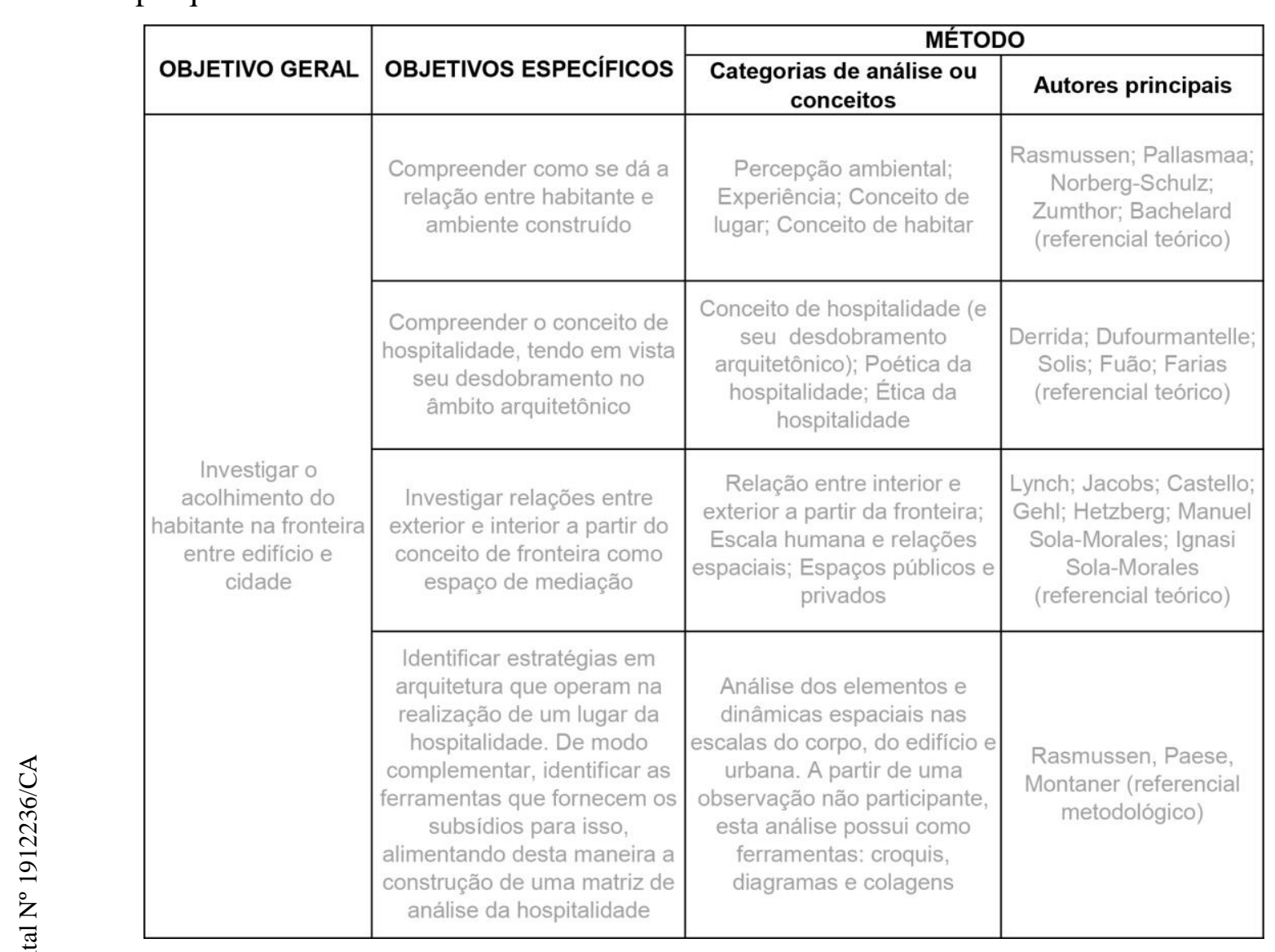

Figura 1: Quadro síntese referencial teórico-metodológico

Fonte: Elaborado pela autora

Essa fundamentação cria os subsídios e novas camadas de visualização do espaço habitado. A partir da vivência de obras construídas, o trabalho busca identificar estratégias arquitetônicas que operam nas relações de hospitalidade. Trata-se de uma tentativa de reconhecer, nas abordagens projetuais, gestos que geram acolhimento em arquitetura. O referencial teórico indica aspectos primordiais para compreensão das dimensões da hospitalidade, que operam em diferentes escalas, e em âmbito físico e mental. Três escalas principais são, então, traçadas: escala do corpo, escala do edifício e escala urbana. As ferramentas utilizadas para esta análise alimentam, por fim, uma matriz de análise da hospitalidade que sintetiza o processo de análise decorrente da investigação proposta. Esta matriz pode servir como ponto de partida para novas investigações acerca da hospitalidade na arquitetura. 
O referencial teórico-metodológico auxilia a construção das categorias de análise dos estudos de caso. A obra de Rasmussen é o referencial teóricometodológico na análise da experiência do espaço. Abarca-se aqui os estímulos sensoriais que constituem a experiência humana. Rasmussen explica, em Arquitetura vivenciada, como deve ser observado um espaço a partir de uma análise voltada para a experiência humana. Tem-se como referência também o trabalho de Montaner, Do diagrama às experiências, rumo a uma arquitetura de ação, no intuito de utilizar os diagramas como ferramenta para entender como as pessoas vivenciam o espaço. Por fim, o trabalho de Celma Paese, Cartografia da hospitalidade, serve como referência metodológica de leitura espacial por meio de cartografia subjetivo-afetivas.

Os capítulos 2, 3 e 4, apresentarão a investigação teórica acerca do "lugar da hospitalidade", do conceito de "hospitalidade" e acerca da "fronteira da hospitalidade", respectivamente. De forma paralela, serão apresentadas obras que, de algum modo, podem ser uma referência desde a perspectiva da hospitalidade na arquitetura. O capítulo 5 parte da memória de percursos realizados na cidade do Rio de Janeiro, onde espaços, extremamente conhecidos dentro do cotidiano carioca, são analisados a partir dos conceitos oriundos da investigação teórica. Seriam estes: Mureta da Urca e Praça São Salvador. A investigação visa fornecer, desta forma, novas possibilidades e os subsídios necessários para análise de obras arquitetônicas no âmbito de uma hospitalidade do lugar. A escolha desses espaços, além de relacionada ao caráter coletivo dos espaços, se justifica no fato de que se trata de lugares que operam de diferentes maneiras em cada escala da hospitalidade. Ambos os lugares possuem o banco como elemento da hospitalidade, que associado às demais dimensões do acolhimento, garantem a realização do lugar da hospitalidade dentro do cotidiano comum carioca. A opção por espaços que fazem parte da vivência habitual da cidade como estudo de caso em detrimento de obras emblemáticas da arquitetura, visa identificar gestos do acolhimento de modo a ressaltar a ideia aqui defendida de que a hospitalidade pode estar presente em qualquer lugar.

A análise se dá a partir de uma observação não participante, estruturada em um exercício de leitura do espaço, baseado em quatro eixos principais: (1) Investigação do contexto social-histórico-cultural do lugar, em um levantamento de dados acerca da construção de um lugar do acolhimento naquele contexto 
específico; (2) Figurar, por meio de croquis, importante ferramenta projetual, as possíveis vivências do espaço, identificando elementos importantes para a construção desse habitar e dimensionando-os; (3) Relacionar, por meio de diagramas, as escalas da hospitalidade aos gestos que geram acolhimento no espaço; (4) Confecção de colagens que buscam reconfigurar memórias de vivências identificadas naqueles lugares.

Dessa forma, a presente pesquisa parte de projetos mais emblemáticos e conhecidos, identificando pontualmente gestos que constroem lugares da hospitalidade na cidade, para chegar, por fim, em uma análise de estudos de caso de espaços comuns, pertencentes ao cotidiano carioca. Esta postura reafirma a ideia de que a hospitalidade está em tudo e não depende exclusivamente grandes projetos, mas pode estar inclusive no banco de uma praça. Deste modo, a análise procura se ater mais aos gestos de hospitalidade presentes na vivência da cidade, sejam eles decorrentes de obras notórias ou não.

A investigação explora a construção do lugar da hospitalidade, por meio variadas estratégias de projeto. Chão, cobertura, porta e parede são alguns dos elementos próprios da arquitetura que participam da configuração da relação entre edifício e entorno imediato. As relações entre cheios e vazios, constituídas a partir das cavidades do espaço, os efeitos de luz e sombra, as texturas e a dimensão do corpo são alguns dos aspectos que constituem a experiência do espaço, tendo em vista uma percepção multissensorial da hospitalidade. As interações socioculturais estimuladas no espaço dessas fronteiras revelam a vivência humana do espaço. A hipótese aqui colocada é de que a hospitalidade opera em variadas escalas, de modo que cada qual abarca questões específicas relativas ao acolhimento.

Para esse estudo, espaços de uso coletivo construídos se mostram pertinentes, pois pressupõem a convivência entre diferentes pessoas devido ao caráter público. São espaços normalmente diretamente relacionados ao contexto urbano e por isso parecem adequados a uma observação a partir da ótica da hospitalidade. A respeito do coletivo, vale pontuar o argumento de M. Sola-Morales acerca do conceito de urbanizar o privado. A ideia é tratar de um patrimônio coletivo que absorve o privado na esfera do público. Para ele, “a boa cidade é aquela onde edifícios 
particulares [...] são elementos públicos e carregam significados e valores sociais além de si mesmos, e esse é o modo de ser urbano deles" ${ }^{\$ 4}$.

A contribuição da pesquisa pode ser atribuída à matriz de análise que resulta da investigação teórica e análise dos estudos de caso, pois essa matriz pode servir como guia para outras análises da hospitalidade. Outra contribuição que a pesquisa procura suscitar encontra-se atrelada às escalas da hospitalidade e à caracterização destas. Ao propor uma investigação que parte da construção do lugar da hospitalidade, visando compreender as relações entre habitante e ambiente construído, propõe-se que a hospitalidade se dê por meio de diferentes estratégias que operam em diferentes escalas. Desde a escala do corpo, passando pela escala do edifício, até a escala urbana. Assim se dispõe da hospitalidade na arquitetura. 


\section{O lugar da hospitalidade: a relação entre espaço e habitar}

\section{1.}

\section{Da percepção à experiência}

Para entender como se dá a relação entre indivíduo e espaço, é necessário compreender alguns aspectos relativos à percepção ambiental humana. $\mathrm{O}$ modo como percebemos o ambiente será fundamental, então, para entendermos parte da construção da experiência espacial e a partir disso, consequentemente, compreender aspectos relativos à hospitalidade que um espaço pode demonstrar em relação ao indivíduo.

Ingold $^{45}$ afirma que a percepção envolve movimento, tratando-se de um modo de ação e não um pré-requisito para esta. Ele aborda a percepção ambiental como "um processo ativo e exploratório de captação de informações" 46 . Entendendo a percepção como modo de ação, o que percebemos deve ser uma "função direta de como agimos" $" 47$ no espaço. "Poderíamos dizer que a arquitetura também é um verbo, uma vez que sua verdadeira essência sempre é um convite à ação. É essa tendência de parecer um verbo em direção à busca e exploração ativas que une a arquitetura e a mente humana" 48 .

Nesse sentido, indaga-se aqui como o meio suscita esta ação. O que molda ou influencia a forma como agimos no espaço? Como a arquitetura atua nesse processo de sedução do habitante na vivência do espaço? O estímulo aos diferentes sentidos

\footnotetext{
45 Tim Ingold - Antropólogo britânico.

${ }^{46}$ INGOLD, 2000, p.166 (tradução da autora).

${ }^{47}$ Idem.

${ }^{48}$ PALLASMAA, 2018, p.110.
} 
pode contribuir nesse processo. "O psicólogo James. J. Gibson considera os sentidos como mecanismos de busca agressiva, e não como meros receptores passivos" $"$.

Cabe pontuar aqui, algumas questões levantadas por Norberg-Schulz, a respeito da percepção, em Intenciones en arquitectura. Ele aponta que "pessoas diferentes experimentam o mesmo entorno de maneira similar e diferente" ${ }^{50}$. Seria, nesse sentido, ingênuo considerar que o mundo é semelhante para todos. "O mundo não é o que parece imediatamente para nós. [...] Percebemos todas as situações das quais participamos em relação às nossas próprias experiências prévias" ${ }^{51}$. Isto significa que a experiência espacial alude a diferentes representações (individuais) de um mesmo mundo. A arquitetura nos toca de diferentes maneiras e contribui, dessa forma, para "proporcionar um horizonte de entendimento de nossa condição existencial” ${ }^{\prime 2}$. Além de ativar, ela reforça nosso senso de identidade. Nossa experiência é sempre individual e única. "A arquitetura parece sempre estar se dirigindo a cada um de nós individualmente" ${ }^{, 53}$.

Pallasmaa, a partir da filosofia de Maurice Merleau-Ponty, destaca o corpo como o centro do mundo das experiências. "Nossos corpos e movimentos estão em constante interação com o ambiente" ${ }^{, 54}$. A percepção do corpo, junto à imagem inconsciente do mundo, constrói a experiência humana do espaço. O corpo, de acordo com Ingold, não seria objeto nem instrumento, mas o "sujeito da percepção" ${ }^{\text {55 }}$. Isto sugere uma experiência corporificada ${ }^{56}$ da arquitetura. Estudos revelaram que os atos de perceber e imaginar ocorrem nas mesmas áreas do cérebro e que consequentemente, esses atos estão intimamente relacionados ${ }^{57}$. Logo, o ato de perceber é também um ato de criação.

"Toda experiência comovente com a arquitetura é multissensorial." 58 Pallasmaa, em Os olhos da pele, explora a colaboração entre os sentidos no processo da percepção. Para ele, poderíamos considerar o tato como sentido

\footnotetext{
${ }^{49}$ PALLASMAA, 2011, p.39.

${ }^{50}$ NORBERG-SCHULZ, 2001, p.22. (tradução da autora).

${ }^{51}$ Ibidem, p.34

52 PALLASMAA, 2017, p.75.

${ }^{53}$ PALLASMAA, 2018, p.113.

${ }^{54}$ PALLASMAA, 2011, p.38.

${ }^{55}$ INGOLD, T. Op. Cit. p. 169.

${ }^{56}$ PALLASMAA, 2018, p.112.

${ }^{57}$ PALLASMAA, 2015, p.68-69 (tradução da autora).

${ }^{58}$ PALLASMAA, 2011, p.39.
} 
inconsciente da visão. Isto porque a visão desvinculada do tato não fornece a noção completa do espaço. O tato é responsável por sentir o peso, a resistência, a forma tridimensional, a solidez a protuberância ${ }^{59}$. Todos os sentidos, incluindo a visão, seriam, então, extensões do tato. Uma intenção hospitaleira da arquitetura frente ao habitante pode abarcar, portanto, o estímulo a diferentes sentidos, pois se revela atenta à experiência humana prazerosa do espaço. "É evidente que uma arquitetura 'que intensifique a vida' deva provocar todos os sentidos simultaneamente e fundir nossa imagem de indivíduos com nossa experiência de mundo"60.

Sob este aspecto, vale comentar a essência multissensorial da experiência, discorrida por Pallasmaa. Embora, a princípio, pareça que o campo visual possa dar conta de compreender a arquitetura, na experiência de um ambiente confrontamos com todos os nossos sentidos simultaneamente, o vivenciando como parte de nosso mundo existencial. "Bachelard chama essa interação sensorial fundida de 'a polifonia dos sentidos" "61. A propósito da hegemonia da visão, Pallasmaa argumenta que "o senso de visão direcional nos torna observadores alheios, enquanto os sensos onidirecionais e envolventes da audição, tato, olfato e inclusive paladar nos tornam íntimos e participantes" ${ }^{\circ 2}$.

No que concerne à abordagem poética e fenomenológica, Pallasmaa aponta que se tem consolidado, durante as últimas décadas, uma abordagem experiencial, baseada nos encontros fenomenológicos e nas experiências com os edifícios e seus $\operatorname{contextos}^{63}$. Trata-se de uma tentativa de superação da leitura puramente visual da arquitetura em busca da experiência multissensorial inerente a ela.

Intuir a experiência do habitante pode ser uma das tarefas mais desafiadoras e valiosas do ato de projetar em arquitetura. Por isso, compreender os aspectos da percepção humana contribuem para esta aproximação.

As percepções não são experiências, uma vez que são meros registros de estímulo sem contextualização, julgamento e significado. As percepções dos sentidos interagem com a memória e a imaginação para constituir uma experiência total integrada com distintas conexões e significados. ${ }^{64}$

\footnotetext{
${ }^{59}$ Idem

${ }^{60}$ PALLASMAA, 2011, p.11

${ }^{61}$ PALLASMAA, 2018, p. 57

${ }^{62}$ Ibidem, p. 111

${ }^{63}$ Ibidem, p.111

${ }^{64}$ Ibidem, p. 114
} 
Além disso, vale pontuar que a experiência é um dado subjetivo que se relaciona diretamente aos sentimentos humanos. "A experiencia significa aprender a partir da própria vivência. Experenciar é aprender; significa atuar sobre um dado e criar a partir dele" ${ }^{\prime 65}$. A partir da interação com o contexto, criam-se alguns sentimentos que compõem a experiência sensível do lugar. Os sentimentos se constituem em cada ser humano a partir de uma sucessão de sensações distintas em interação com a memória. Dessa forma, sentimento e pensamento se complementam em um processo de conhecer ${ }^{66}$, inerente à experiência humana.

Rasmussen explora a vivência da arquitetura a partir de uma análise de como percebemos as coisas que nos cercam. Por meio de sua abordagem é possível relacionar diretamente o ato de projetar do arquiteto com as questões relativas ao conceito de hospitalidade. A relação entre hóspede e hospedeiro pode ser comparada a relação entre habitante e arquiteto. Hospitalidade envolve receber e cuidar do outro.

O arquiteto é uma espécie de produtor teatral, o homem que planeja o cenário para nossas vidas. Inúmeras circunstâncias dependem da maneira como ele organiza esse cenário para nós. Quando suas intenções são bem-sucedidas, ele é o anfitrião perfeito que oferece todo o conforto a seus convidados, de modo que viver com ele seja uma experiência feliz. ${ }^{67}$

Rasmussen pontua também que os elementos da arquitetura $^{68}$ são algumas das coisas que o arquiteto pode colocar em jogo na concepção do espaço. $\mathrm{O}$ autor explora os mais diversos âmbitos, revelando que experimentar a arquitetura significa entender os mínimos detalhes, por meio de atitudes como: observar como o indivíduo é naturalmente conduzido entre cômodos, estar ciente dos efeitos texturais, entender como o som age no espaço, com seus ecos e reverberações, desvendar como o ambiente está exposto a luz do sol, dentre outras leituras possíveis.

Rasmussen propõe que a arquitetura, ao invés de trabalhar com os sólidos de uma construção, possa trabalhar com o "espaço vazio - a cavidade - entre os sólidos e considerar a formação desse espaço o verdadeiro significado da arquitetura." 69 Essa abordagem garante um enfoque sobre o espaço arquitetônico formado, em

\footnotetext{
65 TUAN, 2012, p.10.

${ }^{66}$ Ibidem, p.11.

${ }^{67}$ RASMUSSEN, 2015, p.9.

${ }^{68}$ Ibidem, p. 27.

${ }^{69}$ Ibidem, p.46.
} 
detrimento da estrutura que o origina. "A arquitetura é uma grande escultura escavada, em cujo interior o homem penetra e caminha" ${ }^{\text {"70 }}$. Esse aspecto parece estar relacionado ao caráter hospitaleiro de um ambiente, pois constitui o vazio no qual se dá a experiência humana, de modo que se pode considerar que as cavidades do espaço, de algum modo, recepcionam e acomodam o habitante.

A respeito dos efeitos texturais, Rasmussen aponta que "os materiais são julgados não só por sua aparência superficial, mas também de acordo com sua dureza e condutividade térmica". Tornar a superfície agradável ao tato pode ser uma estratégia que compõe a hospitalidade atribuída a arquitetura.

De modo complementar, a maneira como a luz incide sobre a superfície, lateral ou diretamente, afeta a percepção humana sobre a textura e o relevo. Rasmussen chama a atenção para as diferentes impressões que o espaço pode causar mediante a localização e dimensionamento das aberturas.

"Portanto, entender a arquitetura não é o mesmo que determinar o estilo de um edifício por determinados recursos externos. Não basta ver a arquitetura; você deve experimentar isso"71. Reside aqui a construção do espaço voltado para o habitante em arquitetura: uma leitura holística da experiência humana do espaço.

\footnotetext{
${ }^{70}$ ZEVI, 2009, p.17.
}

${ }^{71}$ Ibidem, p.32. 


\section{2.}

\section{O conceito de lugar}

$\mathrm{Na}$ investigação acerca da relação entre sujeito e ambiente construído, o entendimento do conceito de lugar mostra-se necessário. Por espaço, entende-se "Distância entre dois pontos, ou área ou volume entre limites determinados" paralelamente, a respeito do termo lugar, entende-se "Espaço ocupado"73. Em outras palavras, ao abordar o lugar, trazemos para a questão o elemento humano. Genius Loci Towards a Phenomenology of Architecture é uma sequência do trabalho conceitual presente em Intentions in Architecture ${ }^{74}$, na qual Noberg-Schulz continua a busca pelo entendimento concreto do ambiente. Nesta obra, ele afirma que o lugar é evidentemente uma parte integrante da existência humana e o define como fenômeno:

O que queremos dizer com a palavra 'lugar'? Obviamente, queremos dizer algo que significa mais do que uma localização abstrata. Queremos dizer um total composto de coisas concretas com substância material, forma, textura e cor. Juntas, essas coisas determinam um 'caráter ambiental', que é a essência do lugar. Em geral, um lugar é dado como um personagem ou 'atmosfera'. Um lugar é, portanto, um fenômeno qualitativo, 'total', que não podemos reduzir a nenhuma de suas propriedades, como relações espaciais, sem perder sua natureza concreta de vista. ${ }^{75}$

Norberg-Schulz explora ainda o termo espaço, pontuando que "podemos distinguir [espaço] entre dois usos: espaço como geometria tridimensional e espaço como campo perceptivo"76.

Essa reflexão acerca do lugar coloca o espaço como um sistema de lugares ${ }^{77}$. Como consequência, "cidades e casas consistem em uma infinidade de lugares particulares"78, pois ações diferentes demandam ambientes diversos para que ocorram de modo satisfatório.

Tal como apontado por Norberg-Schulz, o lugar seria um ponto de partida bem como o objetivo de uma investigação estrutural, alegando que "no início, o lugar se apresenta como um dado, espontaneamente vivido como uma totalidade e,

${ }^{72}$ FERREIRA, 1999, p.809.

${ }^{73}$ Ibidem, p. 1239.

${ }^{74}$ Primeira publicação de Intentions in Architecture foi em 1962, enquanto a de Genius Loci Towards a Phenomenology of Architecture foi em 1980.

${ }^{75}$ NOBERG-SCHULZ, 1980, p.8 (tradução da autora).

76 Ibidem, p.11 (tradução da autora).

${ }^{77}$ PORTOGHESI apud NOBERG-SCHULZ, 1980, p.12 (tradução da autora).

${ }^{78}$ NOBERG-SCHULZ, 1980, p.8 (tradução da autora). 
ao fim ele aparece como um mundo estruturado, iluminado pela análise dos aspectos do espaço e do caráter"79.

Parece válido considerar aqui a relação entre lugar, habitante e arquiteto a partir da ótica do afeto. Primeiramente, “o contexto não é um cenário, nem um telão de fundo, nem uma explicação, contexto e obra de arquitetura configuram juntos a noção de lugar" ${ }^{\prime 0}$. O arquiteto é responsável por articular a relação entre habitante e contexto, entre sociedade e lugar, a partir de suas próprias percepções e experiências. O conceito do afeto, de acordo com Espósito, atua, portanto, em duas vertentes principais: o afeto referente ao ato projetual (que decorre das impressões do arquiteto diante do contexto - afeição - e da expressão desse sentimento - afeto - por meio do projeto) e o afeto referente ao ato de habitar (associado às relações afetivas do habitante em relação a um lugar). "Um arquiteto, portanto, não só projeta um objeto, mas também está projetando uma série de reações do habitante ao que projeta, a partir de suas próprias vivências, que são suas próprias impressões sensitivas e expressões emotivas" $"$. A hospitalidade está diretamente relacionada a essa relação de afeto com o lugar, que se estabelece a partir do projeto arquitetônico. De acordo com Yi-Fu Tuan, existe um "elo afetivo entre a pessoa e o lugar ou ambiente construído" 82 . Ainda segundo o autor, a afeição é em parte "resultado de experiências íntimas e aconchegantes" ${ }^{\text {83. }}$.

Em uma reflexão, realizada em conferência, Zumthor explora a capacidade dos edifícios e o seu meio de oferecer as pessoas um excelente lugar para o desenvolvimento de suas vidas. Ele desenvolve, então, o conceito de atmosfera. Vale pontuar aqui a colocação de Norberg-Schulz a respeito da estrutura do lugar. Segundo o arquiteto, essa estrutura seria resultado da relação entre espaço e caráter, onde espaço indica a organização tridimensional e caráter denota a atmosfera, que é a propriedade mais abrangente de um lugar. Rasmussen faz um contraponto entre imagem e atmosfera, apontando que a vivência efetiva do ambiente construído nos aproxima da atmosfera desse ambiente, em detrimento de uma impressão relativa a este exclusivamente visual. A atmosfera de Zumthor baseia-se, então, em um ambiente, uma disposição do espaço construído que comunica com seus habitantes.

\footnotetext{
${ }^{79}$ NOBERG-SCHULZ, 1980, p.18 (tradução da autora).

${ }^{80}$ ESPÓSITO, 2012, p.9 (tradução da autora).

${ }^{81}$ Ibidem, p.11.

82 TUAN, 2012, p.5.

${ }^{83}$ TUAN, 2012, p.153.
} 
Este conceito relativo ao lugar, está diretamente ligado ao da hospitalidade, pois trata de algum modo da conformação de lugares que "que cuidam do homem, que o deixam viver bem" $"$.

Para Zumthor, qualidade arquitetônica significa ser tocado por uma obra. O que garante, no entanto, que uma obra toque seus habitantes? Para ele, isso se deve à chamada atmosfera. "A atmosfera comunica com a nossa percepção emocional" Entre as coisas que nos tocam estariam o ar, ruídos, sons, cores, presenças materiais, texturas e formas. Zumthor desenvolve, então, alguns pontos que constroem a atmosfera arquitetônica.

O primeiro ponto seria o "o corpo da arquitetura". Este ponto trata da presença material dos objetos de uma construção. A junção dos materiais cria o espaço, criando um corpo quase literalmente. O segundo ponto abordado é a "consonância dos materiais". Zumthor explica que os materiais soam em conjunto e irradiam. É desta composição que nasce uma experiência única. Os materiais são apresentados em sua infinitude, por apresentarem inúmeras possibilidades, inclusive por meio da exposição a luz. O terceiro ponto é o som do espaço. Para o autor, cada espaço funciona como um instrumento que amplia e transmite sons. O quarto ponto explora a temperatura do espaço. Esta condição depende diretamente dos materiais escolhidos. Para Zumthor, "esta tempertatura é física e provavelmente também psíquica. O que vejo, o que sinto e o que toco... mesmo com os pés"86. O quinto ponto foi denominado "as coisas que me rodeiam". Aqui ele fala das coisas que ocupam o espaço e relata uma sensação de cuidado a respeito. $\mathrm{O}$ sexto ponto seria "entre a serenidade e a sedução". Zumthor aborda o movimento no espaço. Neste ponto, exalta um vaguear livre, não conduzido, mas que se dá por meio da sedução. "Seduzir - afirma Derrida - é prometer alguma coisa - um sentido por

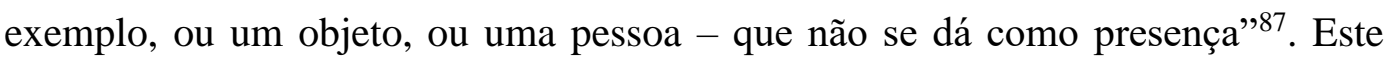
aspecto alude ao que desperta a atenção do habitante. Trata-se de conduzir o sujeito no espaço, de forma não didática, mas natural. O sétimo ponto das atmosferas trata da "tensão entre interior e exterior". Este ponto ressalta o jogo estre ambientes privativos e públicos, por meio dos seus graus de desvelamento. O oitavo ponto foi

\footnotetext{
${ }^{84}$ ZUMTHOR, 2009, p.7.

${ }^{85}$ Ibidem, p.13.

${ }^{86}$ Ibidem, p.35.

${ }^{87}$ HIGINO, 2010, p.14.
} 
intitulado "degraus da intimidade". Relaciona-se com a dimensão e peso da obra em relação a escapa do corpo. Este aspecto promove sensações variadas na vivência do espaço. O nono e último ponto de Zumthor é chamado "a luz sobre as coisas". Este ponto ressalta a importância de observarmos onde está a luz e de que modo ela incide sobre a superfície. Importante perceber também as sombras geradas e como os materiais refletem a luz. "A luz é de importância decisiva para sentirmos a arquitetura" ${ }^{8}$, pois, tal como apontado por Rasmussen o caráter do espaço muda completamente de acordo com o modo pelo qual a luz natural incide sobre uma superfície do espaço. Pallasmaa aborda a tatialidade e materialidade da luz, ressaltando que a luz tende a estar ausente experimental e emocionalmente até que ela seja contida pelo espaço, ou seja, "concretizada pela matéria que ela ilumina" 89 .

A luz é a "doadora de todas as presenças", mas "o que quer que seja feito de luz lança uma sombra". "Nosso trabalho é sobre sombra". Para cumprir sua tarefa, a luz precisa, portanto, de material e estrutura. Assim, Kahn diz: "O sol nunca soube o quão magnífico era até atingir a lateral de um edifício". ${ }^{90}$

A pertinência da atmosfera desenvolvida por Zumthor em nove pontos reside na caracterização de um lugar poético que acolhe o habitante em variadas nuances. A hospitalidade do espaço, certamente, demanda a criação de atmosferas que nos tocam.

Ficam evidentes as transversalidades inerentes às abordagens dos autores aqui citados. Este parece ser um aspecto importante que subsidia a investigação em torno da construção do lugar em arquitetura.

“O propósito existencial do construir (arquitetura) é, portanto, fazer um sítio tornar-se lugar, isto é, revelar os significados potenciais presentes no ambiente dado"91. Arquitetura significa então, criar lugares significativos a partir do reconhecimento do espírito do lugar, ajudando, assim, o homem a habitar. "O lugar é a manifestação concreta do habitar do homem, e sua identidade depende do seu pertencimento ao lugar" ${ }^{\prime 92}$. É por meio da experiência de um ambiente significativo que o homem se orienta e se identifica com ele. "Isso implica que os espaços onde a vida ocorre são lugares, no verdadeiro sentido da palavra"93.

\footnotetext{
${ }^{88}$ RASMUSSEN, 2015, p.193.

${ }^{89}$ PALLASMAA, 2018, p.59.

${ }^{90}$ NORBERG-SCHULZ, 1979, p.32 (tradução da autora).

${ }^{91}$ NOBERG-SCHULZ, 1980, p.18 (tradução da autora).

${ }^{92}$ Ibidem, p.9

${ }^{93}$ Ibidem, p.5
} 
De acordo com Tuan, espaços são transformados em lugares a partir do momento que lhes são atribuídos afetos. Essa aproximação desde a percepção ambiental na direção da construção da experiência humana, que busca transformar o espaço em lugar, nos permite chegar ao ponto principal da relação entre homem e ambiente físico: o habitar. 


\section{3.}

\section{A essência do habitar}

A palavra habitar é usada para indicar a relação total entre homem e lugar. Em qualquer tipo de arquitetura, independentemente de sua função, o homem pode habitar, pois o ato de habitar está associado a um modo de se relacionar com o mundo $^{94}$ e não com um programa arquitetônico. Habitar é geralmente compreendido, então, como essa relação humana com o lugar e possui, dessa forma, significados existenciais importantes. Heidegger explora algumas relações linguísticas para mostrar que "habitar significa estar em paz em um lugar protegido"95.

A questão do habitar toca o campo da mente humana. A arquitetura como materialização desse habitar é território para reflexões acerca do campo psíquico. “Como arquitetos, nós não projetamos edifícios primordialmente como objetos físicos, mas como as imagens e os sentimentos das pessoas que os habitam"96. O afastamento dessa busca pelo habitar humano é examinado por Pallasmaa no ensaio A geometria do sentimento: um olhar sobre a fenomenologia da arquitetura $^{97}$, na qual ele explora "a relação entre a forma arquitetônica e o modo pela qual ela é experimentada"98. Pallasmaa argumenta que o planejamento se transformou em uma espécie de jogo de formas, de modo que a experiência real da arquitetura tem sido negligenciada.

Nesse ensaio, Pallasmaa explora ainda o que ele chama de "sentimentos primordiais da arquitetura" ${ }^{99}$, no qual lista experiências relacionadas a esses sentimentos básicos proporcionados. Interessam aqui algumas deles, tendo em vista o recorte de análise estabelecido pela presente pesquisa.

A primeira delas seria "ter um teto em cima da cabeça, estar abrigado e à sombra" ${ }^{100}$. Esta experiência por ele listada, levanta o questionamento, pertinente a investigação, acerca dos componentes da arquitetura que impactam a experiência

${ }^{94}$ PALLASMAA, 2017, p.7.

${ }^{95}$ NOBERG-SCHULZ, 1980, p.22 (tradução da autora).

${ }^{96}$ PALLASMAA, 1986. In: NESBITT, 2008, p.485.

${ }^{97}$ Título original: The Geometry of Feeling: a Look at the Phenomenology of Architecture. Extraído de Sakala: Nordic Journal of Architecture and Art - 4, jun. 1986.

${ }^{98}$ PALLASMAA, Op.Cit, p.483.

${ }^{99}$ Ibidem, p.486.

${ }^{100}$ Ibidem, p.487. 
humana do espaço e contribuem para a sensação de acolhimento da arquitetura. Trata-se da escala do edifício como uma escala da hospitalidade, na qual os elementos da arquitetura operam de modo a estabelecer uma relação de recepção frente ao indivíduo. A arquitetura "confina o espaço para que possamos habitar nele, cria a estrutura em torno de nossas vidas"101. O sentimento do habitante despertado pelos elementos que compõem o lugar pode ser relacionado às cavidades do espaço exploradas por Rasmussen. O caráter do espaço não construído, ou seja, vazio, é delimitado por essa estrutura composta pelos elementos que compõem o espaço construído.

Outra experiência listada pelo autor, que reforça a adequação do recorte escolhido para esta pesquisa, seria "entrar na casa, atravessar a porta, cruzar a fronteira entre interior e exterior" ${ }^{\prime 102}$. Esta experiência provoca uma reflexão acerca da alternância entre interior e exterior, ou seja, de como a arquitetura estabelece esta transição em relação ao seu entorno imediato. Aqui encontramos a escala urbana também como escala da hospitalidade. Zumthor, como apontado anteriormente, atribui à “tensão entre interior e exterior" a constituição da chamada atmosfera, junto a alguns outros fatores. Essa atmosfera comunica com a percepção emocional humana, corroborando com a ideia de Pallasmaa de que a transição entre o interior de uma construção e seu entorno corresponde a uma experiência que revela um sentimento intrínseco a arquitetura.

Por fim, a terceira experiência listada, e pertinente às relações aqui estudadas, seria "deparar com a luz ou com a escuridão que domina o espaço, o espaço de luz" ${ }^{\prime 103}$. Aqui se aborda de algum modo a questão da percepção desenvolvida anteriormente. Destaca-se nesse ponto mais uma escala da hospitalidade, a escala do corpo. Essa experiência reconhece aspectos já sinalizados, referentes a conformação do lugar. A "consonância dos materiais" e a "luz sobre as coisas", relativas à atmosfera exposta por Zumthor concatenam-se com o sentimento descrito por Pallasmaa. Rasmussen também valoriza esta escala do corpo ao explorar os efeitos texturais e o modo como a luz incide sobre a arquitetura.

As questões elaboradas por esses autores convergem para a ideia de que a arquitetura se comunica com o habitante em variadas escalas. Poderíamos dizer,

\footnotetext{
${ }^{101}$ RASMUSSEN, 2015, p.8.

102 PALLASMAA, 1986. In: NESBITT, 2008, p.487.

${ }^{103}$ Idem.
} 
então, que as três escalas identificadas nas experiências listadas por Pallasmaa, operam simultaneamente, de modo integrado, na construção de uma hospitalidade da arquitetura. "Na experiência, descobrimos uma combinação do biológico e do cultural, do coletivo e do intelectual, do consciente e do inconsciente, do analítico e do emocional, do mental e do físico"104

A articulação entre os conceitos explorados expõe variadas questões relativas à vivência do espaço arquitetônico. "As experiências tocantes da arquitetura surgem de memórias e significados bioculturais secretos e pré-conscientes [...]. Essas características poderiam ser chamadas de "essências arquitetônicas""105. E é por meio dessa essência poética que a pesquisa pretende compreender a hospitalidade na arquitetura.

Em resumo, habitar um espaço passa por dois âmbitos coextensivos. O primeiro deles seria o da percepção ambiental. Este seria relativo ao corpo e a mente. Por meio dele, as informações referentes à percepção interagem com a mente e constroem o que chamamos de experiência espacial. Estímulos multissensoriais, que extrapolam o campo da visão são fundamentais para que isso ocorra. O segundo âmbito, que decorre do primeiro, construindo o chamado lugar. Daqui extraímos os elementos (materiais) arquitetônicos que compõem o espaço. Esse lugar possui significado para seu habitante, extrapolando, deste modo, sua dimensão física.

$\mathrm{Na}$ interação entre edifício e o contexto em que foi construído, podemos identificar uma fronteira, lida aqui como espaço entre, potencial para as relações de hospitalidade entre habitante e espaço. Habitar essa fronteira, significaria então, percebê-la, de modo a vivenciá-la, a partir do lugar construído.

Ler a hospitalidade nessa fronteira, perpassa, portanto, três escalas (nomeadas aqui escalas da hospitalidade): a escala do corpo, que percebe o espaço e delimita a experiência dessa fronteira; a escala do edifício, que faz uso dos elementos da arquitetura para receber o habitante; e a escala urbana, que articula o edifício a um contexto inerente, incentivando ou não a interação social.

\footnotetext{
${ }^{104}$ PALLASMAA, 2008, p.488.
}

105 PALLASMAA, 2018, p.8. 
O diagrama conceitual a seguir (Figura 2) sintetiza tais relações:

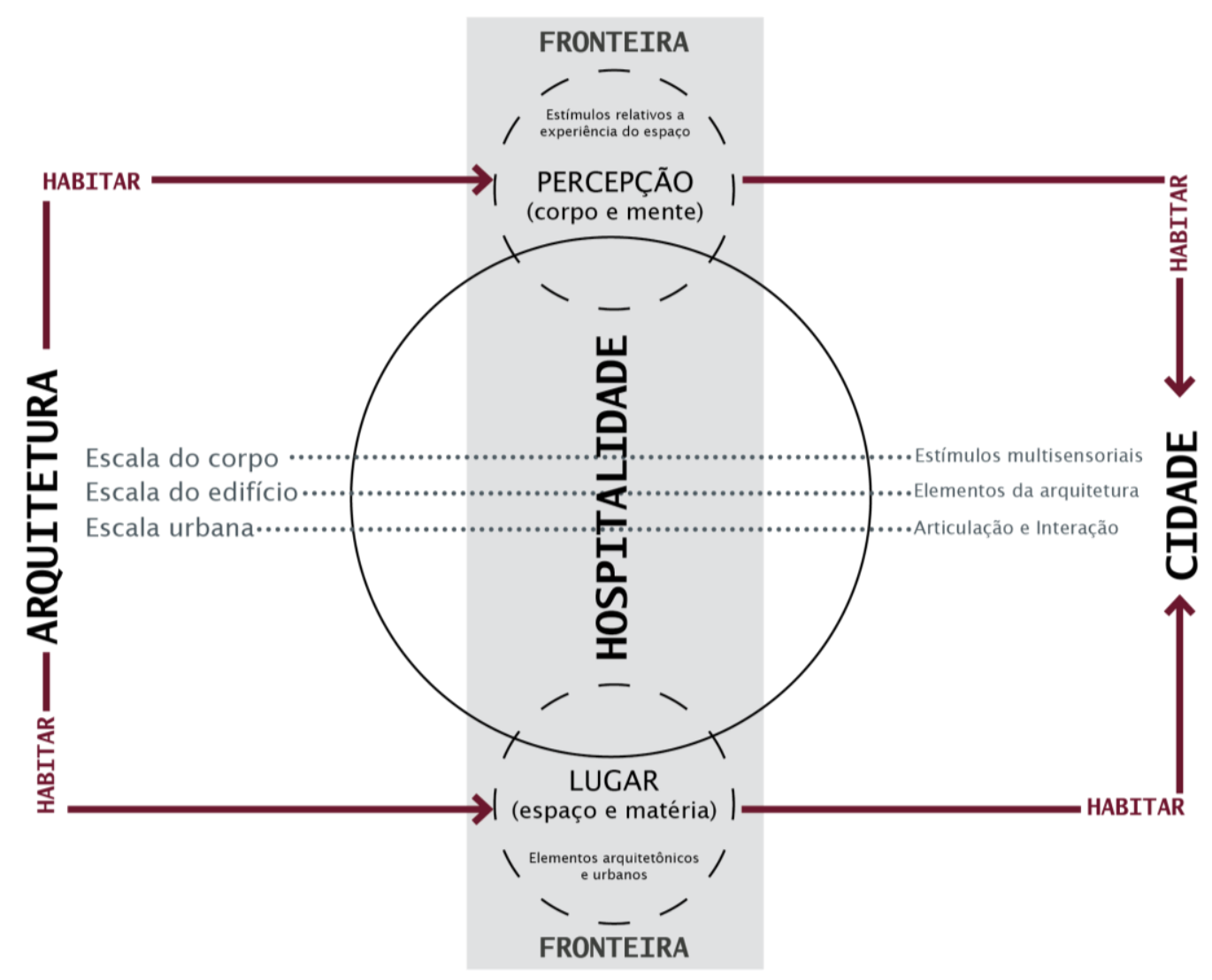

Figura 2: Diagrama conceitual

Fonte: Elaborado pela autora

É importante mencionar neste ponto, que as escalas da hospitalidade precisam ser entendidas como escalas coextensivas. Um mesmo gesto, ou estratégia de projeto opera em mais de uma escala, o que acaba por corroborar a premissa de que a arquitetura é uma disciplina multiescalar. A qualidade da intervenção depende justamente dessa capacidade de transitar entre escalas de modo a garantir o acolhimento do habitante.

Essa abordagem nos apresenta a essência artística e mental da arquitetura que emerge na experiência individual de uma obra ${ }^{106}$. A dimensão poética revela-se uma dimensão mental. Um aspecto importante formulado por Pallasmaa é que a 
arquitetura ao criar estruturas para a percepção, experiência e entendimento, em vez de ser o produto final, assume um papel essencialmente mediador ${ }^{107}$.

De acordo com Norberg-Schulz, o ambiente influencia os seres humanos e isso implica que o objetivo da arquitetura transcende a questão do funcionalismo ${ }^{108}$. Enfatiza, ainda, que "não existem 'tipos' de arquitetura diferentes, mas apenas situações diferentes que requerem soluções diferentes para satisfazer as necessidades físicas e psíquicas do homem" ${ }^{109}$. Estaria aqui a essência humana da arquitetura. Explorar a esfera psíquica releva-se assim propício.

Pallasmaa sinaliza que "a tarefa da arquitetura se estende além de suas propriedades materiais, funcionais e mensuráveis - e inclusive além da estética até a esfera mental e existencial da vida"110. $\mathrm{O}$ abrigo que a arquitetura fornece ao habitante, tão pertinente ao objeto de estudo da hospitalidade, não é apenas físico, pois o edifício abriga também as memórias e a mente do sujeito. "Os edifícios mediam a relação entre o mundo e nossa consciência, internalizando o mundo e exteriorizando a mente" ${ }^{" 11}$. Enfim, partindo de uma leitura do ambiente a partir da ótica do habitante, é evidentemente necessário compreender melhor o ser humano e suas propriedades mentais. "Arquitetura é espaço mental construído" ${ }^{112}$. Habitar, em essência, parece estar vinculado na interseção de dois aspectos complementares de nossas vidas: "o modo como organizamos o espaço e os edifícios abordam simultaneamente nossa necessidade de habitação física e nossa necessidade de significado"113. A arquitetura se apresenta como uma maneira humana de se relacionar com o mundo que a cerca.

A interdisciplinaridade é conveniente ao tratar dessas questões humanas. Diversas disciplinas, como biologia, psicologia, neurociência cognitiva e fenomenologia podem auxiliar no desvelamento das propriedades mentais aplicadas ao espaço. A neurociência e a arquitetura se cruzam na compreensão e no compromisso em relação a figura do ser humano:

O ser humano corporificado, um ser que só pode existir em relacionamento; relacionamento com os lugares onde habitamos, um com o outro, com o mundo. As

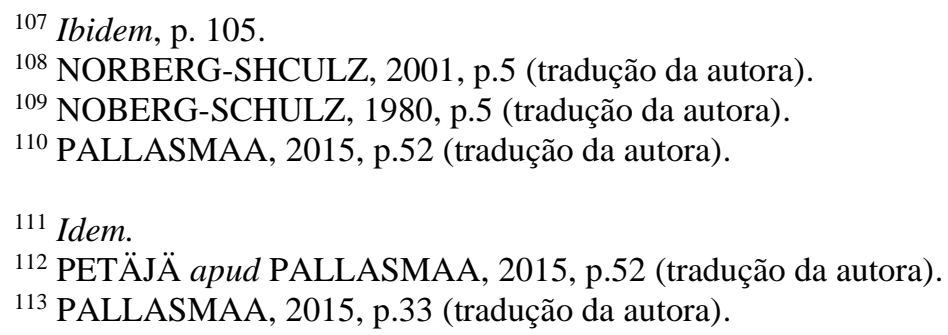


configurações arquitetônicas têm a capacidade de promover, enfraquecer ou destruir esses relacionamentos. ${ }^{114}$

Entender essa capacidade da arquitetura em moldar quem somos destaca a contribuição da profissão ao bem-estar humano. "Não julgamos os ambientes apenas pelos nossos sentidos, também os testamos e avaliamos através da nossa imaginação. Configurações reconfortantes e convidativas inspiram nossas imagens inconscientes, devaneios e fantasias" ${ }^{115}$. O modo como o espaço arquitetônico se configura impacta diretamente o bem-estar físico e mental de seus habitantes. Essas características podem ser reconhecidas como essências arquitetônicas, que se realizam somente por meio do ato de habitar. A essência do habitar está atrelada ao estabelecimento de uma relação de afeto com o ambiente que nos abriga.

114 PALLASMAA; ROBINSON, 2015, p.6 (tradução da autora).

115 PALLASMAA, 2015, p.80 (tradução da autora). 


\section{3}

\section{Hospitalidade}

"Um ato de hospitalidade só pode ser poético."

Derrida

\section{1.}

\section{O conceito de hospitalidade}

O diálogo entre a arquitetura e a filosofia se mostra frutífero. O pensamento filosófico de Derrida suscitou reflexões com desdobramento no campo projetual da arquitetura. Explora-se aqui o conceito da hospitalidade, tendo em vista seu posterior desdobramento no campo arquitetônico. Pode parecer paradoxal trazer à luz um conceito associado ao desconstrutivismo filosófico em uma leitura fenomenológica do espaço e das relações criadas a partir dela. No entanto, é válido pontuar aqui a diferença entre desconstrução da arquitetura e desconstrutivismo arquitetônico (associado a um aspecto formal). A desconstrução da arquitetura aponta para um desenho do espaço a partir do acolhimento, associado à ética da alteridade.

A raiz da palavra hospitalidade encontra-se associada à antiga hospitália romana, que era o lugar onde se tratavam os seres, o lugar onde se trata o outro, ou seja, morada dos acolhimentos ${ }^{116}$. Um contraponto interessante é que hotis, em latim, significa hóspede, mas também hostil, inimigo ${ }^{117}$. Hóspede é o termo utilizado para se referir a esse outro nas relações de hospitalidade por meio do binômio anfitrião e hóspede.

\footnotetext{
${ }^{116}$ FUÃO, 2015, p. 56.

${ }^{117}$ DERRIDA; DUFOURMANTELLE, 2003, p.6.
} 
O tema da hospitalidade tem ganhado visibilidade e, mais importante ainda, relevância desde o ponto de vista humanitário e dos direitos sociais como consequência dos fenômenos migratórios globais. O deslocamento de pessoas de uma origem demanda, do outro lado, no lugar de chegada, uma atitude de acolhimento. "O mundo tornou-se um espaço de circulação fácil de pessoas e bens; as fronteiras geográficas perderam [...] a rigidez física e legal que dificultava, ou mesmo impedia, a passagem de um país a outro" ${ }^{118}$. É nesse sentido que a hospitalidade emerge, no intuito de dar as boas-vindas ao estrangeiro que chega, de modo a acolhê-lo. Este dar as boas-vindas e acolhimento do estrangeiro possui dimensões políticas, éticas e poéticas que fazem dela algo complexo. Essa complexidade é fundamental no pensamento da arquitetura e das cidades nas suas diferentes escalas para a construção da fronteira onde o encontro entre os sujeitos e objetos envolvidos nesse encontro acontece.

A fronteira surge então como importante elemento para as relações aqui exploradas. Ao constituir esse lugar de mediação e transição, a fronteira desempenha importante papel na dinâmica do acolhimento daquele que chega. Por este motivo este elemento é transposto para o campo da arquitetura, por constituir o primeiro lugar de contato com aquele que é recebido.

Hoje em dia, uma reflexão sobre a hospitalidade pressupõe, entre outras coisas, a possibilidade de uma delimitação rigorosa das soleiras ou fronteiras: entre o familiar e o não-familiar, entre o estrangeiro e o não estrangeiro, entre o cidadão e o nãocidadão. Mas primeiramente entre privado e o direito público, etc. ${ }^{119}$

A hospitalidade, tal como concebeu Derrida, pressupõe duas figuras centrais: o hóspede e o hospedeiro ou o convidado e o anfitrião ${ }^{120}$. O hóspede carrega questões centrais para o gesto de acolhimento. "O hóspede é maior do que a casa onde chega, onde chegará" ${ }^{121}$, pois a pre-ocupa na expectativa da sua chegada. Sem ter chegado efetivamente, o hóspede já ocupa o seu lugar no desejo. Dufourmantelle destaca que, em alguns países, o estrangeiro acolhido é deus por um dia, reafirmando o papel de destaque daquele que é recebido em uma relação hospitaleira.

\footnotetext{
${ }^{118}$ HIGINO, 2010, p.9.

${ }^{119}$ DERRIDA; DUFOURMANTELLE, 2003, p.43.

${ }^{120}$ FUÃO, 2015, p. 50.

${ }^{121}$ HIGINO, Op.Cit, p.18.
} 
"Dar lugar ao lugar"122 parece ser a promessa mantida pela hospitalidade. "Também nos faz entender a questão do lugar como sendo fundamental, fundadora

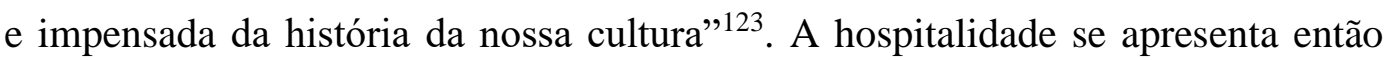
como esse gesto de ceder o lugar, de dar lugar ao outro que chega. É como se o "lugar que estava em questão na hospitalidade fosse um lugar que não pertencesse originalmente nem àquele que hospeda, nem ao convidado, mas ao gesto pelo qual um oferece acolhida ao outro"124. A hospitalidade é, portanto, uma característica essencialmente humana.

A hospitalidade pressupõe um gesto genuíno de acolhimento diante do outro. "Porque para ser o que ela deve ser, a hospitalidade não pode pagar uma dívida, nem ser exigida por dever: grátis, ela não 'deve' abrir-se ao hóspede nem 'conforme o dever""125. É nesse sentido que a hospitalidade absoluta parece romper com a hospitalidade de direito. Esta chamada hospitalidade absoluta exige, de acordo com Derrida, que se abra a casa e não apenas ofereça ao estrangeiro, mas efetivamente ao outro absoluto, desconhecido, anônimo, que lhe ceda o lugar, que o deixe vir, que o deixe chegar e ter um lugar no lugar que se oferece a ele sem exigir dele nem reciprocidade. Cruzar a soleira adquiri aqui importante significado para a realização de um acolhimento.

O senhor do lugar, não tendo preocupação mais urgente que aquela de derramar sua alegria sobre não importa quem que, à noite, vier jantar à mesa e sob seu teto repousar das fadigas do caminho, espera com ansiedade sobre a soleira de sua casa o estrangeiro que ele verá despontar no horizonte como um libertador. ${ }^{126}$

\footnotetext{
${ }^{122}$ DUFOURMANTELLE, Op. Cit., p.16

${ }^{123}$ Idem

${ }^{124}$ Ibidem, p.60

${ }^{125}$ DERRIDA; DUFOURMANTELLE, 2003, p.73

${ }^{126}$ Ibidem, p. 113
} 


\section{2.}

\section{Em busca de uma arquitetura da hospitalidade}

Procura-se aqui transpor o conceito de hospitalidade, geralmente associado ao terreno político e ético, ao campo estético, da arquitetura. Fuão destrincha o conceito na sua aplicabilidade no campo projetual:

A hospitalidade, desde Jacques Derrida, apresenta-se como um potente elemento para compreendermos a cidade e a arquitetura, não só para percebermos os lugares hospitaleiros e inóspitos, mas sobretudo para nos abrirmos para outro entendimento da arquitetura, em que as formas do acolhimento se traduzem em termos de abertura/fechamento, separação/união, recortar/colar, público/privado, familiaridade/não familiaridade. Enfim, o acolhimento se coloca como um desvelamento, um (de)voile, que nos permite ver a hospitalidade na arquitetura, na cidade, numa porta, num banco de praça, ou até mesmo nos materiais que empregamos numa obra. Há um sentido de acolhimento em todas as coisas no mundo. ${ }^{127}$

A hospitalidade deve ser pensada, portanto, desde a maçaneta da porta até a calçada da rua das cidades que habitamos, desde a luz que incide sobre a superfície até a própria questão do habitar o mundo. "A tal desconstrução na arquitetura não pode se restringir ao olhar do arquiteto, mas é fruto também das experiencias de outras pessoas. Estas leem, olham e se movem no espaço de modos distintos" ${ }^{28}$. Conceber o espaço a partir de uma abordagem humana, desde a experiência daquele que habita o lugar, é indispensável para uma arquitetura de hospitalidade. No extremo oposto estaria, então, uma abordagem por meio da qual a imagem se sobrepõe à experiência humana.

Arquiteturas que fecham seus discursos sobre si mesmas só podem gerar desumanidade, distanciamento, distanciam-nos da natureza e de seus elementares, obstaculizam nossa visão do mundo que nos cerca, ocultam o outro, subtraem o sentido de topicidade do lugar, da realidade do lugar e da natureza, oferecem hostilidade ao invés de hospitalidade. ${ }^{129}$

O verdadeiro objeto da arquitetura é o "humano que se esconde na arquitetura" ${ }^{130}$. Fuão considera, no entanto, que não há uma lógica que possa definir a hospitalidade e o sentir humano é que compreende que determinados lugares são mais acolhedores.

127 FUÃO, 2015, p. 43.

${ }^{128}$ SOLIS, 2005, p. 56.

${ }^{129}$ FUÃO, Op. Cit., p.103.

${ }^{130}$ Ibidem, p.66. 
$\mathrm{O}$ afeto se mostra, deste modo, pertinente à reflexão aqui colocada. "O acolhimento, assim como a hospitalidade, não são somente gestos, mas um movimento comparável à amância. A hospitalidade é a própria política da amizade e do amor"131. Revela-se oportuno, nesse sentido, explorar mais a fundo o âmbito emocional das relações espaciais.

O neurocientista Antonio Damasio, ao explorar o entrelaçamento entre neurobiologia e cultura, sugere que aspectos da emoção e do sentimento sejam indispensáveis para a racionalidade. $\mathrm{O}$ autor aponta também que corpo e cérebro interagem intensamente entre si e que esse organismo formado a partir dessa interação interage, por sua vez, com o ambiente que o rodeia. "O ambiente deixa

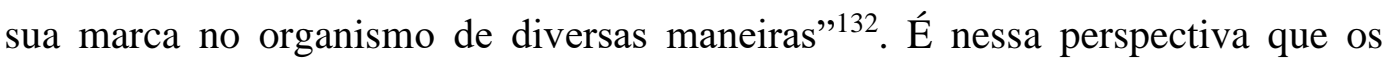
sentimentos adquirem importância central. "Os sentimentos parecem depender de um delicado sistema com múltiplos componentes que é indissociável da regulação biológica; e a razão parece [...] depender de sistemas cerebrais específicos, alguns

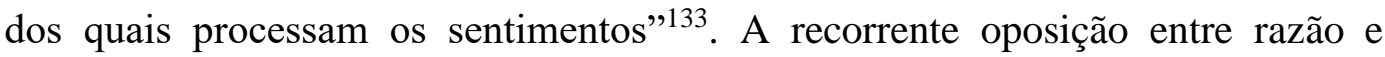
emoção parece, portanto, não fazer sentido. A emoção seria, na verdade, parte integrante do processo de raciocínio. E sendo assim, como seres humanos somos necessariamente seres emocionais.

Cabe então questionar aqui o papel da arquitetura como ambiente que estrutura a vida desse ser humano emocional. A arquitetura como materialização do habitar humano é território para reflexões acerca do campo psíquico. "Como arquitetos, nós não projetamos edifícios primordialmente como objetos físicos, mas como as imagens e os sentimentos das pessoas que os habitam"134.

Trazer o conceito de afeto à reflexão nos aproxima ainda mais da compreensão dos aspectos que operam na realização da hospitalidade na arquitetura. Isto porque ao nos sentirmos acolhidos, estabelecemos uma relação de afeto com aquele contexto. "Quando reconhecida como lugar afetivo, a cidade se torna um centro de significados, um ponto de referência, um refúgio, um abrigo" ${ }^{135}$.

Segundo Damasio, em seus estudos acerca da obra de Baruch Espinosa, na relação entre sujeito e objeto, o afeto é uma reação física interna (sentimento) e

\footnotetext{
131 Ibidem, p.49.

${ }^{132}$ DAMÁSIO, 2012, p.97.

133 Ibidem, p. 216.

${ }^{134}$ PALLASMAA, 1986. In: NESBITT, 2008, p.485.

${ }^{135}$ CASTELLO, 2017, p.8.
} 
externa (emoção) ${ }^{136}$. O próprio ato de projetar, como apontado por Espósito, depende dessa capacidade de estabelecer uma relação com o contexto de intervenção, considerando seu âmbito físico e social, na qual a percepção possui uma variável interna e outra externa ${ }^{137}$. Estes âmbitos são influenciados um pelo outro, de modo que o projeto começa com a capacidade de impressão (consequência da experiência com o contexto específico), seguida pela expressão (também consequência daquela experiência contextual). Os projetos decorrentes dessa relação estabelecida previamente entre arquiteto e contexto, aponta Espósito, afetarão o contexto de intervenção, o que será determinante para a reação do habitante diante desse contexto modificado. O projeto arquitetônico trata, portanto, de uma reação sensível em relação ao outro. "O arquiteto é, ao mesmo tempo, arquiteto e habitante de um mundo que contempla, que observa, mas também se antecipa 'esteticamente' a partir dessa reinterpretação 'ética' de internalizar o contexto a partir de se colocar no lugar do outro" ${ }^{138}$.

O gesto de colocar-se no lugar do outro traz para a reflexão, também, a noção de empatia. Duarte fomentou no Laboratório de Pesquisa "Arquitetura, Subjetividade e Cultura" (LASC/UFRJ) o desenvolvimento do conceito de empatia espacial, a fim de "elencar as características espaciais que permitem que o usuário se sinta acolhido pelo lugar". A noção de empatia espacial é consoante a ideia de lugar da hospitalidade. Empatia diz respeito a capacidade de colocar-se no lugar do outro, buscando compreender seu ponto de vista. Essa alteridade é também aspecto fundamental para a construção de uma hospitalidade na arquitetura. O gesto de acolhimento depende de uma compreensão sensível da vivência do outro. "Entendemos que projetar espaços que proporcionem maior empatia espacial nas cidades depende da compreensão do papel das ambiências na geração de afetos pelo Lugar"139. Estabelecer a conexão afetiva com o lugar depende, portanto, de projetos que levem em conta a experiência espacial do habitante, em um gesto de empatia com ele, acolhendo-o de modo hospitaleiro. A construção de um espaço empático está em profunda sintonia com a construção do lugar da hospitalidade.

\footnotetext{
${ }^{136}$ DAMASIO apud ESPÓSITO, 2011, p.86 (tradução da autora).

${ }^{137}$ ESPÓSITO, 2011, p.87 (tradução da autora).

${ }^{138}$ Ibidem, p.199

${ }^{139}$ DUARTE, 2016, p.72.
} 
De acordo com Fuão, a hospitalidade nunca é um terreno vazio ou um loteamento do espaço, mas uma relação entre pessoas, os ambientes, o lugar que edifica o lugar. "A tarefa da hospitalidade é preparar um lugar, construir um lugar, oferecer um lugar ao que chega, ao que está sempre a chegar em cada momento" ${ }^{\text {140. }}$. Cabe pontuar aqui a questão do habitar. Qual seria a diferença entre as figuras do habitante e o hóspede?

O habitável está tradicionalmente ligado à ideia de acolhimento, abrigo e conforto. [...] Habitar, portanto, está associado à ideia de bem-estar, de receptáculo confortável e o exterior como sendo o lugar senão do inóspito, ao menos daquilo de certa forma desconhecido, o estranho. [...] O estável, o contido é o familiar, o domiciliar, o estar dentro faz a ideia de intimidade, particular e em grande parte subjetiva. $\mathrm{O}$ fora é a instabilidade, $\mathrm{o}$ aberto. ${ }^{141}$

O habitante poderia ser definido, portanto, como o indivíduo acolhido pelo espaço, em abrigo, que habita o lugar em sua essência. O hóspede, por sua vez, diz respeito ao desconhecido que chega à fronteira e é recebido. Sob esta lógica, a hospitalidade possui o intuito de transformar o hóspede em habitante. Ao cruzar a fronteira da hospitalidade o convidado é acolhido e pode finalmente habitar o lugar.

A espera está diretamente relacionada ao âmbito da hospitalidade. "O acolhimento é como uma espera, parte da espera, é o espaço de espera que acolhe. [...] Essa é a essência da cidade: esperar a chegada dos outros"142. Portanto, acolher o outro passa por preparar o lugar. Significa preparar previamente o lugar de acolhimento, suas aberturas, de modo a dar passagem ao que chega. Emerge aqui a questão do tratamento do lugar, as estratégias e elementos atribuídos ao espaço para a consecução de um lugar da hospitalidade. Mais que isso, evidencia-se aqui o tratamento das fronteiras, que se diluem para acolher o habitante. Encontra-se aqui um desafio para uma arquitetura da hospitalidade. A relação entre quem recebe $\mathrm{e}$ quem chega é marcada por barreiras não apenas físicas. Existem barreiras invisíveis que trazem a sensação de ameaça para esta relação. A construção de um espaço orientada pela hospitalidade permite explorar a potencialidade da interação social. "Na experiência, encontramos o outro. Esses encontros são transformadores sim, nos modificam." $" 143$

\footnotetext{
${ }^{140}$ HIGINO, Op. Cit., p. 28.

${ }^{141}$ SOLIS apud FUÃO, 2015, p. 63.

${ }^{142}$ FUÃO, Op. Cit., p.68.

${ }^{143}$ HAN, 2017, p.84.
} 
“A hospitalidade é uma questão muito mais de abertura, vazão, espera, do que de território ou cercamento"144. Hospitalidade pressupõe a abertura, pois um lugar fechado jamais será hospitaleiro para aquele que está além da fronteira. Essa abertura significa uma abertura para a possibilidade. Fuão associa a errância à arquitetura, os espaços que possuem a capacidade de fazer a passagem, conectando diferenças, não somente geográficas, mas sobretudo sociais, como as pontes, as escadas, as portas, dentre outros, ou simplesmente elementos que de algum modo se transformam em conectores. "Todo discurso sobre o lugar (topologia) implica uma incisão, a inscrição de um traço que, marcando fronteiras, está destinado a violá-las" ${ }^{145}$. A abertura do ambiente construído fica evidente no projeto da Praça das Artes, em São Paulo, por exemplo. O projeto foi concebido pelo escritório Brasil Arquitetura e inaugurado em 2012. O projeto da Praça das Artes reabilitou a edificação do Antigo Conservatório Dramático Musical, vinculando-o a um complexo de novas construções. O corte do edifício (Figura 3) demonstra a continuidade atribuída ao espaço, em relação ao contexto urbano.

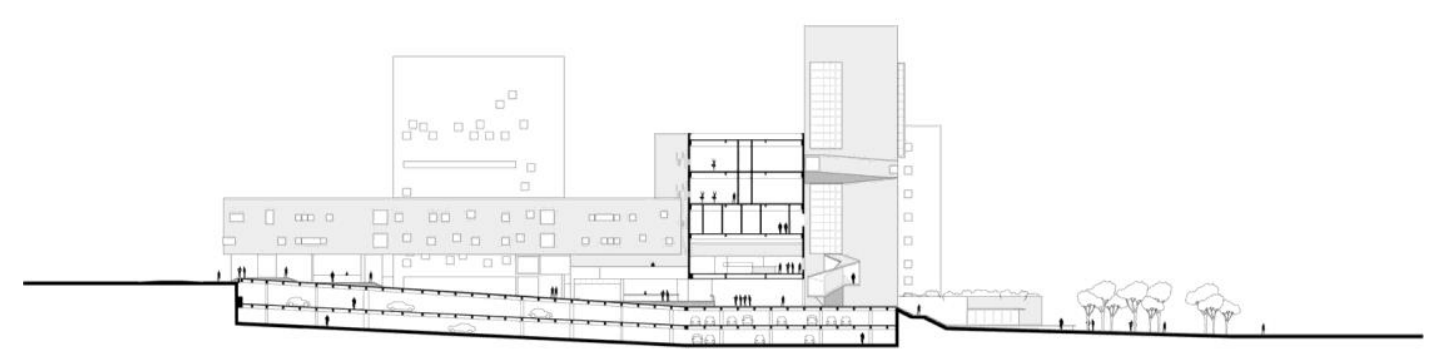

Figura 3: Corte Praça das Artes

Fonte: https://www.archdaily.com.br/br/626025/praca-das-artes-brasil-arquitetura

\footnotetext{
144 Ibidem, p.52.

${ }^{145}$ HIGINO, Op. Cit., p.31.
} 
Desta forma, em uma aproximação aos elementos da arquitetura que realizam as incisões nessas fronteiras, é possível reinterpretá-las desde essa perspectiva e atribuir-lhes o caráter hospitaleiro. Se pensarmos nesses elementos que constroem de algum modo esse lugar da hospitalidade, a porta é o primeiro que surge desta reflexão.

A porta constitui-se um lugar limite, uma borda, um umbral, uma sombra, uma fronteira; tanto aberta como fechada, ela é sempre o anúncio de uma fissura, uma fratura na continuidade do espaço, como uma dobra. Situar-se na frente dela é colocar-se no limite do espaço da espera, da chegada. ${ }^{146}$

"A hospitalidade é abertura, vazão, interioridade, porta aberta, entreaberta" "147. Não é possível um acolhimento sem a abertura. Cabe aqui, no entanto, a distinção entre porta e janela, feita por Vilém Flusser e apresentada por Fuão em As formas do acolhimento na arquitetura. Segundo Flusser, a porta é um elemento de comunicação e participação direta entre público e o privado. Pela janela, por outro lado, observamos a vida pública sem sermos impactos por intempéries. A janela torna-nos, portanto, observadores e não atores.

Outros elementos podem ser vistos desde a perspectiva da hospitalidade. Um deles, também citado por Fuão, seria o banco. "O banco é uma casa sem telhado ou portas, ele se torna um lugar, um ambiente, faz do espaço um lugar, nele o mundo se torna recinto" ${ }^{148}$. Essa colocação nos faz pensar nas praças e ruas como lugares do acolhimento. "A rua vira praça, a rua vira casa"149. Essa relação fica evidente no caso da praça São Salvador, bairro de Laranjeiras, no Rio de Janeiro (Figura 4). O espaço formado por bancos com duas alturas diferentes, possibilita diferentes usos e relações entre habitante e lugar. A altura maior configura espécie de mureta, que serve também de encosto para o banco mais baixo. Além disso, a disposição desse elemento na praça conforma também um limite para o espaço interno, onde se podem realizar variadas atividades. Este elemento configura, desta forma, uma fronteira, permeável, que permite a habitabilidade em si mesma. Esse lugar é conhecido localmente por diversas atividades culturais (Figura 5), que estimulam o encontro entre habitantes. O espaço da Praça São Salvador será explorado de modo mais profundo no capítulo 5 .

\footnotetext{
${ }^{146}$ FUÃO, F. Op. Cit., p.111.

${ }^{147}$ Ibidem, p.70.

148 BECKER apud FUÃO 2015, p. 77.

${ }^{149}$ FUÃO, Op. Cit., p.104.
} 


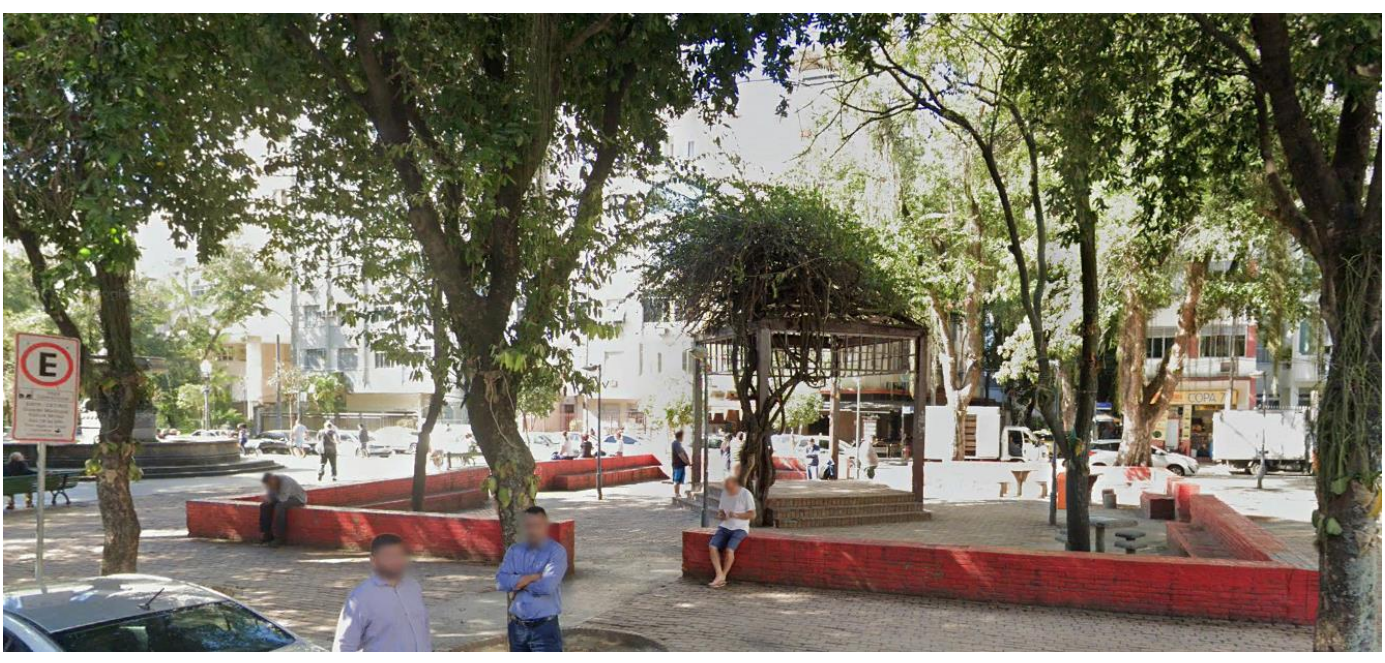

Figura 4: Praça São Salvador

Fonte: Street View Google Earth

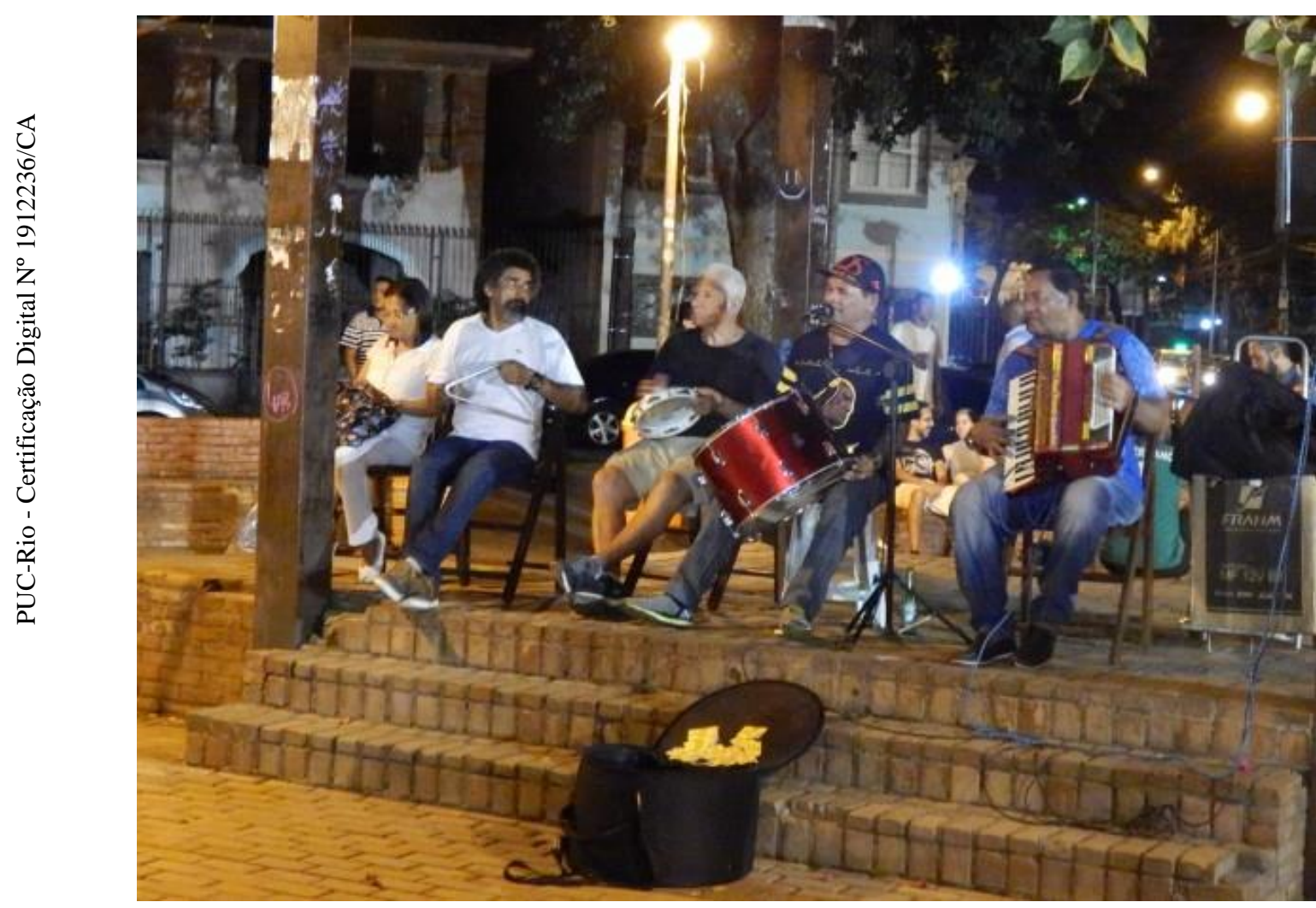

Figura 5: Forró na Praça São Salvador

Fonte: http://revistaplaneo.cl/2016/12/12/la-plaza-sao-salvador-rio-de-janeiro-brasil-lamusica-como-catalizador-de-apropiaciones-en-el-espacio-urbano/ 
Esta observação do espaço vivido reitera a questão das escalas da hospitalidade. $\mathrm{O}$ acolhimento se dá por meio de diversos elementos e gestos. O banco, ou mureta, é um deles. Este elemento é capaz de integrar pessoas ao espaço da praça, pois, um simples elemento pode ser reinterpretado de diferentes maneiras de acordo com os usos e circunstâncias dos encontros e permanências naquele lugar. Isso traz para questão a flexibilidade como possível aspecto da hospitalidade. A fronteira como espaço de apropriação flexível, que tolera diferentes possibilidades de ocupação, configura uma fronteira da hospitalidade. A adaptabilidade às diferentes formas de habitar o espaço é um aspecto importante.

Outro exemplo onde identificamos o elemento da mureta como gerador de hospitalidade na cidade é a Mureta da Urca (Figura 6), localizada no bairro da Urca, no Rio de Janeiro. A mureta, que se localiza no limite entre as avenidas João Luís Alves e Portugal e o mar, configura um lugar de encontro e permanência, amplamente utilizado na cidade. Mais uma vez, este elemento atua como um catalisador de encontros sociais, por garantir o acolhimento do habitante nessa fronteira. A mureta da Urca também será analisada como estudo de caso no capítulo 5.

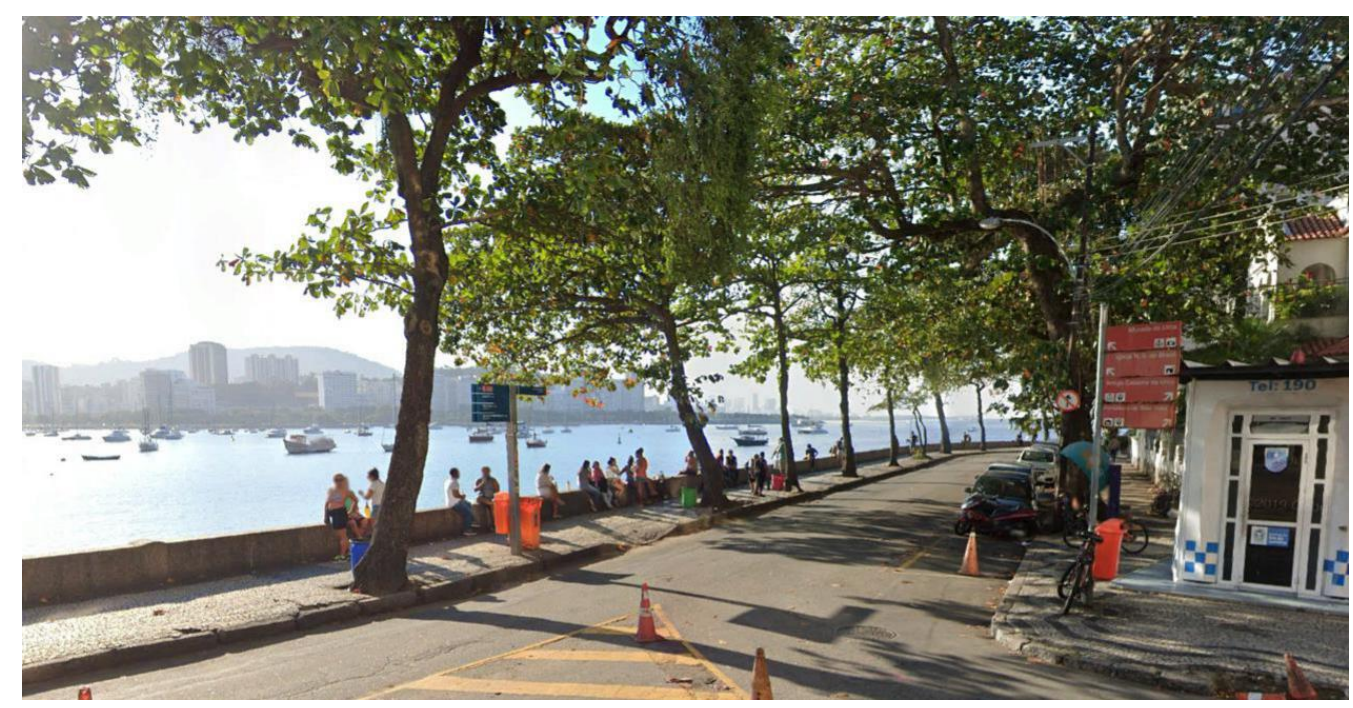

Figura 6: Mureta da Urca

Fonte: Street View Google Earth 
Ainda dentro desta identificação de elementos que atuam na elaboração de um espaço hospitaleiro, explora-se o exemplo da Ribeira das Naus (Figura 7), em Lisboa, que conecta a Praça do Comércio à estação intermodal do Cais do Sodré, e passou por processo de requalificação dos espaços públicos, inaugurado em 2014, sob autoria dos arquitetos João Nunes, João Gomes e Carlos Riba. O projeto propicia diversos usos do espaço à beira do Rio Tejo, como circulação, contemplação e permanência.

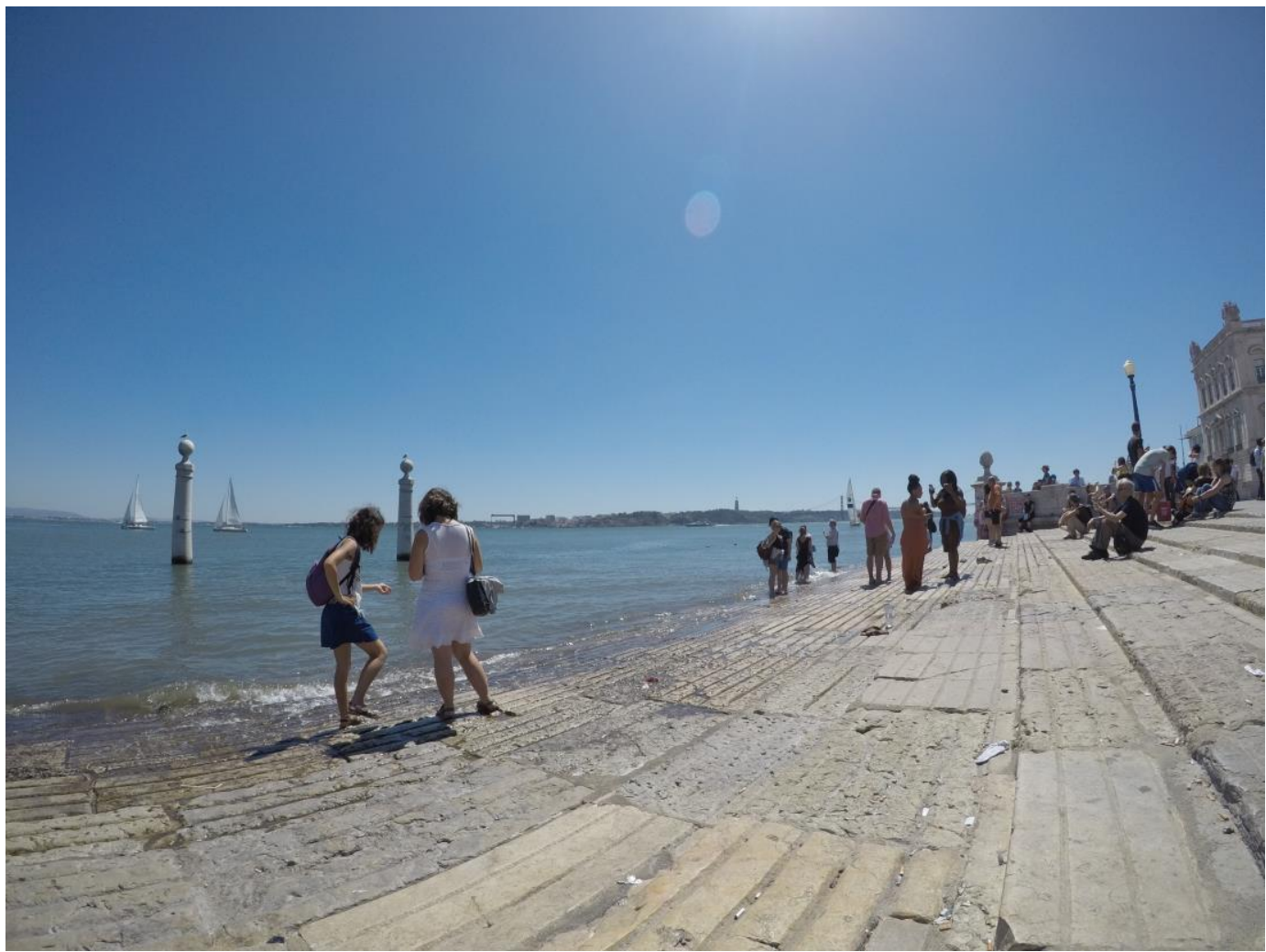

Figura 7: Ribeira das Naus

Fonte: Elaborado pela autora

Neste caso, o chão pode ser identificado como elemento gerador de hospitalidade. Do nível da via, até o nível da água, esse lugar é conformado por suaves declives que configuram um espaço de estar. Em outros trechos, o projeto de requalificação trouxe mobiliário (Figura 8) para a zona ribeirinha, em uma vasta área próxima às muretas, possibilitando a extensão da ocupação e permanência dessa zona. 


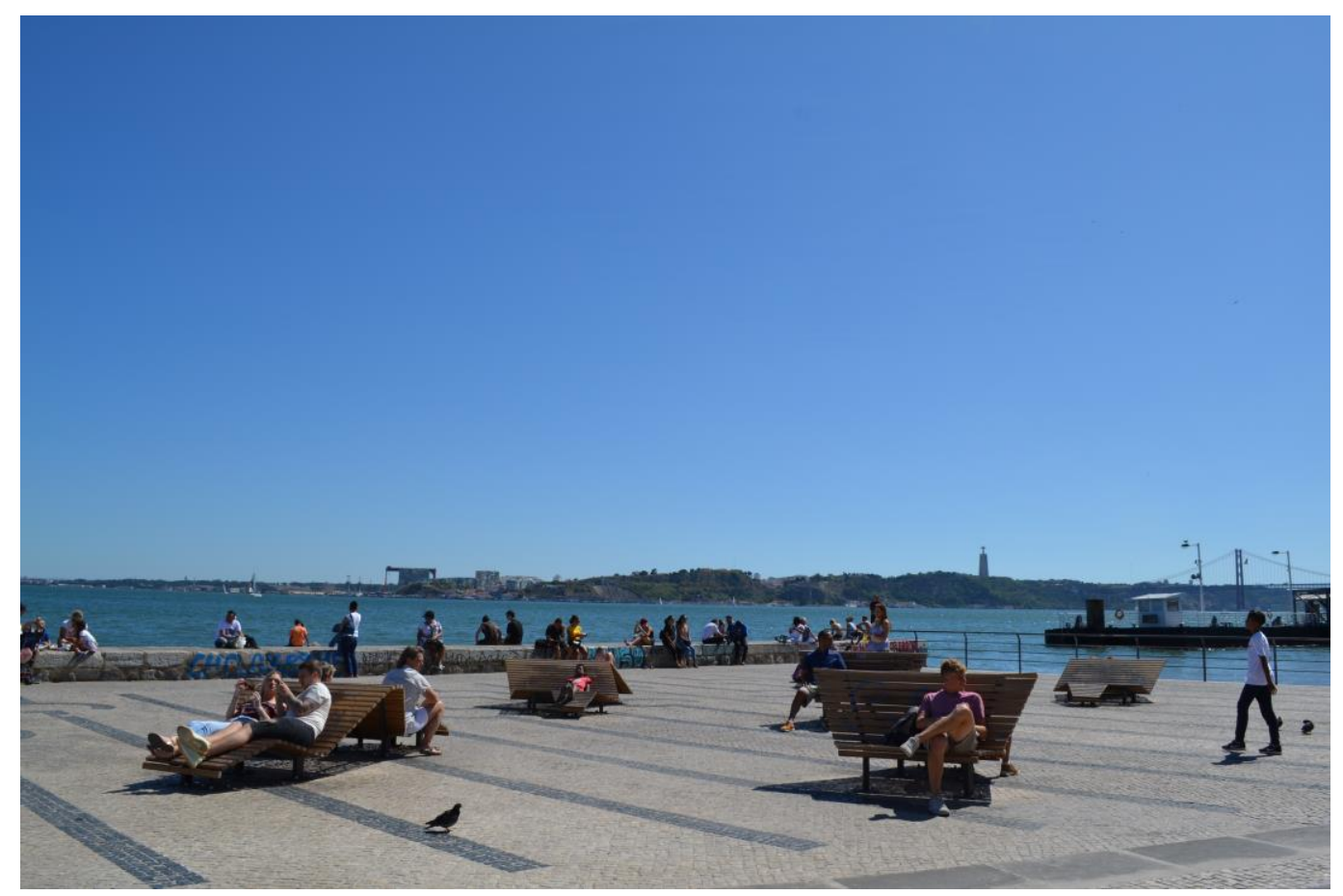

Figura 8: Mobiliário Ribeira das Naus

Fonte: Elaborado pela autora

A partir do exemplo da Ribeira das Naus portuguesa, levanta-se aqui um outro aspecto fundamental à compreensão da hospitalidade da arquitetura: o aspecto cultural. Tuan, ao levantar a questão de como as pessoas atribuem significado e organizam o espaço, coloca a cultura como um fator explicativo desse processo. Isto porque que ela influencia profundamente o comportamento humano e, por consequência, sua relação com o espaço. Isto significa que possivelmente os gestos hospitaleiros atribuídos ao espaço em Portugal não garantiriam por si só a construção da hospitalidade em um contexto brasileiro. Existem dimensões sociais, e também geográficas, fundamentais para a realização de um lugar da hospitalidade. As vivências humanas estão diretamente relacionadas aos seus respectivos contextos. A identificação de espaços hospitaleiros nas cidades brasileiras, por exemplo, normalmente demanda a presença de áreas sombreadas, seja pela conformação do vão livre arquitetônico, seja pela presença de árvores.

Pessoas de diferentes culturas diferem na forma de dividir seu mundo, de atribuir valores às suas partes e de medi-las. As maneiras de dividir o espaço variam 
enormemente em complexidade e sofisticação, assim como as técnicas de avaliação de tamanho e distância. ${ }^{150}$

Outro exemplo que destaca a questão cultural como aspecto indissociável da hospitalidade é o projeto do Conjunto da Bouça (Figura 9), projetado por Álvaro Siza. O desenho de implantação em pente, se volta para uma via principal mais movimentada, garantindo a continuidade da calçada em relação aos pátios internos conformados (Figura 10). Isso pode ser relacionado à cultura portuguesa e sua relação com o espaço. O conjunto Habitacional Rincão (Figura 11), projetado por Hector Vigliecca, guarda algumas semelhanças em relação a este projeto: o tipo de implantação e o acesso individualizado as unidades por meio de escadas. $\mathrm{O}$ acesso à implantação em pente é marcado no caso do Rincão, no entanto, por uma barreira física, que podemos associar a uma característica relação dos espaços habitacionais com seus entornos no cenário brasileiro. Esse dado ressalta o fator cultural como um dos componentes de análise da hospitalidade. Do ponto de vista da escala do corpo, ambos expressam o caráter hospitaleiro do espaço, por meio das escadas e jardins de acesso. Sob o aspecto da escala urbana, no entanto, os projetos diferem em função de um aspecto que é intrínseco à cultura arquitetônica brasileira.

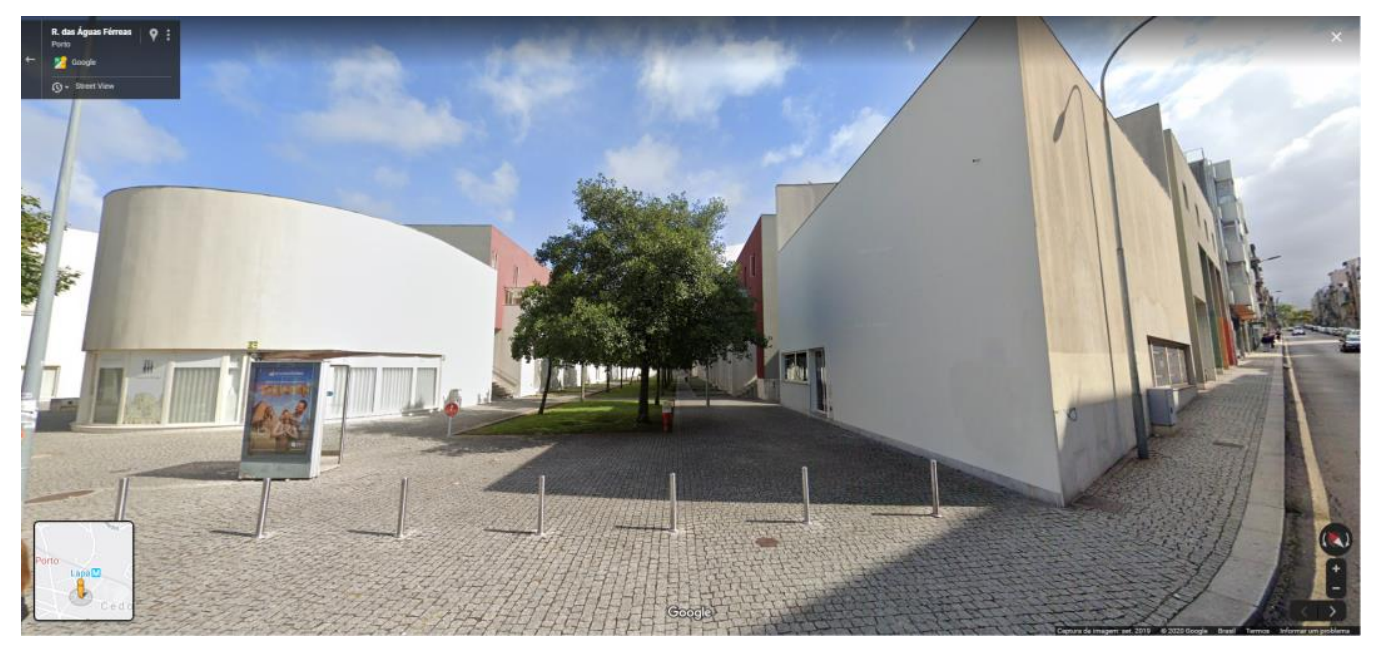

Figura 9: Conjunto Habitacional da Bouça

Fonte: Street View Google Earth

${ }^{150}$ TUAN, 2012, p.39. 


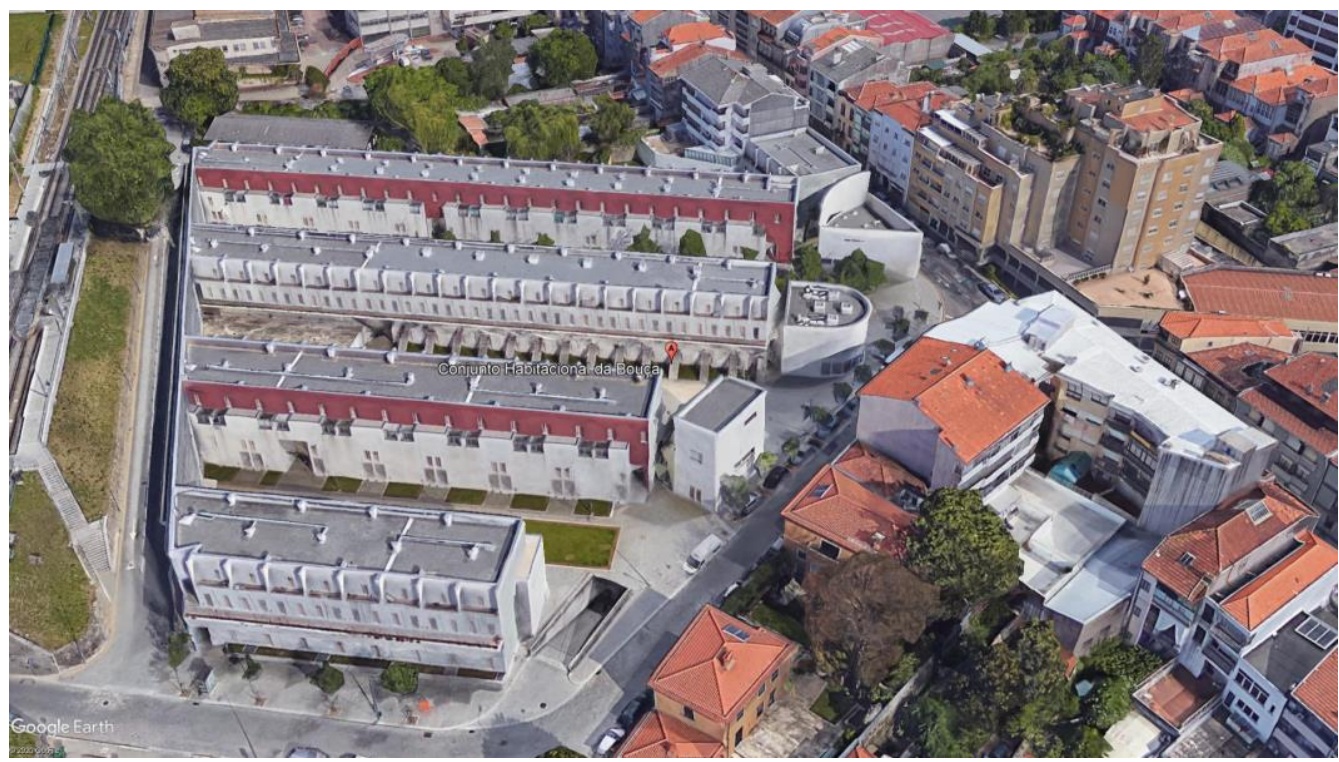

Figura 10: Implantação Conjunto Habitacional da Bouça

Fonte: Google Earth

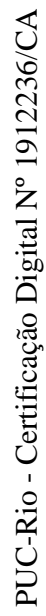

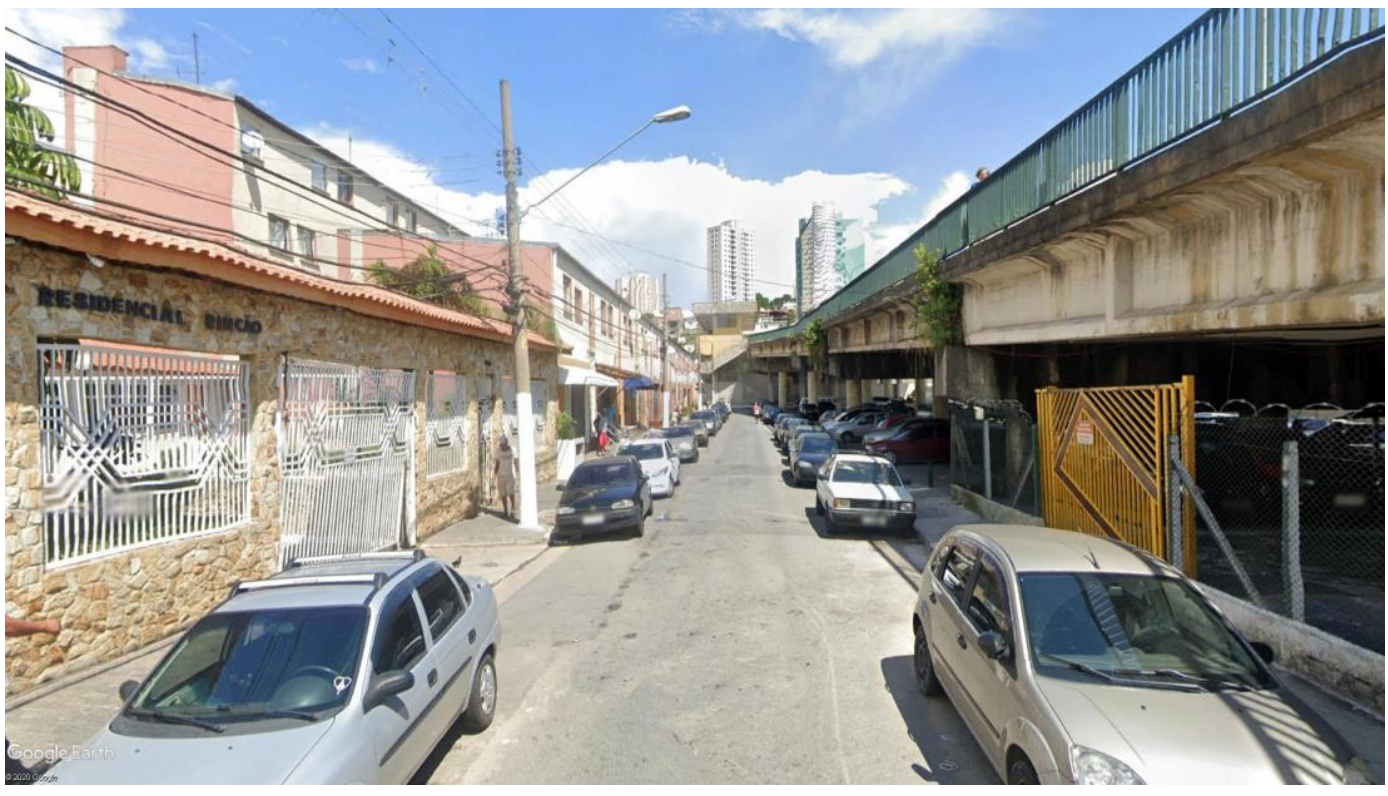

Figura 11: Conjunto Habitacional Rincão

Fonte: Street View Google Earth 


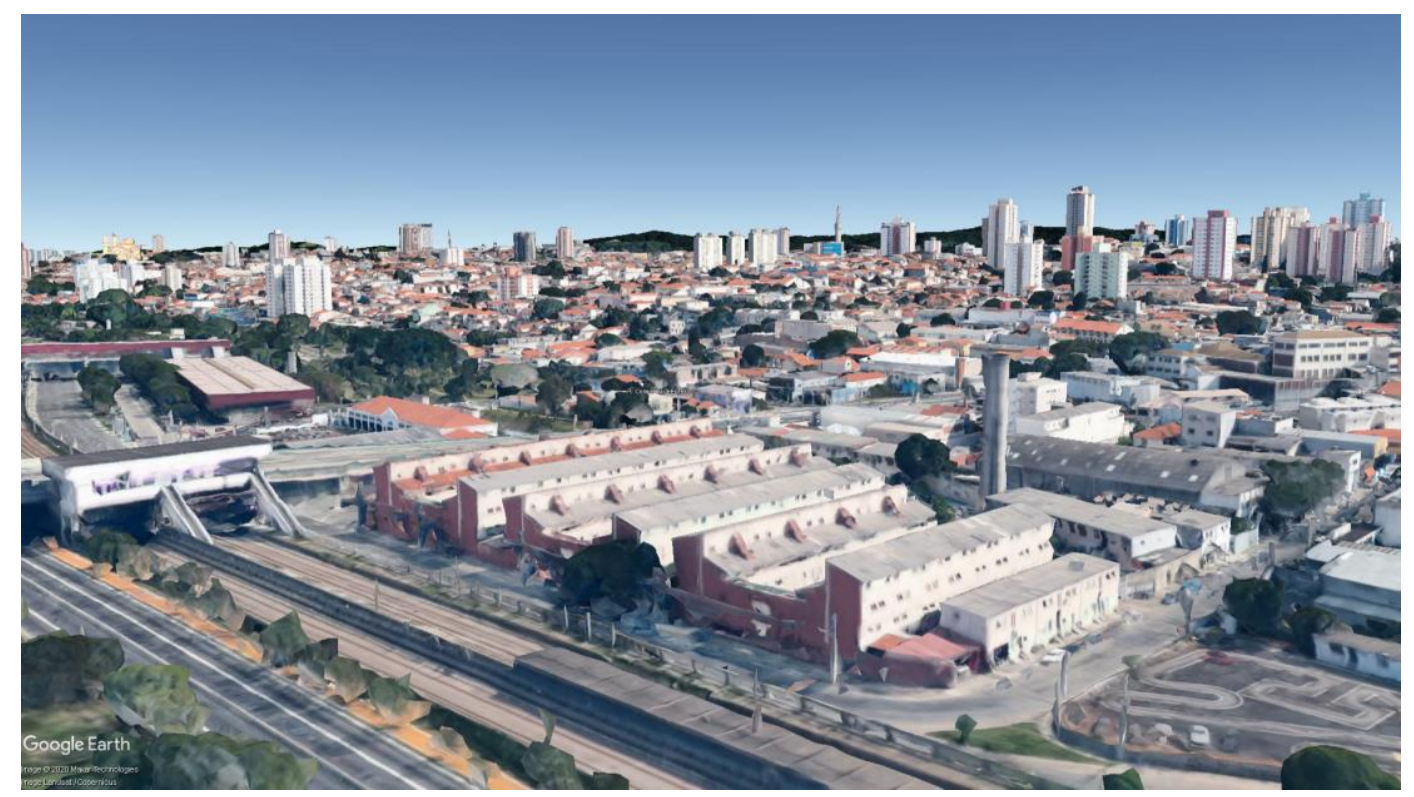

Figura 12: Implantação Conjunto Habitacional Rincão Fonte: Google Earth

Como já abordado, a experiência humana do espaço é intrínseca à hospitalidade da arquitetura. Escala do corpo e sua experiência sensorial são diretamente afetadas pela escolha dos materiais e composição formal. O SESC Pompeia (Figura 13), projetado por Lina Bo Bardi, é um exemplo disso. Fruto da requalificação de uma antiga fábrica, "o lugar funciona como uma rua aberta e convidativa, diferentes áreas de exposições, atividades de lazer e aprendizado, restaurante público além de uma extensa programação cultural"151. A via de serviços da antiga fábrica torna-se o eixo principal organizador do conjunto e o galpão é convertido em espaço multiuso. O lugar é "qualificado por incisões poéticas: um sinuoso espelho d'água apelidado de Rio São Francisco e uma grande lareira aberta" ${ }^{\prime 152}$. Essas chamadas incisões poéticas são definidoras da experiência

${ }^{152}$ PEDROSA; CUY; GONZÁLEZ; TOLEDO, 2019, p.292. 
humana desse lugar, estimulam laços afetivos e constroem, em certa escala, um lugar de hospitalidade.

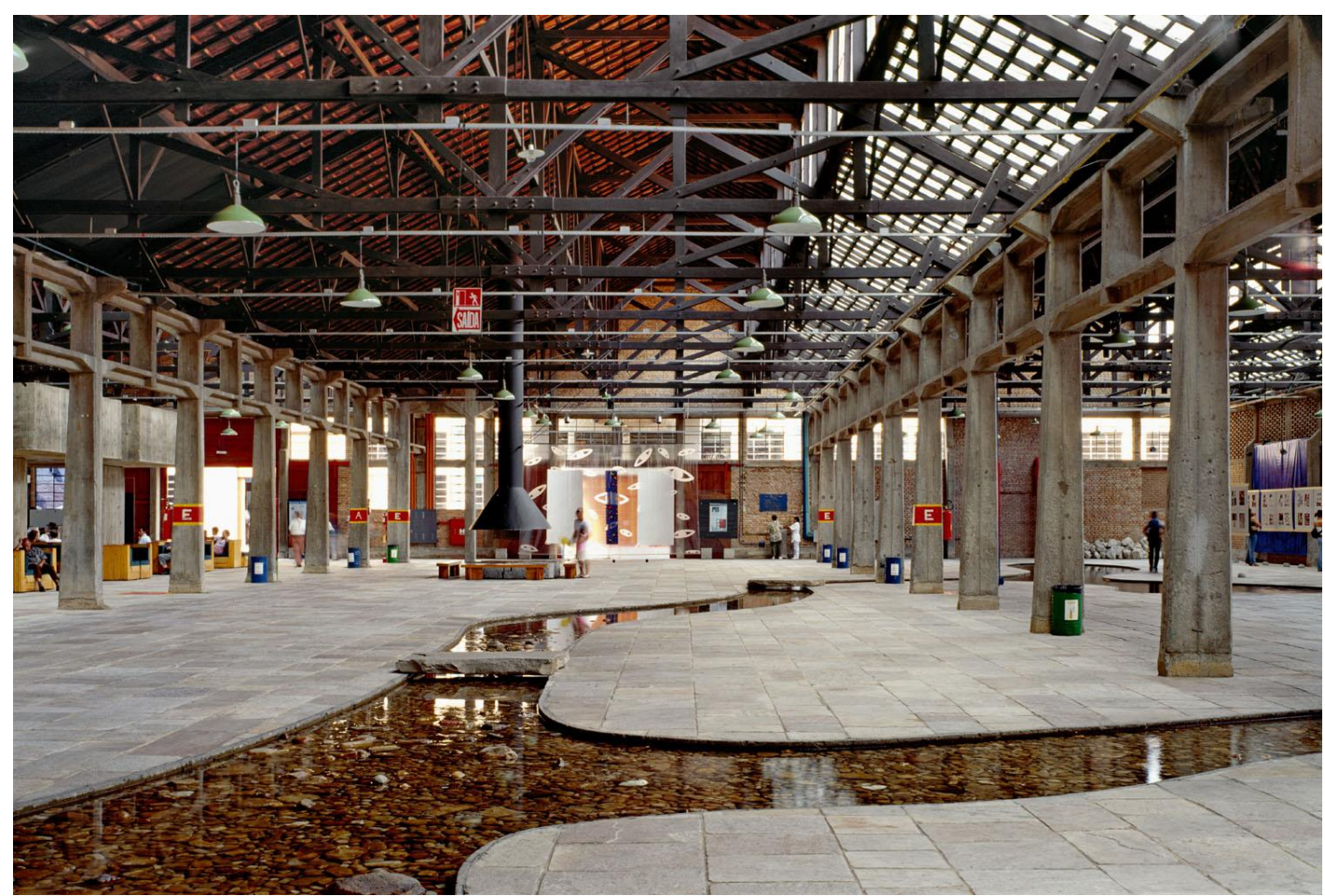

Figura 13: SESC Pompeia

Fonte: http://www.nelsonkon.com.br/sesc-pompeia/

Vale destacar que a recente revalorização da arquitetura fenomenológica e da experiência se encontra relacionada com a paulatina revalorização da teoria e obra de Lina Bo Bardi. ${ }^{153}$ A obra de Lina é uma "contundente expressão da arquitetura popular que utilizava materiais acessíveis e orçamentos modestos e que se relacionava intensamente com o lugar"154. A concepção de Lina acerca da arquitetura está associada ao coletivismo e a poesia. "Para ela a arquitetura deveria ser simples. Embora fosse bastante conceitual, Lina Bo Bardi buscava criar desenhos com impacto social, que se comunicassem imediatamente com o público, com o povo, dotando-os assim de um sentido de coletividade"155.

\footnotetext{
${ }^{153}$ MONTANER, 2016, p.57.

${ }^{154}$ Idem.

${ }^{155}$ PEDROSA; CUY; GONZÁLEZ; TOLEDO, 2019, p.35.
} 
Uma arquitetura da hospitalidade demanda um olhar atento à vivência humana do lugar. Acolher o indivíduo, de modo a assegurar que ele habite o espaço, é uma tarefa que permeia diferentes escalas de projeto. Um tratamento do ambiente que atua desde a textura dos materiais até a articulação com seu entorno. Assim se define uma arquitetura da hospitalidade. Aberta e receptiva à chegada do desconhecido. 


\section{3.}

\section{(Po)ética da hospitalidade}

É importante considerar a abrangência e complexidade do conceito de hospitalidade. Sua relevância aponta para a pertinência de sua discussão em uma ampla gama de temas, em variados campos. Pretende-se aqui, portanto, explorar a dualidade ética-estética deste conceito. É nesse sentido que se destaca que a própria percepção ética da hospitalidade ressalta sua significação poética. A palavra poética, por si só, vista de modo isolado da sua etimologia, é composta pelo termo ética. Isto foi ressaltado por Farias e Fuão em suas obras. Esta observação sugere que tratar a hospitalidade como poética parece ser suficiente para ressaltar seu aspecto ético. Explora-se a seguir estas duas dimensões, que convém serem tratadas de modo coextensivo, reconhecendo o vínculo entre ética e estética. "A compreensão do ético depende do que há de poético no território da hospitalidade" ${ }^{\prime 156}$.

\footnotetext{
${ }^{156}$ FARIAS, 2018, p.136.
} 


\subsection{1.}

\section{Poética da hospitalidade}

"A hospitalidade se expressa talvez mais imediatamente como uma ética, depois, mas ao mesmo tempo, como uma política, porém, antes de tudo ela é uma poética" ${ }^{157}$. Derrida afirma que a hospitalidade é um ato poético. É importante, nesse sentido, destacar aqui o significado de poética, e a partir disso, seu desdobramento em uma poética do espaço. Bachelard apresenta a imagem poética da seguinte forma:

Para esclarecer filosoficamente o problema da imagem poética, é preciso chegar a uma fenomenologia da imaginação. Esta seria um estudo do fenômeno da imagem poética quando a imagem emerge na consciência como um produto direto do coração, da alma, do ser do homem tomado em sua atualidade. ${ }^{158}$

A poética está associada à construção que comunica com o ser humano. A experiência poética expressa um vínculo entre o leitor e o escritor ou entre o habitante e arquiteto. "Entende-se por poética a dimensão criadora da dimensão humana [...]. No conceito em questão, a dimensão poética é o ato de criar as condições do acolhimento hospitaleiro independentemente das condições já existentes." ${ }^{159}$ Associa-se aqui a concepção arquitetônica à poética, a partir de sua dimensão criadora, de intervenção voltada para o acolher.

Para uma arquitetura da hospitalidade é necessário explorar a dimensão poética que representa a dimensão humana de uma obra. A relação do habitante com o ambiente construído parece estar diretamente relacionada a esta dimensão poética. "O ato poético é um gesto hospitaleiro. [...] Pois o que é o ato poético senão a porta aberta por onde penetra algo de novo e estranho, a realização de um lugar para o absolutamente outro?" 160

Trata-se da perspectiva estética da hospitalidade. "No domínio estético tratase não de apenas um estado emocional do sujeito, mas da relação com o outro, configurada pelo contato afetivo com o mundo."161 É nessa experiência estética,

\footnotetext{
${ }^{157}$ FARIAS, 2018, p.136.

158 BACHELARD, 1993, p.2.

${ }^{159}$ FARIAS, Op. Cit., p. 135.

${ }^{160}$ FARIAS, Op. Cit., p. 143.

161 VELLOSO, 2010, p.137.
} 
que o corpo, guiado pela percepção sensorial, possui papel central. "É o corpo quem dá a medida da relação do indivíduo com o mundo, a que se pode chamar 'estética'; é o corpo 'e suas funções que dão ao estético sua preeminência como operação guiada pelo sensório",162.

Uma arquitetura da hospitalidade, ao buscar estabelecer relação com o ser humano, seja ele quem for, constrói uma experiência poética do espaço. Essa poética é vista de modo indissociável de seu valor ético. Acolher o estrangeiro, o outro ou o estranho pode ser lido como uma postura (po)ética.

Se está viva, a cultura continua acontecendo, e ela continua durando justamente porque há o gesto hospitaleiro, que é poético porque é capaz de remover as resistências e ceder espaço para o estranho, o esquisito, o incongruente, mas também ceder para o admirável ${ }^{163}$.

Vale pontuar ainda a relação dessa dimensão poética com o conceito de habitar, explorado anteriormente. "O poetizar, antes de mais nada, põe o homem sobre a terra, leva-o a ela, leva-o a habitar." ${ }^{164}$ O habitar expressa a relação humana com o lugar, e é por isso poético. A hospitalidade arquitetônica, em sua essência, apresenta, portanto, a necessidade de abrigo humano, em um âmbito físico e em outro afetivo. "A hospitalidade exige um lugar de acolhimento, um espaço próprio de habitação para o qual se dirige o hóspede, aquele que chega vindo de fora, seja convidado ou não". ${ }^{165}$

162 CAUNE apud VELLOSO, 2010, p.137.

${ }^{163}$ FARIAS, 2018, p.144.

${ }^{164}$ HIGINO, 2010, p. 51.

${ }^{165}$ Idem, p. 47. 


\subsection{2.}

\section{Ética da hospitalidade}

A dimensão ética da hospitalidade fica evidente no gesto de acolhimento irrestrito em relação ao outro. No entanto, "o primeiro acolhimento é acolher a ideia do próprio acolhimento, incluir o outro, pensar a partir do outro, para que se possa restabelecer uma ética da arquitetura; abrir espaço, dar passagem à chegada do outro."166 Esse "dar passagem" desloca o projeto para o plano ético e é requisito para uma arquitetura da hospitalidade. "É no acolhimento do estranho que a hospitalidade revela sua natureza de discurso ético" 167 .

Desta forma, a essência da hospitalidade possui indubitavelmente uma natureza ética. É importante pontuar, no entanto, que "é no limite do identificável que começa a ética. Não há verdadeira hospitalidade se apenas o reconhecido tiver lugar, ou se não estiver aberta a possibilidade de desconhecer, ainda, o que já foi reconhecido [...]"168. Isso significa acolher de modo irrestrito, independente de quem chega à fronteira. "A competência ética fundamental consiste na abertura em relação ao outro e os outros, em estar acessível aos requisitos do mundo, atento ao diferente de si mesmo." $" 169$

“A organização que caracteriza a cidade formal é basicamente a segregação espacial"170. A dinâmica socioespacial de uma cidade é determinante para a realização ou não de uma arquitetura da hospitalidade. Em algumas áreas da cidade é possível identificar esse fenômeno de modo mais expressivo. "Quando a differenza se desloca, entra no outro território e começa a participar da vida do outro, aí então ocorre realmente uma mudança do espaço e da arquitetura.” É na recepção e convívio que reside as relações entre hóspede e anfitrião. "O fato de sermos hóspedes uns dos outros [...] significa que nossa instalação no mundo têm a estrutura da recepção e o encontro" ${ }^{171}$. É por esse motivo que a abertura é condição para a hospitalidade. É o primeiro gesto de acolhimento daquele que chegar à

\footnotetext{
${ }^{166}$ FUÃO, 2015, p. 43.

${ }^{167}$ FARIAS, 2018, p.137.

168 Ibidem, p. 138.

${ }^{169}$ INNERARITY, 2001, p.14 (tradução da autora).

${ }^{170}$ FUÃO, Op Cit., p.54.

${ }^{171}$ INNERARITY, Op Cit., p.13 (tradução da autora).
} 
fronteira, ou à soleira. "Em termos éticos, uma cidade abeta naturalmente toleraria as diferenças e promoveria a igualdade."172

Como a ética da hospitalidade afeta, então, a arquitetura? É necessário compreender de que modo essa dimensão da hospitalidade, de extrema relevância, se desdobra em um componente espacial.

A ética da hospitalidade afeta a arquitetura de muitas maneiras: no programa de necessidades elaborado com base no diálogo com o outro, de pré-dispor um espaço de acolhida; nas aberturas, na concepção dos espaços públicos como lugar de acolhimento das diferenças. ${ }^{173}$

É necessário refletir sobre a forma como a arquitetura acomoda as pessoas. Uma arquitetura acolhedora não é meramente um objeto específico ou um projeto, mas um efeito que resulta da visão dos arquitetos, urbanistas e designers acerca da política do acolhimento ${ }^{174}$. A revitalização da praça Triumfalnaya, projetada pelo escritório Buromoscow (Figura 14) chama atenção para sua dimensão poética. A praça localiza-se no cruzamento da rua principal de Moscou. O concurso, a partir do qual se desenvolve a proposta, tinha como objetivo a revitalização da praça projetada em 1958, que com o passar do tempo, passou a restringir-se a espaço de trânsito, sendo ocupada por estacionamentos. O escritório vencedor propôs a divisão da praça em zonas menores, criação de jardins, planificação do solo e instalação de balanços, ao invés de bancos. A conclusão da intervenção, em 2015, suscitou a transformação do espaço, antes ocupado por carros, em um espaço de estar, cheio de vitalidade decorrente do crescente uso social.

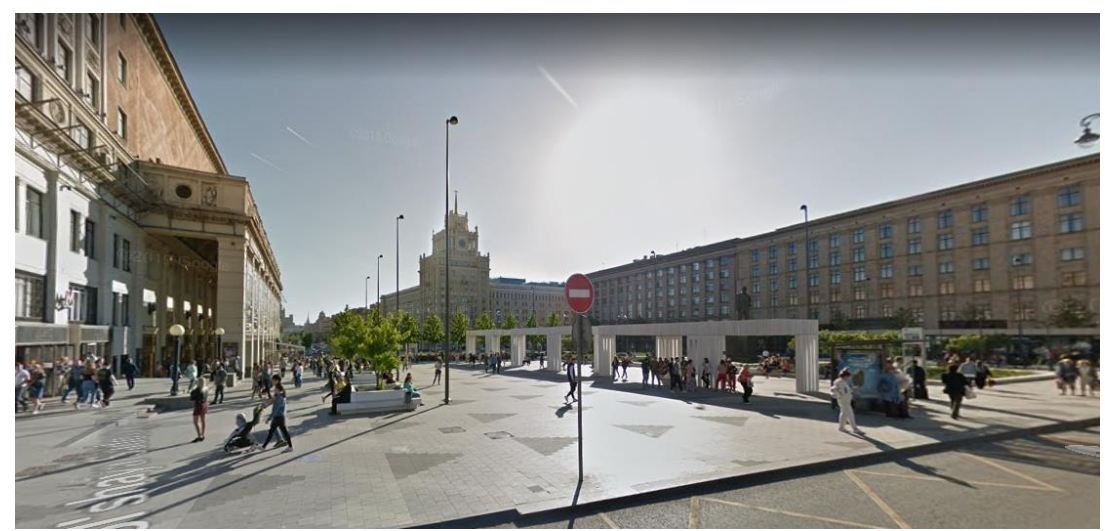

Figura 14: Praça Triumfalnaya

Fonte: Street View Google Earth

${ }^{172}$ SENNETT, 2018, p. 20.
${ }^{173}$ FUÃO, Op Cit., p.64
${ }^{174}$ ARISTARKHOVA, 2021. 


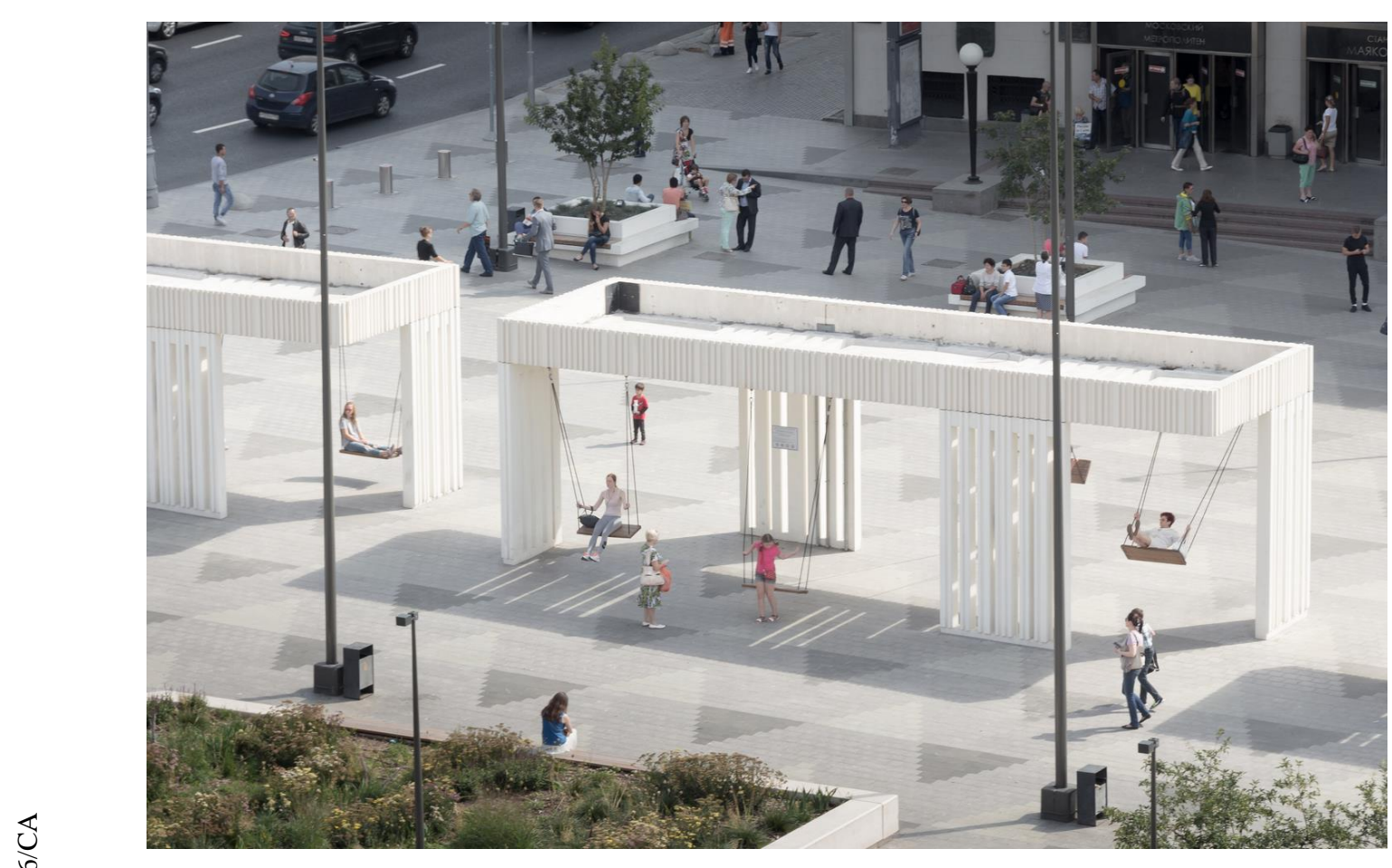

Figura 15: Praça Triumfalnaya

Fonte: https://www.archdaily.com.br/br/887257/praca-triumfalnaya-buromoscow

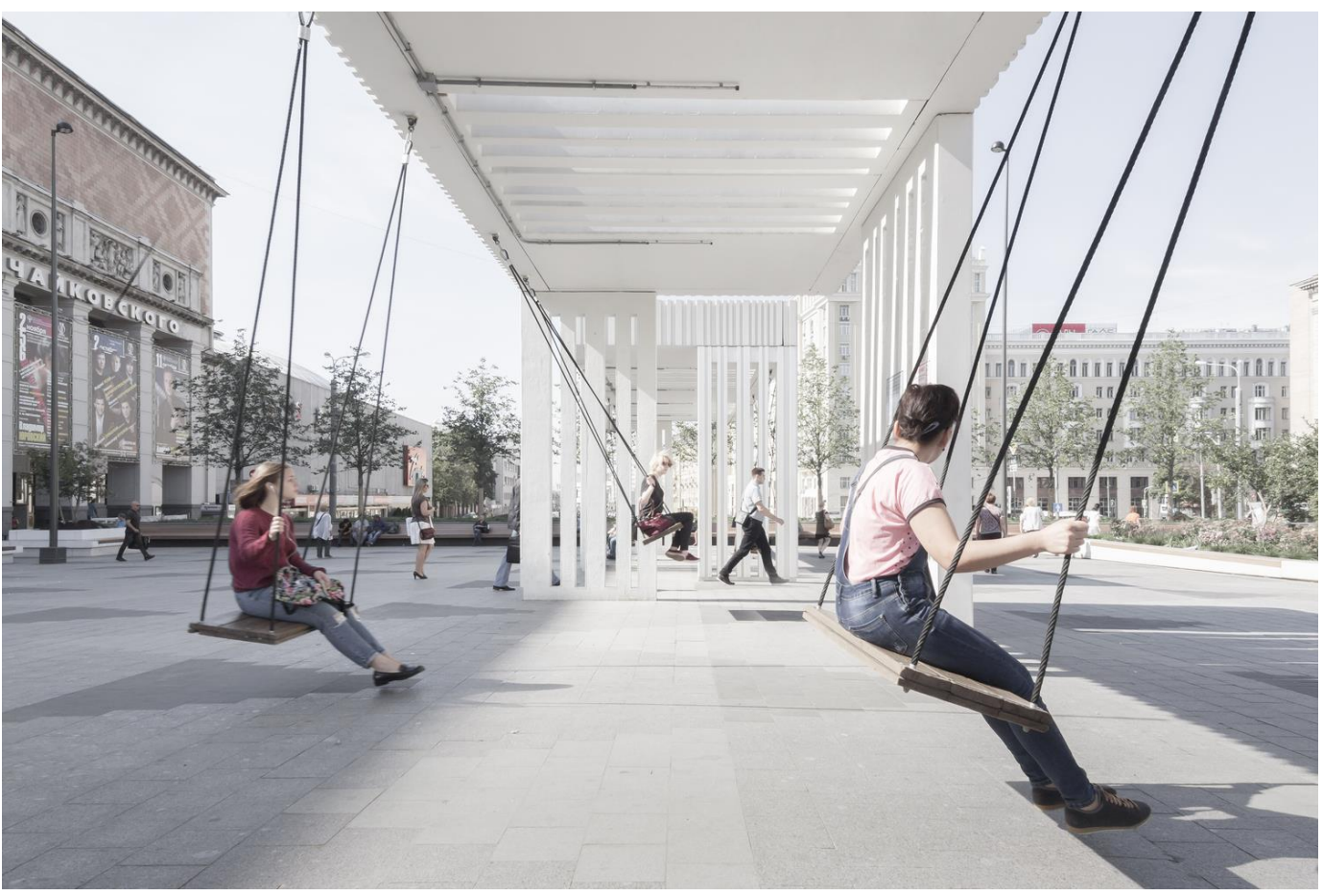

Figura 16: Balanços Praça Triumfalnaya

Fonte: https://www.archdaily.com.br/br/887257/praca-triumfalnaya-buromoscow 
O balanço, neste caso, funciona como um símbolo da experiência espacial. A (po)ética da hospitalidade está majoritariamente ligada, neste exemplo, ao gesto de transpor a sala de estar para o espaço da cidade. $\mathrm{O}$ acolhimento na arquitetura não deve ser aprisionado a interioridade, mas ultrapassar os limites da casa em direção a cidade.

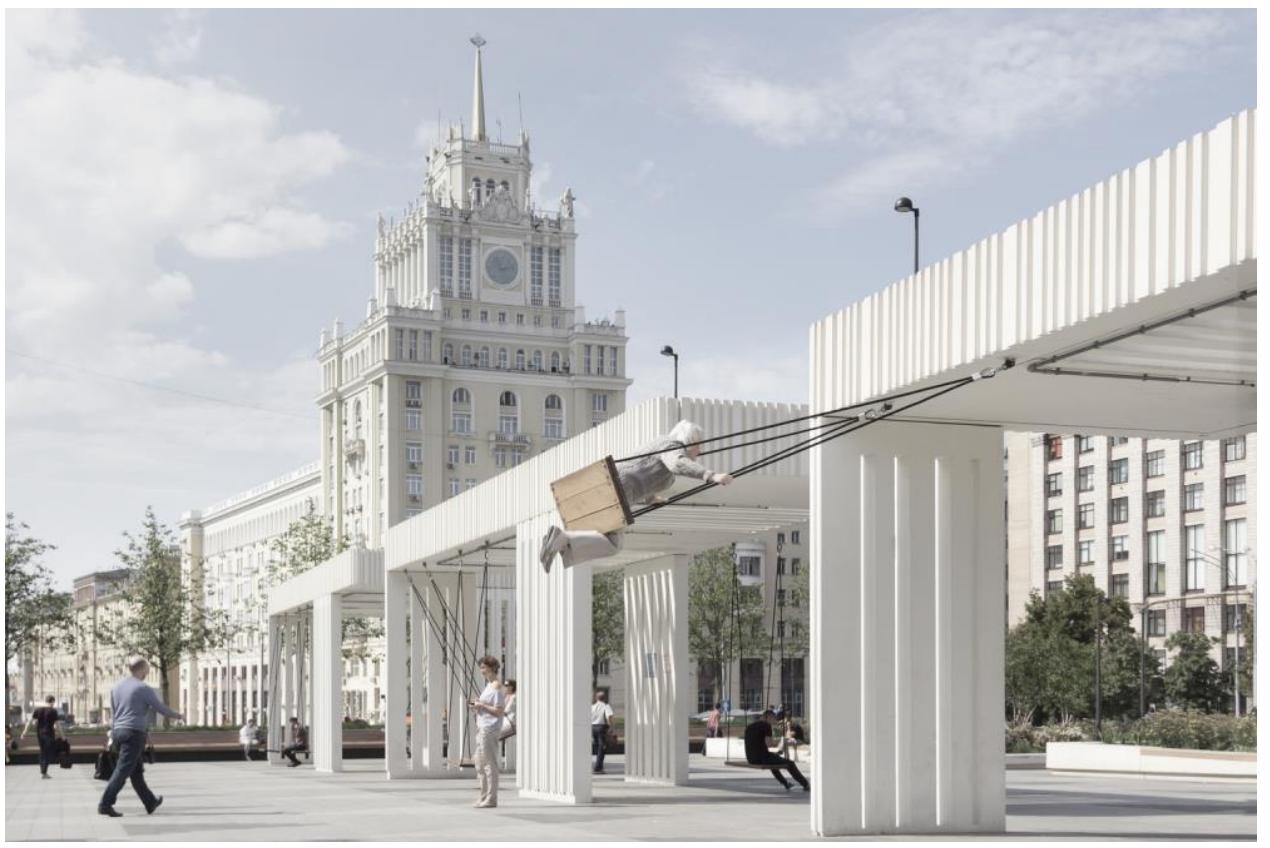

Figura 17: Praça Triumfalnaya

Fonte: https://www.archdaily.com.br/br/887257/praca-triumfalnaya-buromoscow 


\section{Fronteira da hospitalidade}

4.1.

\section{Conceito de fronteira}

Como exposto anteriormente, a construção do habitar não se limita aos espaços construídos. A cidade, com seus diversos elementos que operam de modo complementar são igualmente importantes para a construção desse habitar. Lynch elenca cinco elementos principais que compõem a imagem urbana, seriam eles: vias, limites, cruzamentos, bairros e pontos marcantes. Interessa aqui, investigar esses limites, em uma tentativa de aproximação da hospitalidade. A abertura é condição primordial para a hospitalidade e, dessa forma, observar esse espaço entre construções que determina como se dá a transição entre elas é essencial para a compreensão do acolhimento na arquitetura.

Lynch define os limites da seguinte forma:

Os limites são os elementos lineares não usados nem considerados pelos habitantes como vias. São as fronteiras entre duas partes, interrupções lineares na continuidade, costas marítimas ou fluviais, cortes do caminho-de-ferro, paredes, locais de desenvolvimento. Funcionam, no fundo, mais como referencias secundárias do que como alavancas coordenantes; tais limites podem ser barreiras mais ou menos penetráveis que mantêm uma região isolada das outras, podem ser 'costuras', linhas ao longo das quais regiões se relacionam e encontram. Estes elementos limites, embora não tão importantes como vias, são, para muitos, uma relevante característica organizadora, particularmente quando se trata de manter unidas áreas diversas (...). ${ }^{175}$

Jacobs também apresenta importantes definições acerca desse elemento limítrofe. A autora faz uma clara diferenciação entre fronteiras e limites. As fronteiras exercem uma influência ativa sobre o espaço, enquanto os limites, são elementos passivos ${ }^{176}$. Jacobs, embora não tenha estudado formalmente urbanismo, apresenta uma abordagem de projeto urbano muito importante e pertinente dentro

\footnotetext{
175 LYNCH, 2011, p.58.

176 JACOBS, 2009, p.177.
} 
do tema aqui investigado: olhar a partir da escala humana. Nesse sentido, ela busca observar os fatores que transformam essas fronteiras em barreiras para a escala humana. "O máximo de elementos urbanos deve ser usado para construir um território misto, vivo, e o mínimo possível para a criação desnecessária de barreiras" $" 177$.

A definição de Jacobs vai ao encontro do que aponta Norberg-Schulz acerca da fronteira: "Todo espaço cercado é definido por uma fronteira e Heidegger afirma: 'A fronteira não é aquilo me que uma coisa termina, mas, como já sabiam os gregos, a fronteira é onde aquilo começa a se fazer presente" ${ }^{178}$. O conceito de fronteira nos remete, portanto, a um lugar híbrido, resultado direto da coexistência de diferentes construções e elementos urbanos, com variados usos. O modo como essa fronteira se dilui, definindo o transitar humano pela cidade, é possivelmente o primeiro gesto de hospitalidade atribuído ao espaço.

Esse espaço intermediário, que conduz o habitante entre lugares da cidade, foi explorado por outros autores.

Alguns conceitos da segunda metade do século XX também procuraram dar conta da importância de qualificar essas transições, como chave para eliminar a divisão rígida entre as áreas com diferentes demarcações territoriais. Entre elas podemos destacar o ‘espaço intermediário' de Aldo Van Eych, lugar onde surge uma fusão do público com o privado $[\ldots]^{179}$

A fronteira parece, portanto, estar associada a uma zona limítrofe, com espessura. Não se trata de uma linha imaginária, mas de uma zona com espessura, na qual o habitante transita. A escala humana é, portanto, unidade de medida essencial na caracterização dessas fronteiras. Entender a relação do corpo com os elementos que compõem este espaço entre que conduz e recepciona o indivíduo é o recorte aqui explorado dentro do vasto universo da hospitalidade na arquitetura.

177 Ibidem, p.184

178 NOBERG-SCHULZ, 1980, p.13.

${ }^{179}$ SANSÃO; FAGERLANDE, 2015, p. 6 


\section{2.}

\section{Escala humana e a experiência corporificada do espaço}

Tratar do tema da hospitalidade na arquitetura significa, naturalmente, explorar a experiência humana do espaço. A escala humana é a unidade adequada para mensurar e qualificar o lugar da hospitalidade. A relação do corpo com os elementos físicos, junto a experiência sensorial, é definidora na realização do acolhimento. Ao falar de lugar, estamos falando necessariamente da figura humana e sua relação com o espaço. "Lugar é uma categoria de análise que vai além da escala locacional, pois serve tanto para qualificar as experiências individuais afetivas entre sujeito/espaço, quanto para abranger as espacialidades praticadas socialmente" 180 , sendo primordial, portanto, para assegurar a apropriação desses espaços pelos habitantes.

Além da experiência sensível do ser humano com o espaço, outro fator elementar no âmbito da hospitalidade é a relação entre pessoas, suscitada pela configuração espacial. "Da pólis grega à metrópole contemporânea, a experiencia de lugar na cidade tem sido elevada a uma dimensão prática de criação, transformação e ressignificação do espaço humano, um lugar de gente, de pessoas, de práticas sociais" "181. A escala humana é a escala das relações sociais. Incorporar esse entendimento ao projeto é mais uma das tarefas necessárias na busca de cidades mais humanas. A experiência humana do espaço ganha, nesse sentido, complexidade, ao relevar suas diversas facetas na relação com a hospitalidade.

Torna-se pertinente, nesse sentido, destacar aqui a colocação de Castello acerca do conceito de urbanidade, intimamente vinculado ao conceito de lugar, que se materializa justamente por meio das interações humana no espaço.

A urbanidade é uma característica típica e única do ambiente construído pelo ser humano. É nosso entendimento que a urbanidade é a qualificação vinculada à dinâmica das experiências existenciais conferidas às pessoas pelo uso que fazem do ambiente urbano público, através da capacidade de intercâmbio e de comunicação de que está imbuído esse ambiente. ${ }^{182}$

\footnotetext{
${ }^{180}$ CASTELLO, 2017, p.8.

${ }^{181}$ Idem.

${ }^{182}$ CASTELLO, 2007, p.29.
} 
Para o fortalecimento da dimensão coletiva, o hibridismo programático ${ }^{183}$ se apresenta como possibilidade na configuração do espaço intermediário. Esses usos variados contribuem para a mediação entre espaços de diferentes naturezas. Sob este aspecto, explorar os espaços de caráter público e suas nuances é necessário.

A importância do espaço público certamente não está associada ao fato de ser mais ou menos extenso, quantitativamente dominante ou protagonista simbólico, mas em se referir aos espaços privados fazendo também deles patrimônio coletivo. Dar caráter urbano e público a edifícios e lugares que não seriam privados. ${ }^{184}$

Para o tratamento das fronteiras, de modo atento à experiência humana, revela-se necessário diluir essas barreiras tão características da relação entre público e privado. A cidade formada por ilhas desconectadas empobrece significativamente a experiência espacial. "O fato é que, pelo contrário, a cidade é precisamente o lugar onde o privado pode ser - e frequentemente é - social; tanto quanto o público" ${ }^{\text {185 }}$. Este é um fator chave no entendimento das relações que o conceito de fronteira nos apresenta. Por meio dos graus de privacidade, explorados por Zumthor - e apresentadas anteriormente - como degraus da intimidade que vão definindo os graus de desvelamento do espaço, é possível mediar de modo mais acolhedor as relações entre interior e exterior, entre espaços construídos e entre pessoas.

Ter a escala humana em primeiro plano na configuração do espaço possibilita o estabelecimento de relações de afeto com o lugar e, consequentemente, a sensação de ser acolhido pelo ambiente.

${ }^{183}$ SANSÃO; FAGERLANDE, 2015, p. 7.

${ }^{184}$ SOLÀ-MORALES, 1994, p.23.

${ }^{185}$ Ibidem, p. 25. 
Um exemplo desta relação entre a arquitetura e seu entorno urbano, partindo do conceito de hospitalidade e seu componente afetivo é o edifício Diagonal em Barcelona (Figura 17), L'illa Diagonal, em Catalão, projetado pelos arquitetos Rafael Moneo e Manuel Solà-Morales. Trata-se de um centro comercial que opera como um conector entre os distritos Les Corts e Sarriá-San Gervasi. A estratégia consistiu em projetar um edifício longitudinal que corre paralelo à avenida Diagonal ao longo de toda a quadra, criando uma praça interna (Figura 18), ou miolo de quadra, funciona como conexão entre a avenida Diagonal e os bairros adjacentes. Passagens internas (Figura 19) quebram o volume, gerando circulações fundamentais para a permeabilidade da quadra. As passagens, materializadas por meio de vãos na volumetria, articulam-se com a dinâmica urbana do entorno.

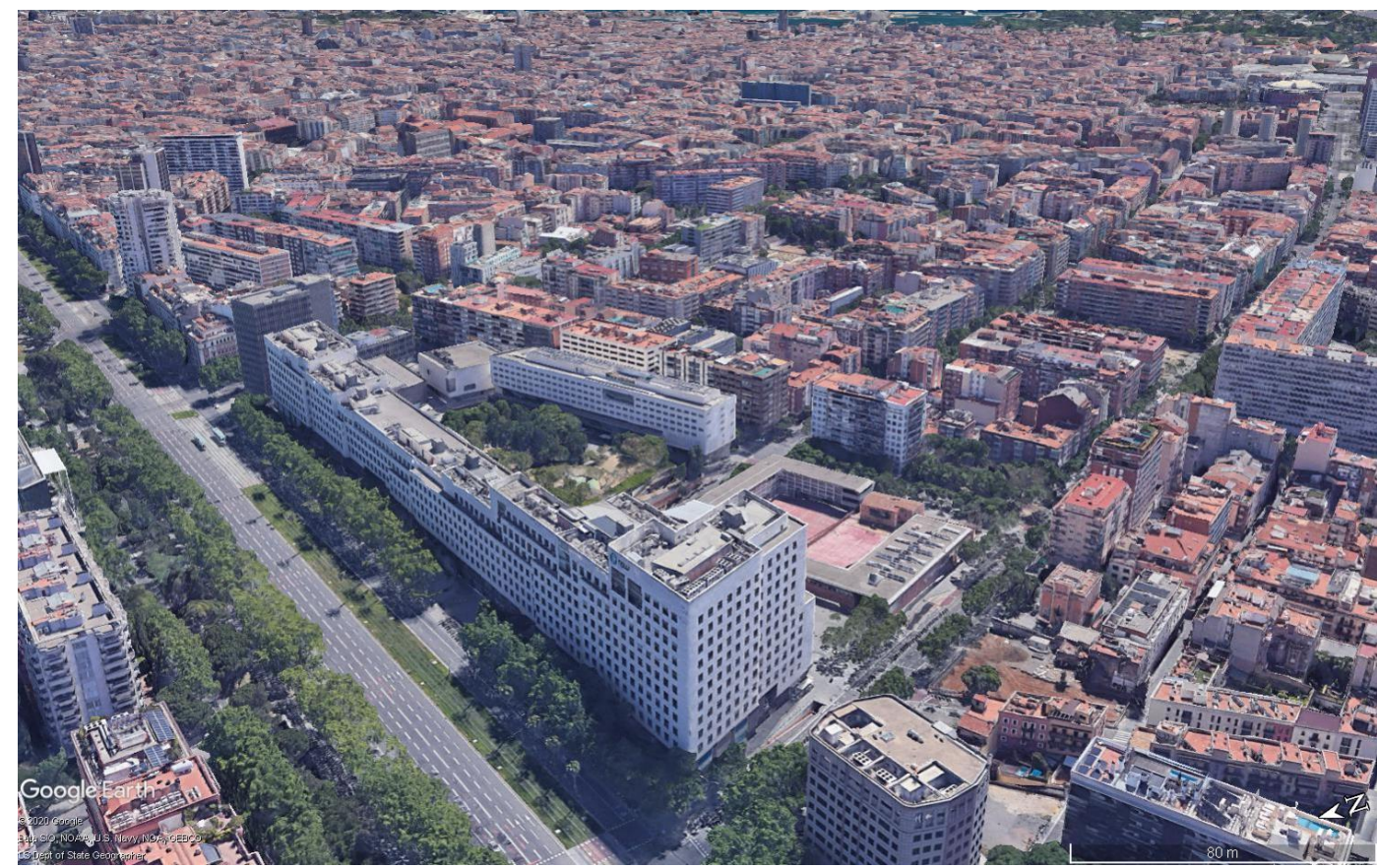

Figura 18: Vista aérea Edifício Diagonal

Fonte: Google Earth 


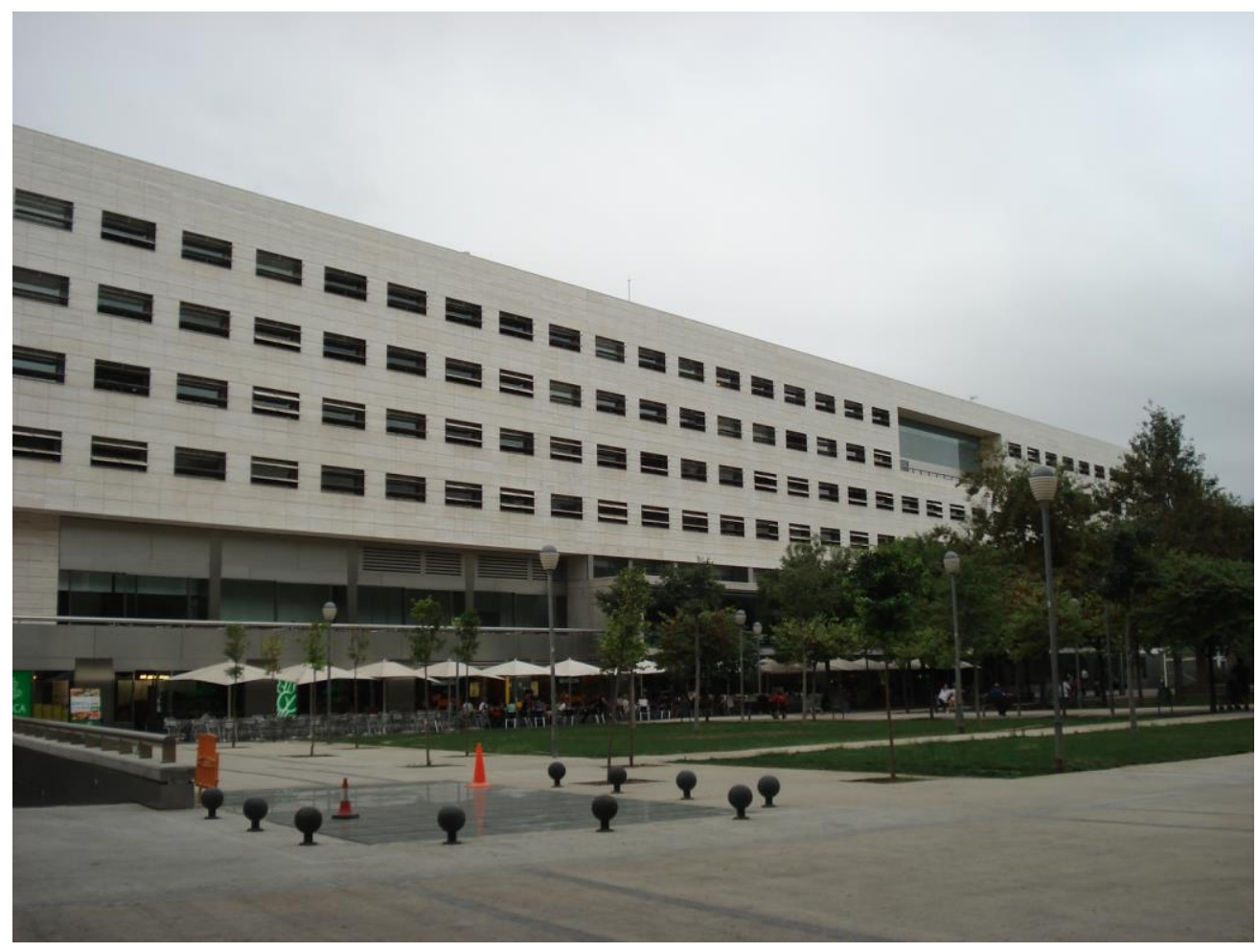

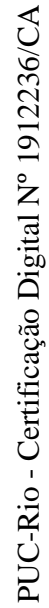

Figura 19: Parque interno no miolo da quadra L'illa Diagonal

Fonte: Fernando Espósito

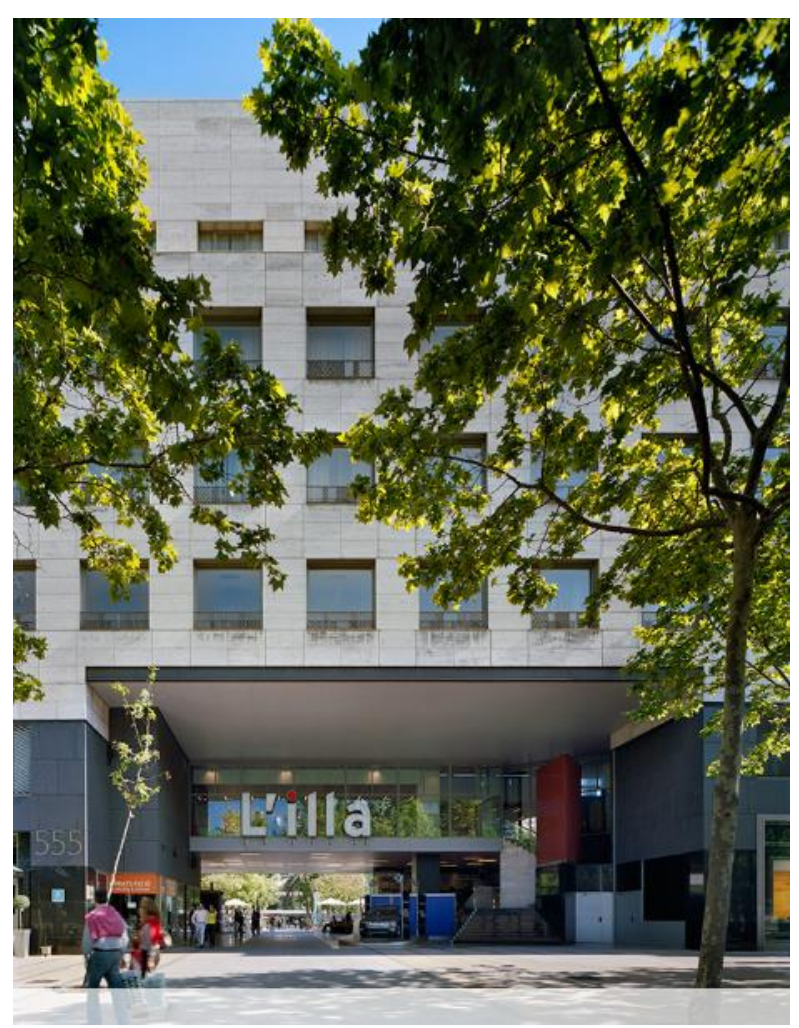

Figura 20: Acesso L'illa Diagonal

Fonte: http://rafaelmoneo.com/proyectos/lilla-diagonal/ 


\section{3.}

\section{Fronteira como lugar da hospitalidade}

Conceber a fronteira como um lugar da hospitalidade demanda um cuidadoso tratamento desses trechos do tecido urbano. Isso, entretanto, não significa a incorporação de estratégias sofisticadas de projeto, como veremos a seguir na análise dos estudos de caso selecionados. A chave está muito mais suavização desses hiatos espaciais do que na realização de projetos notórios.

Gehl, em "Cidades para pessoas", elenca alguns fatores essenciais à vitalidade urbana. Entre eles estão os "espaços de transição suave"186. Segundo o autor, a suavização dessas transições depende principalmente das atividades que se realizam no térreo, ao nível no olhar humano, e o tratamento destas por meio do ritmo, das transparências, das texturas, dos detalhes, da diversidade de funções etc.

Essa diluição das fronteiras é premissa na construção de uma fronteira como lugar da hospitalidade. A permeabilidade desses lugares é condição básica para garantir a abertura tão cara ao acolhimento. Uma fronteira hospitaleira é, portanto, uma fronteira porosa, por onde os habitantes percorrem, em uma contínua articulação entre espaços diversos. Mas é também necessário associar esta configuração aberta ao tratamento do espaço que estimule a vitalidade.

No âmbito da filosofia, como apresentado anteriormente, atribuiu-se a partir da hospitalidade importante significado à soleira, que remete ao lugar de espera, no qual ocorre o primeiro gesto de acolhimento. Pretende-se aqui transpor a soleira para a conceituação da fronteira em âmbito arquitetônico. Hertzberger apresenta a ideia de intervalo, que se relaciona diretamente às noções de diluição e tratamento de fronteiras.

A concretização da soleira como intervalo significa, em primeiro lugar e acima de tudo, criar um espaço para as boas-vindas e as despedidas, e, portanto, é a tradução em termos arquitetônicos da hospitalidade. Além disso, a soleira é tão importante para o contato social quanto as paredes grossas para a privacidade. ${ }^{187}$

A soleira, com seu significado físico e simbólico que remete a esta zona de transição, é um sinônimo da fronteira da hospitalidade. "A soleira fornece a chave

\footnotetext{
${ }^{186}$ GEHL, 2013, p.77.

${ }^{187}$ HERTZBERG, 1999, p.35.
} 
para a transição e a conexão entre áreas com demarcações territoriais divergentes e [...] constitui essencialmente, a condição espacial para o encontro e diálogo entre áreas de ordens diferentes"188. Por meio dela que o público e o privado se relacionam na configuração do espaço coletivo. "Estamos lidando aqui com o encontro e a reconciliação entre a rua, de um lado, e o domínio privado, de outro"189. Observamos a ideia de soleira como uma tradução da fronteira da hospitalidade no Centro Universitário Maria Antonia (Figura 20), por exemplo. O projeto, do escritório Una Arquitetos, garante o caráter hospitaleiro por meio do espaço livre que articula os edifícios em uma intervenção que é posterior a eles, em um projeto de renovação de 2017. Esta zona, que constitui a passagem do espaço da calçada em direção ao interior dos edifícios, é a materialização da soleira, uma fronteira, espessa, de caráter coletivo, que recepciona e acolhe o indivíduo (Figura 21).

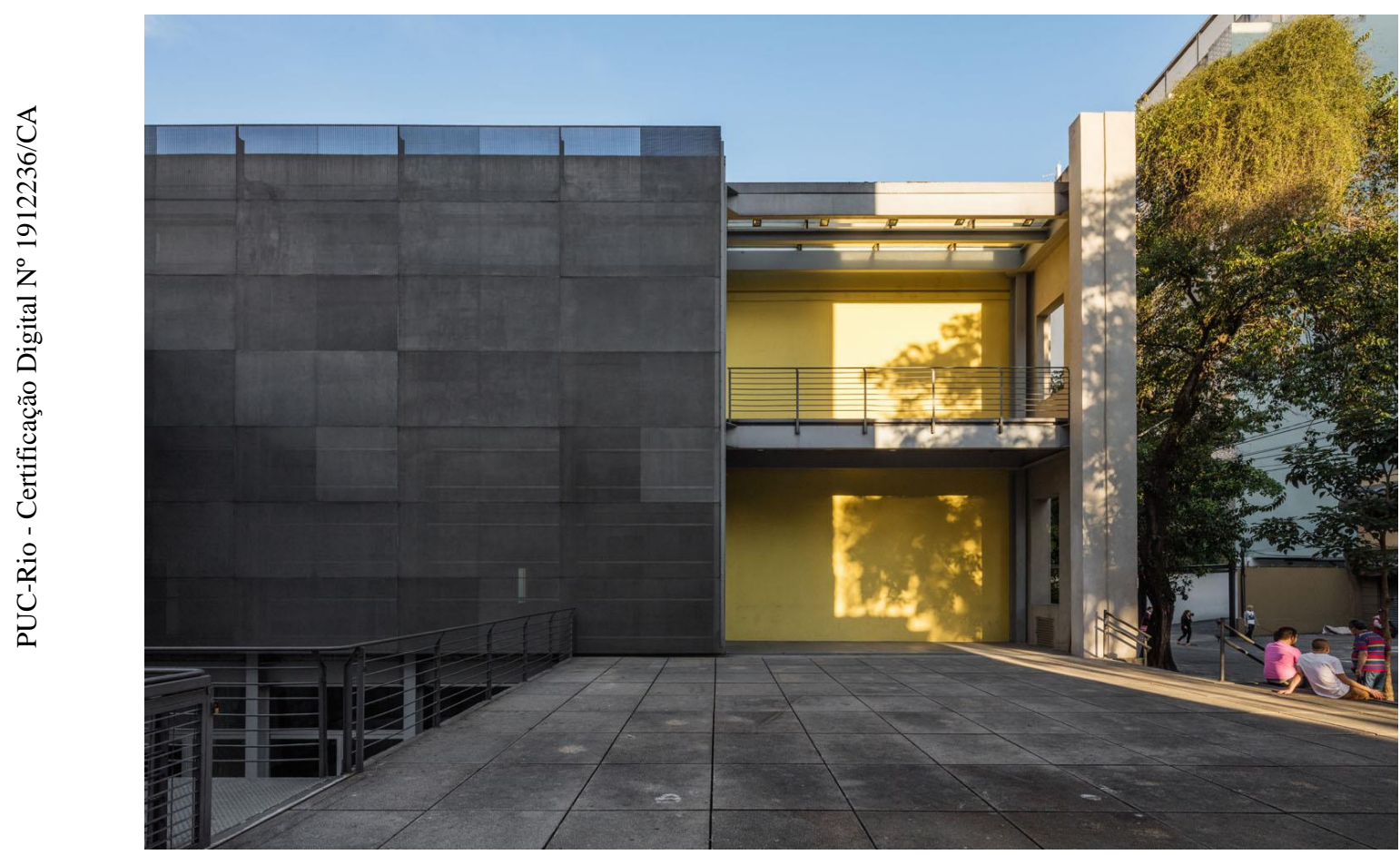

Figura 21: Acesso Centro Universitário Maria Antonia

Fonte: https://www.nelsonkon.com.br/en/centro-universitario-maria-antonia/

${ }^{188}$ Ibidem, p.32

${ }^{189}$ Idem 


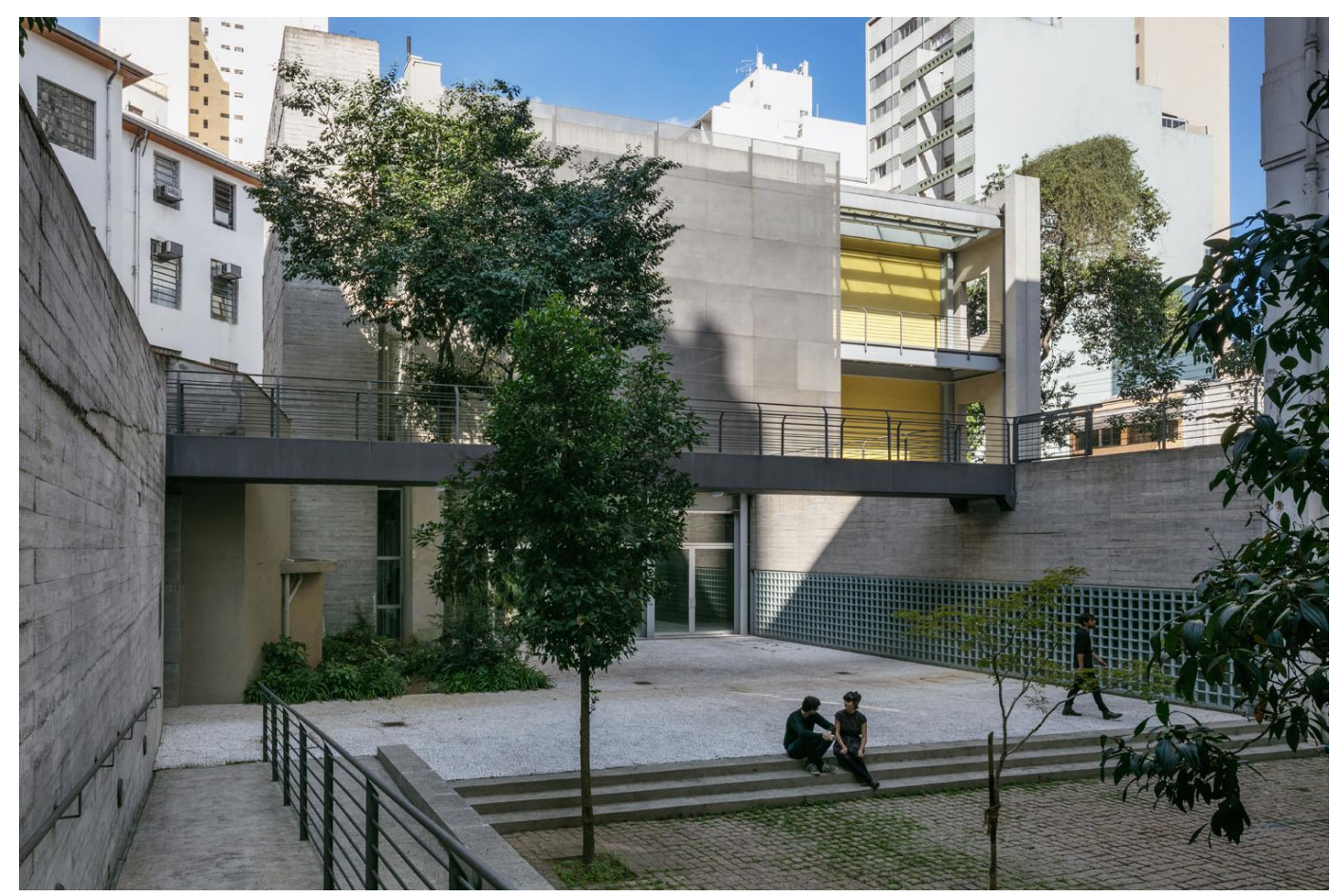

Figura 22: Praça interna do Centro Universitário Maria Antonia Fonte: https://www.nelsonkon.com.br/en/centro-universitario-maria-antonia/

O centro universitário Maria Antonia delimita dentro da cidade fronteiras da hospitalidade pois, a praça interna que faz a intermediação entre a calçada e o interior do edifício, torna este um lugar aberto, que acolhe o habitante, de modo que os limites entre o interior e o exterior do lote do centro universitário se diluem em um gesto de acolhimento em relação ao habitante.

Esse tratamento da soleira, em busca de uma fronteira como lugar da hospitalidade, reforça a ideia de cidade e arquitetura como mesmo projeto. Essa zona limítrofe, espessa, denominada aqui como fronteira da hospitalidade, fornece o aparato físico e tratamento do espaço necessários à habitabilidade, estimulando a concentração de pessoas e interações sociais. É na fronteira da hospitalidade onde se realiza o primeiro gesto de acolhimento.

Sob o aspecto das fronteiras, é válido desenvolver um paralelo com o Edifício Argentina (Figura 22), no Rio de Janeiro. Localizado em Botafogo, este edifício estabelece, em relação ao seu contexto urbano, a relação de abertura e integração, tão cara à hospitalidade. 


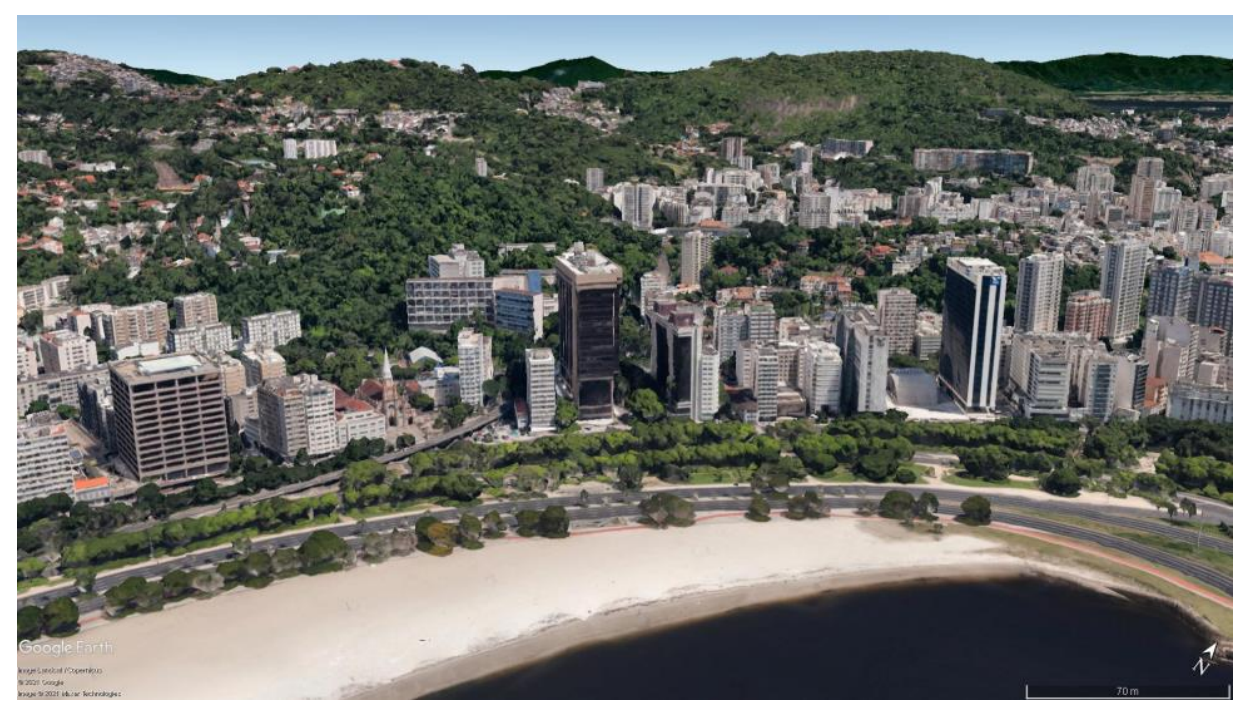

Figura 23: Edifício Argentina e contexto urbano

Fonte: Google Earth

Por meio de uma implantação que conforma uma rua peatonal, a abertura para o interior do lote é garantida, área que acaba funcionando como passagem entre as vias adjacentes à quadra do edifício (Figura 23).

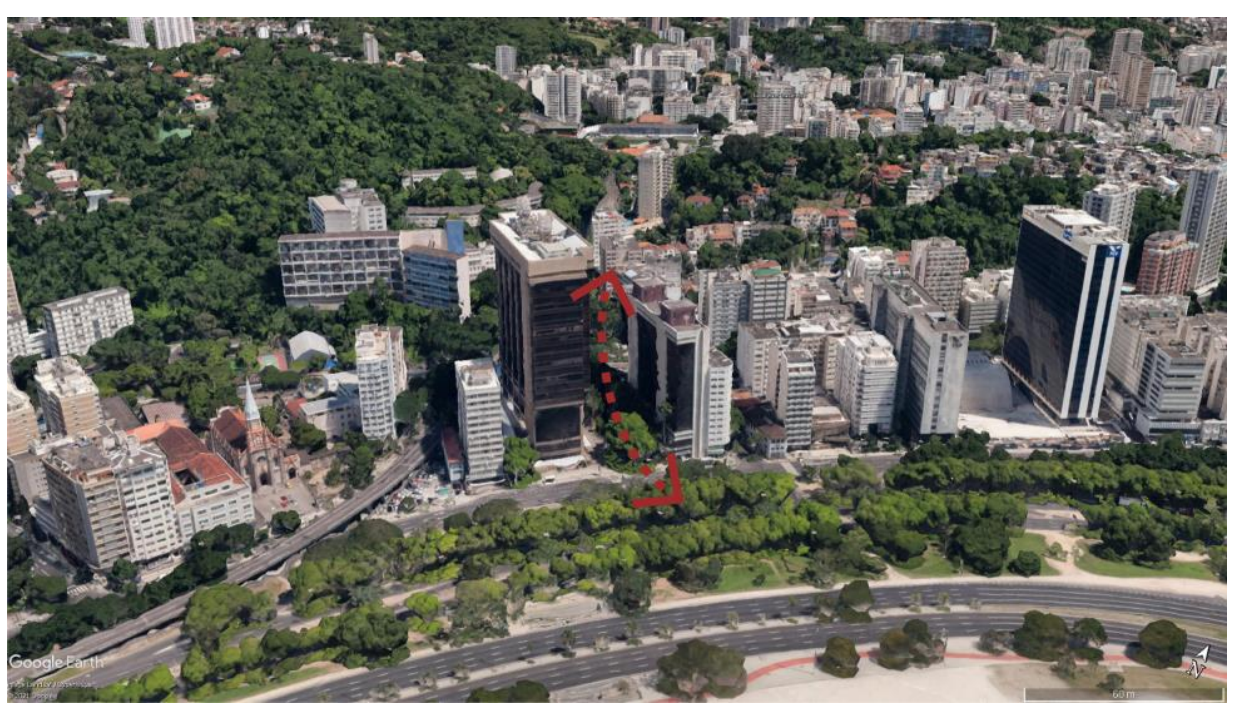

Figura 24: Integração gerada pela implantação Edifício Argentina Fonte: Google Earth 
A via interna é composta por alguns elementos importantes (Figura 24) para a conformação de um lugar da hospitalidade, dentre eles: presença de área sombreada em decorrência da vegetação no eixo central, presença de estabelecimentos comerciais, garantindo vitalidade e presença constante de pessoas, e existência de dispositivos para permanência dos habitantes, como bancos e mesas.

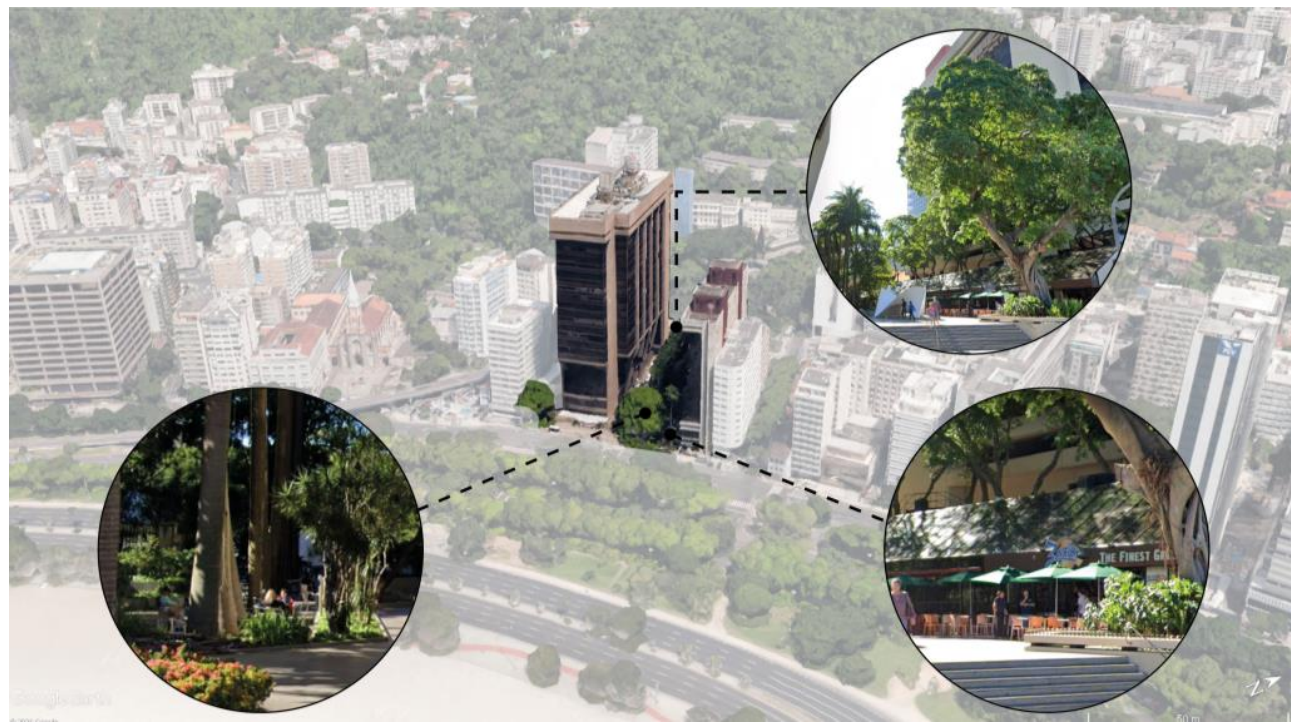

Figura 25: Hospitalidade da via peatonal Ed. Argentina Fonte: Elaborado pela autora

A implantação proposta para este edifício faz com que a calçada atravesse o lote, gerando um espaço convidativo para os habitantes. É interessante o paralelo com o edifício Diagonal em Barcelona, principalmente quando abarca-se a questão do edifício privado como espaço coletivo. Tornar o espaço privado tão social quanto o público, por meio de estratégias de projeto que promovam a abertura para espaços de convívio habitáveis, é primordial para a construção de uma cidade hospitaleira. 


\section{Observação do espaço habitado}

\section{1.}

\section{Ferramentas de análise da hospitalidade}

Para uma análise baseada nos conceitos explorados neste trabalho se mostrou adequada a observação do espaço habitado estruturada a partir de um percurso por espaços da cidade do Rio de Janeiro, não pautado exclusivamente na análise de obras emblemáticas, mas de lugares que abriguem o convívio cotidiano. Essa metodologia de análise está alinhada ao tema de pesquisa do trabalho que procura explorar mais a fundo as relações de afeto que um lugar hospitaleiro desperta no habitante.

Ao nos deslocarmos em nossas errâncias pela cidade, ocorre uma captura incessante de impressões e sensações que desencadeiam um processo de triagem de nossas respostas afetivas proporcionadas pela incessante [re]organização de referências memoriais. ${ }^{190}$

A pandemia causada pela disseminação do COVID-19 impactou profundamente o modo como nos relacionamos com o espaço das nossas casas e da cidade. A necessidade de quarentena evidenciou a necessidade do ambiente externo como continuidade do habitar humano. Se por um lado, foi necessário um olhar prolongado para o interior do ambiente construído, por outro, se fortalece a importância da interação com o ambiente externo, não só pela ambiência em si, mas também pelos encontros e trocas sociais suscitados por ela. Esse cenário destaca ainda mais a relevância da reflexão acerca de espaços mais hospitaleiros, seja no interior dos edifícios ou fora deles.

${ }^{190}$ DUARTE, 2016, p.71. 
A pandemia, além de fomentar a reflexão acerca da hospitalidade, impôs uma nova condição de aproximação dos estudos de casos. A metodologia precisou ser adequada a um contexto de quarentena, o que, entretanto, potencializa outras ferramentas de análise. O exercício de análise baseou-se na espacialização da memória, na qual, espaços habitados da cidade do Rio de Janeiro são revisitados por meio de fotografias e croquis no intuito de identificar elementos físicos e imateriais que garantem hospitalidade para aquele lugar. $\mathrm{O}$ que em um primeiro momento se apresentou como uma barreira, que impedia visitas presenciais regulares aos espaços analisados, em um segundo momento revela sua potencialidade. As ferramentas de aproximação e projeto do arquiteto se potencializam neste momento. Croquis inicialmente destacam alguns elementos chave, relativos à construção do lugar, que em seguida são mensurados, avaliando as relações de proximidade geradas.

Nesse sentido, a memória adquiri um importante papel para a metodologia de análise aqui aplicada. Este é o ponto de partida da análise: recordar espaços habitados, buscando reconhecer gestos de hospitalidade presentes nesses lugares. Vale pontuar, portanto, a origem da palavra recordar. "A raiz etimológica da palavra "coração", ou seja, cor ou cordis, deu origem a várias palavras da língua portuguesa"191. "Recordar", por sua vez, significa "trazer de novo ao coração". Como já foi aqui exposto, o afeto é um aspecto fundamental quando avaliamos a hospitalidade do lugar. A relação de afeto entre habitante e lugar criam memórias que não poderiam ser deixadas de lado em uma análise pautada a partir da experiência humana do espaço.

Propõe-se, dessa forma, categorias de análise para explorar espaços cotidianos, não necessariamente fruto de projetos notórios, na busca elementos que vão visibilizando os conceitos aqui explorados. Adota-se, para a leitura dos estudos de caso, uma análise, a partir de observação não participante, estruturada a partir das seguintes ferramentas principais:

\footnotetext{
${ }^{191}$ Origem etimológica das palavras disponível em:

https://www.dicionarioetimologico.com.br/coracao/, Acessado em 29 de janeiro de 2021
} 


\section{Levantamento de dados}

Primeiramente, é necessário pontuar que contexto não é simplesmente um cenário. Ele possui não apenas uma dimensão física, mas também histórica, política social e cultural. "Não é nem o seu 'cenário', nem o seu 'pano de fundo', nem a sua 'explicação', mas antes o contexto e a obra arquitetônica configuram juntos a noção de 'lugar', que contém em si um espaço humanamente habitável dotado de significado" $" 192$. A primeira ferramenta de análise procura levantar as práticas sociais locais, identificando a dinâmica dos espaços em diferentes períodos da evolução do lugar.

Nesse sentido, é válido investigar inicialmente o contexto da cidade do Rio de Janeiro para os estudos de caso selecionados. A cidade que abriga determinado lugar, seus costumes sociais e aspectos culturais são determinantes no modo de habitar o espaço. Em um cenário carioca, podemos inferir por exemplo que a presença de outras pessoas é, também, fator relevante na construção do lugar da hospitalidade. Além de contribuir para a sensação de segurança, a presença de pessoas estimula o convívio social.

A reunião de dados relativos à evolução do lugar permite a melhor compreensão não só do contexto físico, histórico e social, mas também a compreensão da evolução urbana que delimita as fronteiras espaciais que compõem o espaço. A respeito do contexto físico da cidade do Rio de Janeiro, o clima traz também algumas variáveis importantes para a realização da hospitalidade na arquitetura. Como será observado adiante, a presença de árvores ou coberturas seja por meio de marquises ou do vão livre arquitetônico - que gerem áreas de estar sombreadas compõe as estratégias de acolhimento do lugar.

O levantamento de dados, como ponto de partida da metodologia aplicada na análise dos estudos de caso, permite ainda o registro das informações acerca da intensidade de uso dos espaços e das recordações oriundas da memória afetiva em relação ao lugar analisado.

${ }^{192}$ ESPÓSITO, 2011, p.25. 


\section{Croquis}

Para uma compreensão mais profunda dos gestos de acolhimento do espaço, lançou-se mão de uma importante ferramenta projetual: o croqui. O desenho como instrumento de análise, dimensionamento e humanização do espaço é inerente à prática arquitetônica. Optou-se, portanto, por explorar, por meio de croquis, a microescala que compõe os lugares selecionados. Fracionar tais contextos em pequenas ambiências possibilitou a aproximação dos componentes e estratégias geradores de hospitalidade. A partir de croquis sobre imagem, foram levantados os elementos chave do lugar da hospitalidade e figuradas as possíveis vivências daqueles espaços.

O croqui é uma das ferramentas de humanização do espaço utilizadas na profissão do arquiteto, e por isso se mostra tão pertinente para esta investigação. É por meio dela que o arquiteto imagina as possíveis formas futuras de habitar o espaço, aproximando o objeto proposto às relações humanas criadas a partir dele. O croqui permite prefigurar, utilizar a dimensão humana como unidade de medida e atribuir gestos de hospitalidade ao projeto. Portanto, ela pode operar, tanto na fase de idealização do projeto como em uma fase analítica posterior, como neste caso, como uma ferramenta de estudo que mobiliza as percepções e as dimensões mais subjetivas do sujeito (sensoriais e afetivas), fundamentais na compreensão de uma arquitetura e uma cidade hospitaleira.

Dentro da metodologia proposta pela investigação, o croqui auxilia na análise da fluidez em zonas de alternância entre diferentes espaços, avaliando a abertura dessas fronteiras. Esta ferramenta contribui também para a imaginação das possíveis formas de habitar os lugares analisados. A partir deste ponto, permite-se compreender a flexibilidade desses espaços em tolerar diferentes formas de apropriação, de modo a adaptar-se às diferentes demandas humanas. Este processo auxiliará a identificação, previamente iniciada no levantamento de dados, dos elementos que contribuem para a habitabilidade.

A hospitalidade é afetada ainda pela temporalidade. Cada contexto apresenta uma dinâmica específica e se apresenta, portanto, mais ou menos hospitaleiro, para cada pessoa, de acordo com seus ciclos de atividade. Ainda que a estrutura física seja a mesma, as atividades realizadas e o nível de interação social estimulado por elas afetará diretamente as noções de hospitalidade de modo individual. Tais atividades são diversas e mudam ao longo de um determinado 
período, por exemplo entre a manhã e tarde de um mesmo lugar, entre um dia laboral e final de semana ou, inclusive, ao longo de um mês, trimestre ou ano. O croqui funciona aqui também como ferramenta de visualização desses diferentes tempos. De acordo com práticas sociais locais, se estabelece uma temporalidade da intensidade de interação social, tornando o espaço mais ou menos hospitaleiro de acordo com o período observado.

\section{Diagramas}

Montaner apresenta os diagramas como recursos capazes de traduzir as diversas maneiras de enxergar a realidade e os atos humanos. Propõe-se para esta investigação, portanto, desdobrar os gestos hospitaleiros, identificados por meio dos croquis, em uma classificação a partir das escalas da hospitalidade. A partir desse exercício é possível verificar que um lugar da hospitalidade depende que as escalas sejam vistas de modo coextensivo. Não é possível uma hospitalidade da arquitetura que se dê exclusivamente em uma única escala.

O digrama como ferramenta permite, dessa forma, relacionar a investigação teórica com a análise dos espaços habitados. A partir dele é possível enxergar um desdobramento direto da pesquisa teórica sobre a análise dos estudos de caso, em uma aplicação dos conceitos investigados sobre percursos na cidade do Rio de Janeiro. Portanto, dentro da metodologia utilizada, o diagrama funciona como ferramenta para sintetizar relações identificadas, caracterizando o caráter das fronteiras investigadas. Além disso, atua como ferramenta de mapeamento dos elementos do acolhimento, anteriormente identificados, oferecendo uma visão sintética das dimensões da hospitalidade que compõem o espaço. Propõe-se ainda a utilização do diagrama para identificação da escala em que cada elemento opera (muitos deles operam em mais de uma escala), revelando como as escalas da hospitalidade operam de modo integrado no acolhimento do habitante em cada espaço. O diagrama pode ser utilizado na investigação do acolhimento como ferramenta para identificar as diferentes intensidades de uso social em cada trecho do lugar analisado. Por meio dele é possível sintetizar e expressar, de certo modo, o pulsar do espaço analisado. Enquanto ferramenta, permite registrar a ausência de constância de uma percepção hospitaleira do espaço, pois um lugar não se define apenas por sua estrutura física, mas também pela sua dinâmica social. Os trechos de intensificação do convívio social são os trechos de dilatação da fronteira. 
4. Desenhos de detalhe

Esta ferramenta metodológica nos revela dimensões e graus de proximidade referentes ao acolhimento do espaço. Por meio dela é possível pontuar as dimensões dos elementos destacados e informar a distância entre eles. Em um lugar da hospitalidade, tais dimensões precisam ser adequadas às dimensões humanas. Este aspecto é fundamental na compreensão da experiência corporificada do espaço. Estas dimensões são determinantes na delimitação da proximidade entre as pessoas e a relação delas com o lugar.

Propõe-se a partir dessa ferramenta o dimensionamento dos vãos que delimitam a abertura de um espaço, contrapondo-os às dimensões humanas. Além disso, o desenho em escala aproximada se aplica aos elementos da hospitalidade identificados, no intuito de compreender sua relação com as dimensões humanas. Mensurar tamanhos e distâncias é primordial para uma análise mais precisa, onde dimensões delimitam relações de proximidade entre pessoas e a relação delas com o lugar.

\section{Colagem}

A metodologia de análise conta ainda com exercícios de colagem. "O espaço e as formas do acolhimento partem do sentido de acolhimento contido na palavra "cola""193. A cola simboliza, nesse sentido, o ato de aglutinar o que estava disperso anteriormente. A colagem se revela, a partir dessa significação, uma ferramenta adequada para análise da hospitalidade. Ela mobiliza a imaginação acerca do lugar e expressa um modo de ler e interpretar a realidade. Demanda uma postura de transpor-se para o lugar do outro na tentativa de figuração das possibilidades de vivência daquele espaço.

Paese desenvolve a "Cartografia da Hospitalidade" na busca de atender a demanda de criação de leituras espaciais que resgatem a complexidade humana e o sentido de coexistência da urbe. De acordo com a autora,

a cidade vai muito além do que aquela que é vendida nas representações contidas nos mapas oficiais. As cartografias convencionadas para esses fins determinam, comunicam e limitam o desenvolvimento das potências de acolhimento encontradas nos espaços públicos por não representá-las em sua real dimensão subjetiva ${ }^{194}$

\footnotetext{
${ }^{193}$ FUÃO, 2015, p.93.

${ }^{194}$ PAESE; MARIANO; MOREIRA, 2018, p.1553
} 
Vale pontuar que a colagem é também uma ferramenta amplamente utilizada em arquitetura para prefigurar o modo como as pessoas poderão habitar dado espaço. É a partir dessa vertente que se explora a colagem nesta pesquisa: reconfigurando as vivências conhecidas daquele lugar. O resultado é a aglutinação visual de variadas vivências que não esgotam as possibilidades daquele espaço. Esse exercício é consideravelmente conduzido pelas memórias pessoais que aquele contexto traz.

Enquanto ferramenta metodológica, propõe-se a utilização da colagem para trazer à tona a dimensão subjetiva de um espaço aberto fisicamente, imaginar possíveis formas de habitar este lugar e representar memórias individuais e coletivas, por meio da aproximação dos sentimentos em relação ao lugar. Esta ferramenta opera em uma aproximação da dimensão subjetiva do acolhimento. Tal exercício, quando aplicado a partir dos diferentes ciclos espaço-temporais, pode gerar resultados variados, já que um mesmo lugar possui frequência e vitalidade que ariam continuamente. Um lugar não é estático e por isso inúmeras colagens podem expressá-lo a partir de diferentes óticas do acolhimento.

A pesquisa, que partiu de uma conceituação teórica em paralelo com importantes obras arquitetônicas que ilustravam de alguma forma as questões levantadas, se conclui tendo como estudos de caso, espaços ordinários do cotidiano carioca, em uma busca da hospitalidade que se dá, inclusive, no "infraordinário" 195. Georges Perec explora a ideia de infraordinário na sua vivência, como aquilo que é trivial, cotidiano, evidente, comum e ordinário.

Este olhar em direção ao infraordinário revela que a hospitalidade não se realiza exclusivamente em grandes obras arquitetônicas, mas por meio de pequenos gestos que permitem uma experiência corporificada do espaço. Nesse sentido, a investigação interroga o habitual, em busca de gestos de acolhimento presentes no espaço cotidiano da cidade. Gestos que são expressão de empatia com o habitante.

Os pequenos gestos do acolhimento não dependem de arquitetos renomados, mas exercem impacto primordial na vivência diária que se tem na cidade. A relevância dos pequenos gestos em uma hospitalidade na arquitetura reforça a ideia de que a microescala explica a macroescala. Um ambiente atento à

195 PEREC, 2010. 
escala humana em seus detalhes gera um contexto mais hospitaleiro. Pequenas intervenções geram grandes impactos na vida das pessoas, o que nos remete à ideia de mínima intervenção com máxima melhoria.

Neste ponto encontra-se a principal justificativa para escolha dos estudos de caso. Espaços comuns, que compõem a vivência da cidade do Rio de Janeiro, são analisados em busca de gestos da hospitalidade, no intuito de corroborar com a ideia defendida por Fuão de que a hospitalidade está em tudo. Embora sejam lugares ordinários na vida dos habitantes, vale ressaltar que ambos estão localizados na zona sul da cidade do Rio de Janeiro. Esta localização geográfica, por si só, levando em consideração o contexto de evolução da cidade, garante maiores investimentos em infraestrutura e manutenção desses locais, primordiais à vida na cidade. As fronteiras espaciais presentes nas demais zonas da cidade são, com frequência, impactadas pela carência de investimentos e até mesmo de um olhar em direção a elas. 


\section{2.}

\section{Espaços investigados}

\subsection{1.}

\section{Praça São Salvador - RJ}

A praça São Salvador, localizada no bairro de laranjeiras, na zona sul do Rio de Janeiro, é lugar fundamental para uma investigação acerca da experiência urbana carioca. A reforma urbana do prefeito Pereira Passos, morador de laranjeiras, que se deu no início do século XX, teve como principais preocupações "melhorar as condições sanitárias, equipar e embelezar a cidade na busca pela modernização. Nesse contexto, foram realizadas a urbanização da Praça São Salvador, as árvores e a pavimentação de várias ruas do bairro"196. A conformação atual da praça (Figura 26), no entanto, é resultado também de uma revitalização oriunda do programa Rio Cidade, em 1996, sob a responsabilidade do arquiteto Jorge Mario Jáuregui. Foi este projeto que deu origem a configuração que reconhecemos hoje: "três zonas com limites espaciais bem definidos, onde a parte central, mais livre, é dominada pelo chafariz histórico e as laterais são protegidas por um parapeito que é utilizado por quem frequenta o local. como banco e suporte" 197 .

A praça é amplamente conhecida pela variedade de atividades e eventos relacionados a música. Bloco de carnaval, roda de choro, roda de samba, forró, feira de artesanato são alguns dos encontros que compõem a agenda local. Todo esse contexto, junto a sua estrutura espacial, permite que essa seja uma praça amplamente utilizada do cotidiano carioca.

${ }^{196}$ ESPOSITO; SANSÃO; ZIGONI, 2016.

${ }^{197}$ Idem 


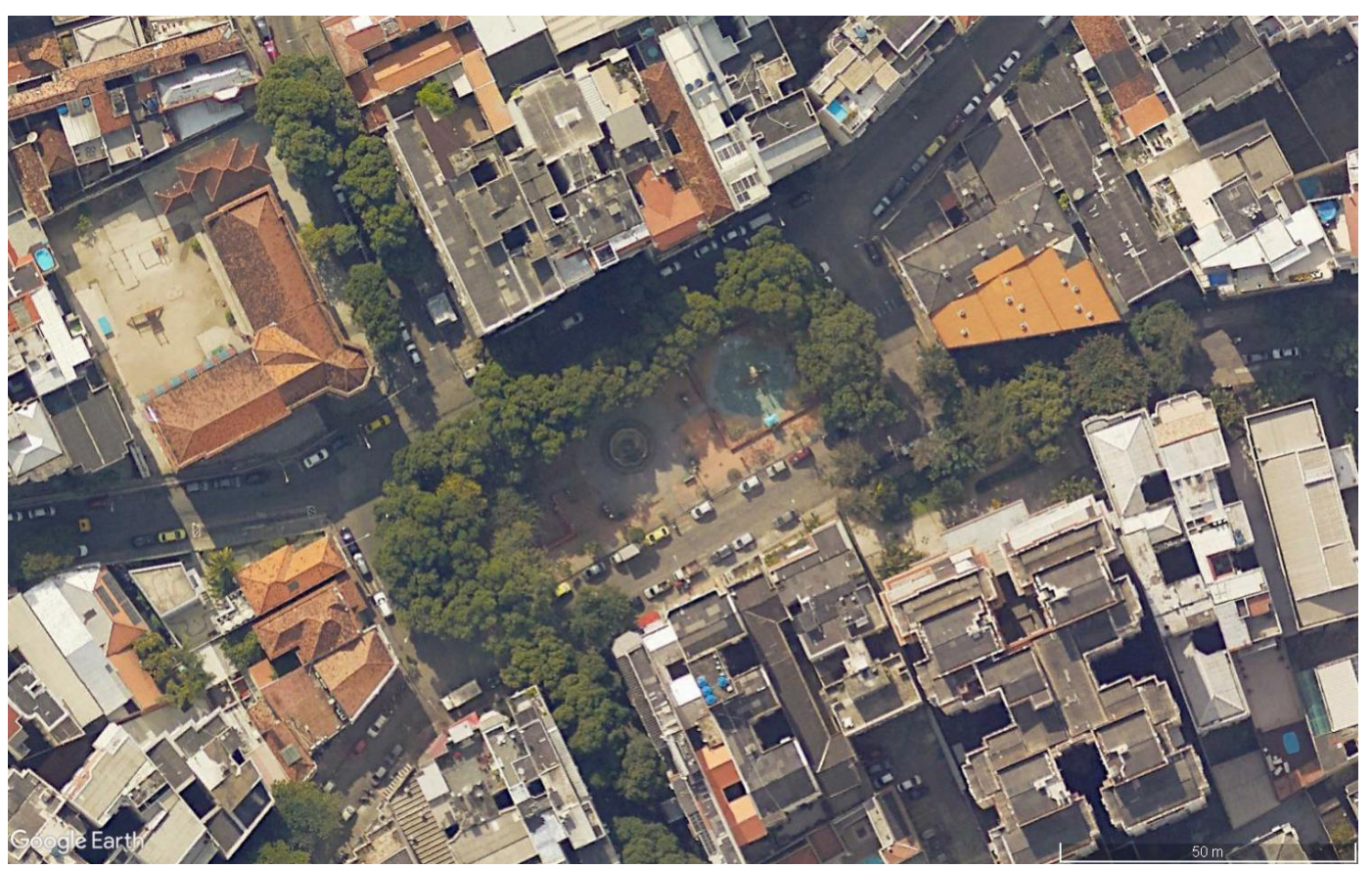

Figura 26: Foto aérea Praça São Salvador

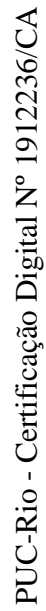

Fonte: Google Earth

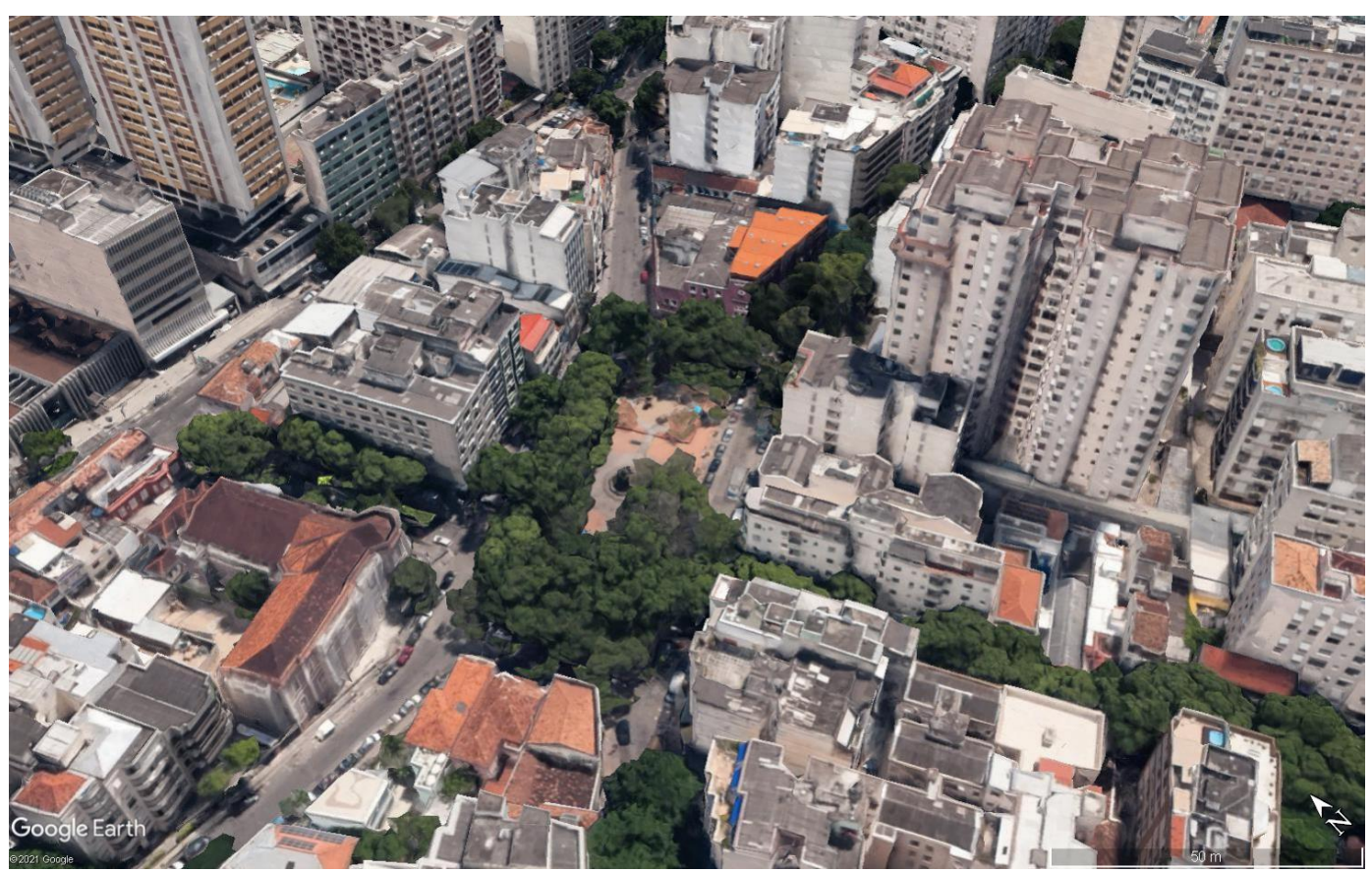

Figura 27: 3D fotorrealista Praça São Salvador e imediações

Fonte: Google Earth 
A seguir, por meio de croquis (Figura 28), destacam-se algumas dimensões que se considera relevantes para a realização da hospitalidade nesse lugar. Esses elementos serão explorados de modo individual a seguir.

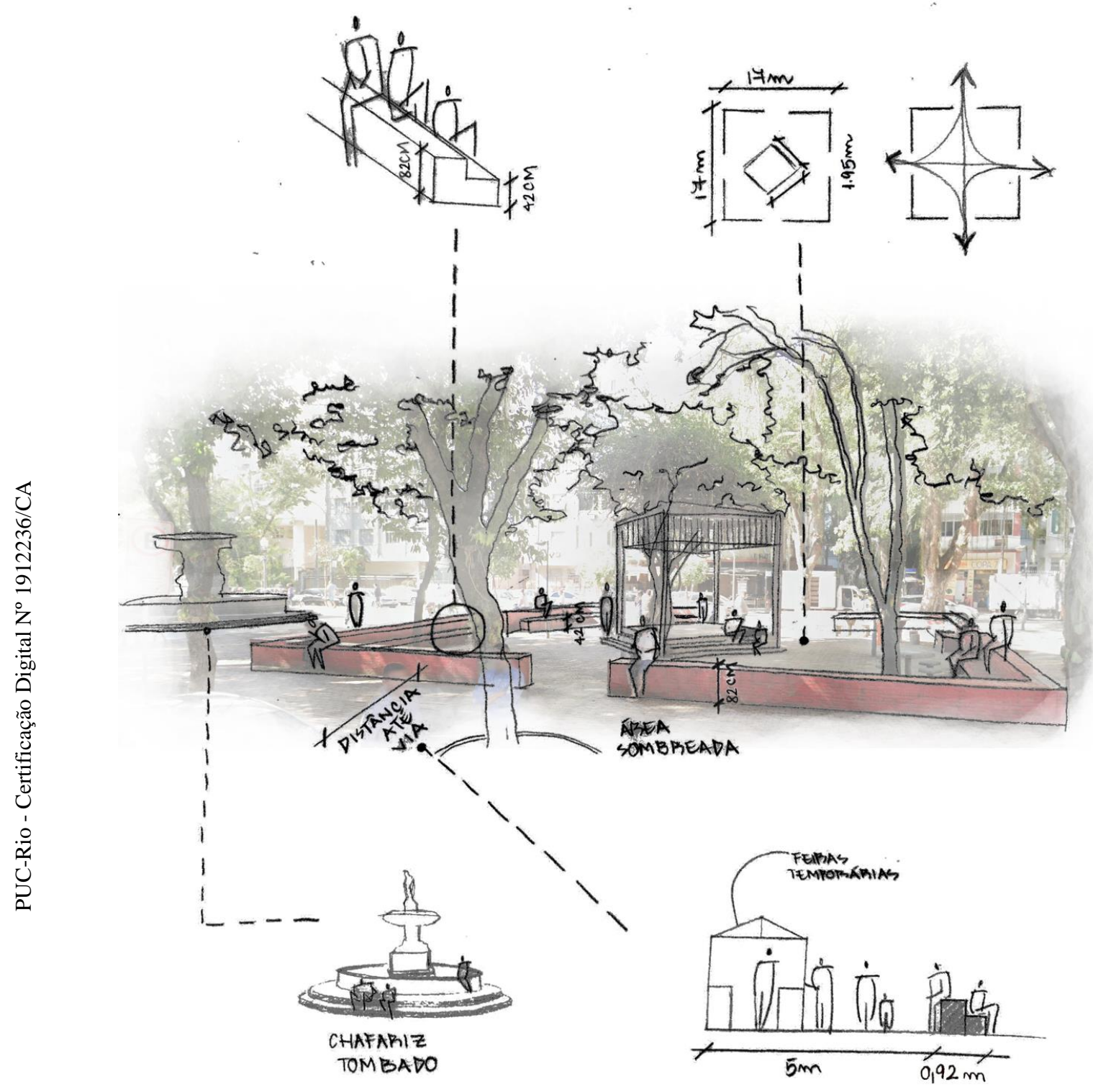

Figura 28: Croquis Praça São Salvador

Fonte: Elaborado pela autora 
Espacializar as memórias relativas à praça São Salvador coloca em questão os tempos desse lugar. A dinâmica local gera diferentes frequências figuradas por meio dos croquis a seguir. A figura 29 remete a praça em um dia de semana, no período da tarde, frequentada principalmente por moradores das imediações. Já a figura 30 busca remeter a praça em um dia de evento musical, onde se realizam também as feiras ao redor, em um domingo pela manhã, com frequentadores de outros bairros também. Diferentes experiências se realizam quando contrapomos dois tempos diversos. E, por isso, a própria sensação de acolhimento é também impactada pelo tempo do lugar.

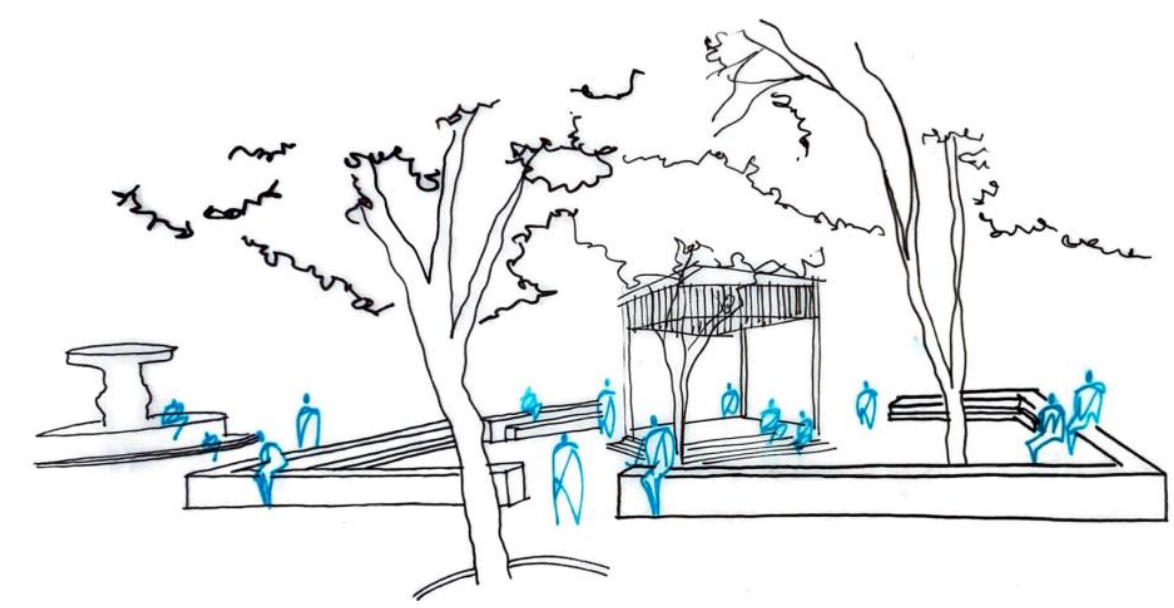

Figura 29: Croqui da Praça São Salvador em dia de semana, pela tarde Fonte: Elaborado pela autora

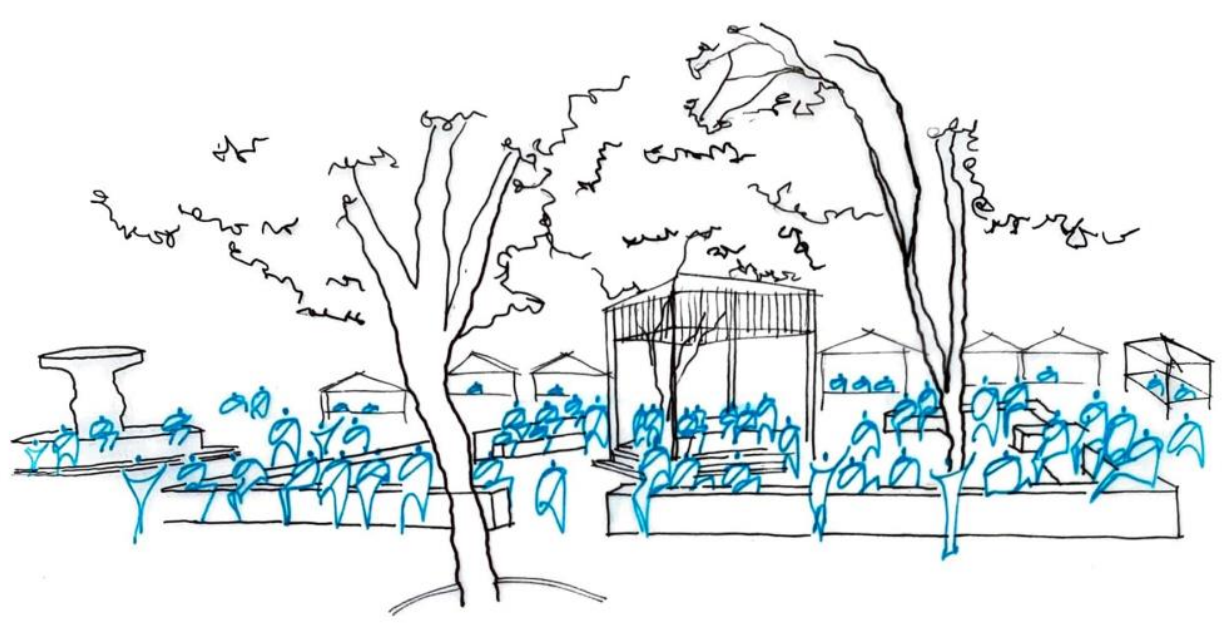

Figura 30: Croqui da Praça São Salvador em domingo com evento, pela manhã Fonte: Elaborado pela autora 


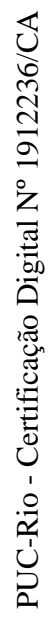
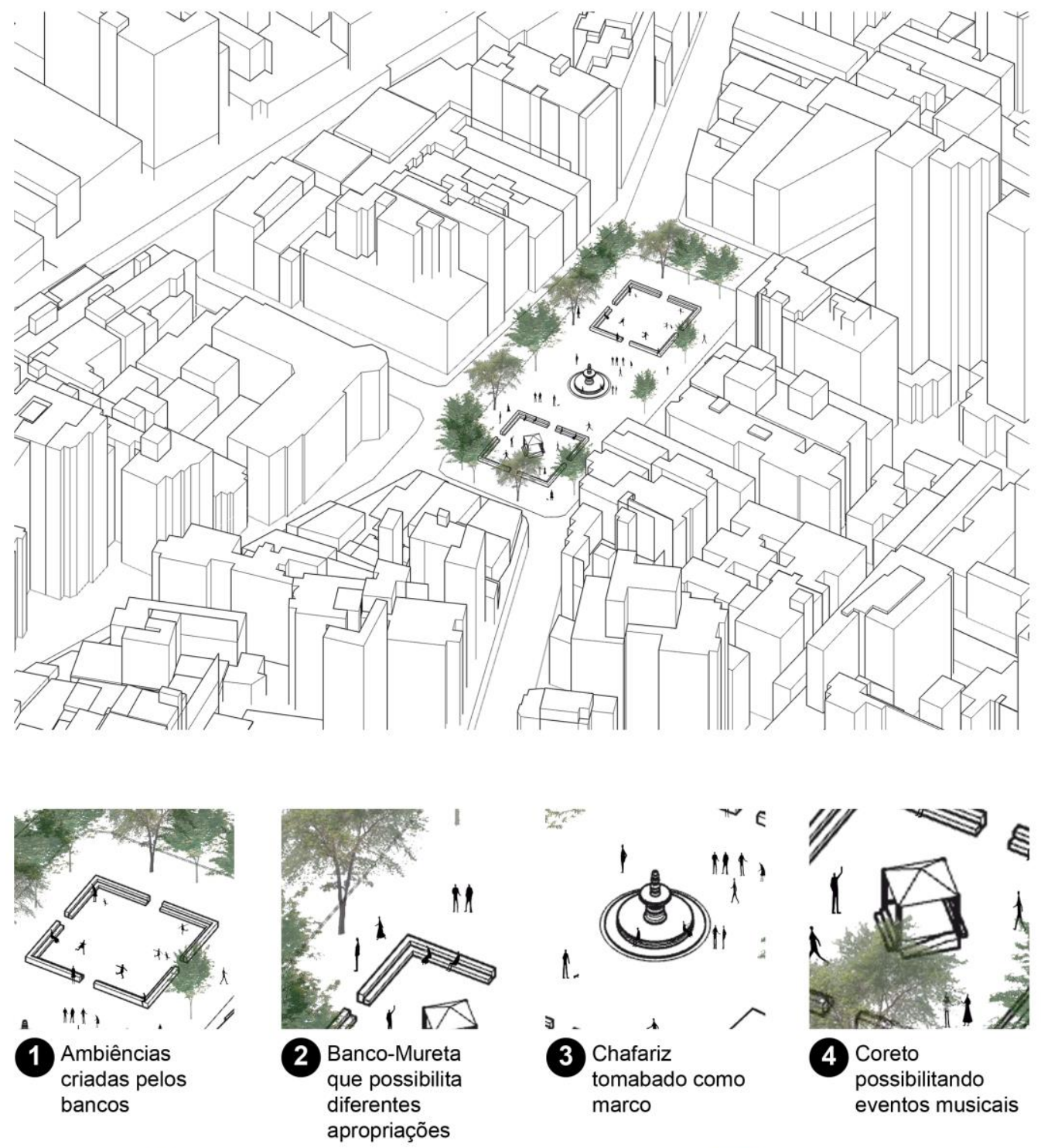
(3) Chafariz
tomabado como marco

(4) Coreto
possibilitando eventos musicais
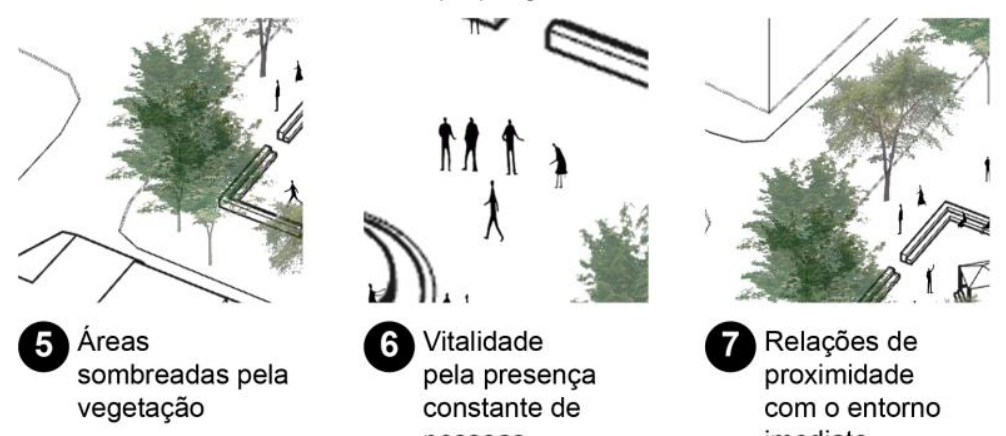
6 Vitalidade pela presença constante de pessoas
(7) Relações de proximidade com o entorno imediato

Figura 31: 3D Praça São Salvador com destaque para as dimensões da hospitalidade Fonte: Elaborado pela autora 
A figura 31 destaca dimensões da hospitalidade na praça São Salvador. Algumas dimensões são mais materiais e outras mais intangíveis. Todas elas, no entanto, se manifestam na experiência do habitante configurando acolhimento. Primeiramente a forma dos bancos da praça geram um espaço interior e outro exterior, delimitando ambiências. A transição entre eles se dá por meio das quatro aberturas que seccionam a volumetria dos bancos. Esses vazios são expressão da hospitalidade, pois convidam o habitante a entrar e recolher-se em seu interior. As aberturas no centro da aresta do quadrado de 17 metros geram cantos, acompanhados pelas mesinhas de praça, que reforçam também a sensação de acolhimento. A própria geometria da praça, neste caso, dispõe de um gesto de recolhimento que remete à hospitalidade. Pode-se estabelecer um paralelo entre os cantos formados e a enseada. Fuão destaca a concavidade da enseada como expressão do acolhimento da natureza ${ }^{198}$. Essa forma resguardada em relação ao seu contexto possui uma relação íntima com o banco da Praça São Salvador (Figura 32) que se volta para dentro, em direção ao parque infantil e coreto. Os cantos gerados acolhem, por exemplo, os pais que acompanham seus filhos na praça e o público que assiste as apresentações musicais no coreto.

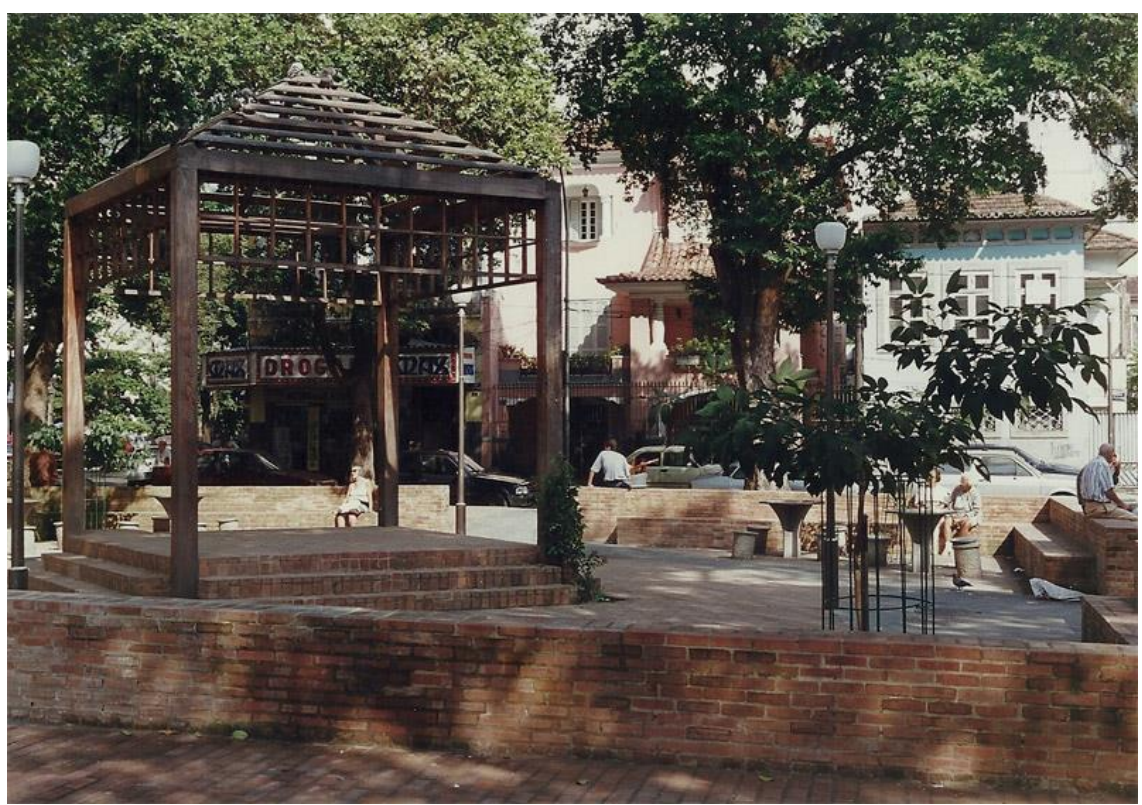

Figura 32: Bancos Praça São Salvador

Fonte: http://www.jauregui.arq.br/praca-sao-salvador.html

${ }^{198}$ FUÃO, 2015, p.101. 
O banco ou, como podemos chamar aqui, a casa sem telhado ou portas ${ }^{199}$ mostra sua flexibilidade na Praça São Salvador por meio das duas alturas, de $42 \mathrm{~cm}$ e $82 \mathrm{~cm}$ (Figura 33), que possibilitam diferentes apropriações do espaço, transformando-o em lugar a cada vivência e a cada contexto. Outros dois elementos identificados foram o coreto e o chafariz. Primeiramente eles são um marco na paisagem. Elementos marcantes, de acordo com Lynch, são pontos de referência que "funcionam como indicações absolutamente seguras do caminho a seguir"200. Apesar de serem marcos verticais localizados nas centralidades da praça, tanto o coreto como o chafariz tombado são apropriados em suas bases por possuírem formas adequadas ao corpo humano.

Outro elemento extremamente importante em uma vivência do acolhimento, principalmente na cidade do Rio de Janeiro, é a presença de vegetação. Primeiro, porque integra o ambiente construído à natureza, promovendo bem-estar. Segundo, porque gera áreas sombreadas, assegurando conforto ambiental.

A praça São Salvador extrapola os limites do bairro e é habitada por moradores de outros bairros graças a diversidade de eventos que ela abriga. Por isso é um espaço público muito utilizado, que conta constantemente com a presença de pessoas. Essa presença constante atribui a esse espaço elevada vitalidade. A vitalidade é, sem dúvida, fator importante na construção de um lugar hospitaleiro.

Por fim, a dimensão das calçadas e vias são também determinantes pois são definidoras das relações de proximidade entre a praça e o entorno. A proximidade com o comércio local cria um sistema de relações integradas que acolhe melhor o ser humano do que ambientes com atividades isoladas.

Mais do que identificar as dimensões que operam na realização da hospitalidade na arquitetura, é necessário se aproximar delas identificando suas medidas, que estruturam a experiência corporificada do espaço.

${ }^{199}$ BECKER apud FUÃO 2015, p. 77.

${ }^{200}$ LYNCH, 2011, p.90. 


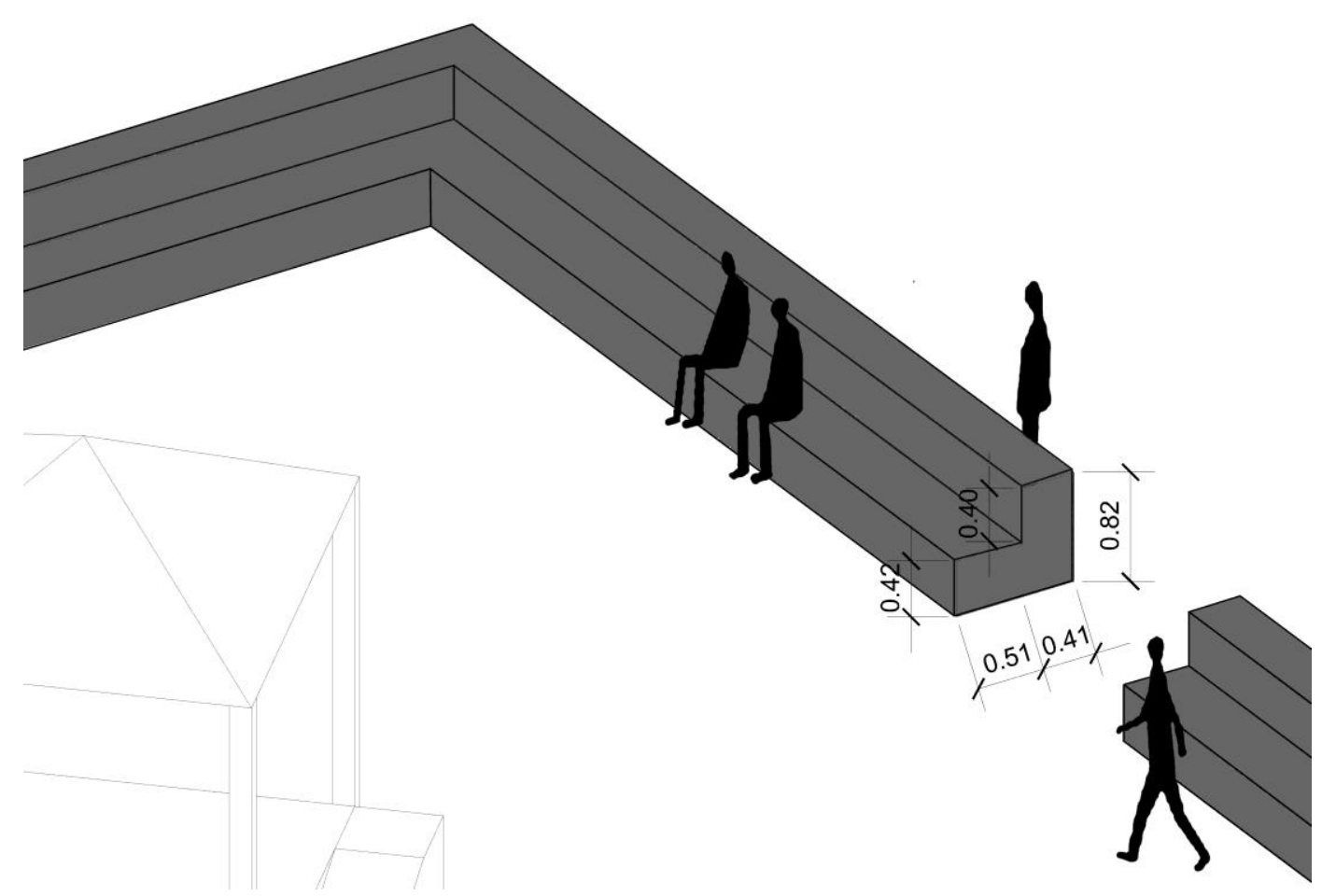

Figura 33: Dimensões banco Praça São Salvador Fonte: Elaborado pela autora

Observa-se que as escalas da hospitalidade operam de modo integrado, sendo impossível enxergá-las de modo dissociado (Figura 34). Um mesmo elemento pode operar em diferentes escalas e quando reunidos garantem a realização de um lugar da hospitalidade na cidade. Mais do que definir com qual escala cada fator supracitado se relaciona, busca-se aqui a compreensão de que estes elementos operam de modo conjunto. 


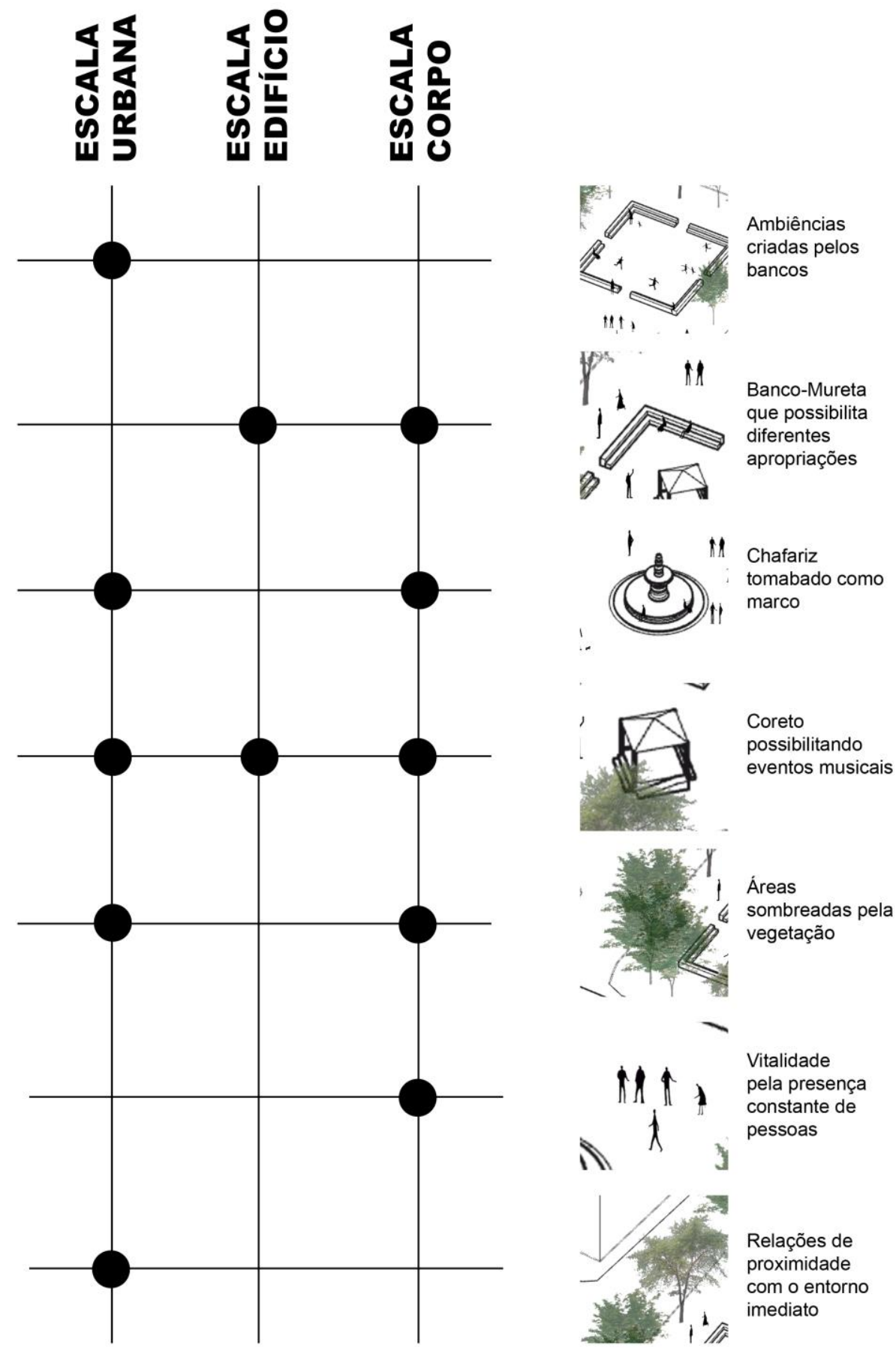

Figura 34: Elementos da hospitalidade na Praça São Salvador e suas respectivas escalas Fonte: Elaborado pela autora 
Diversas relações se estabelecem entre os habitantes e o espaço da praça. Essas relações definem elos afetivos e criam memórias. A figura 35 procura reunir, em uma colagem, algumas memórias de vivências já visualizadas naquele lugar.

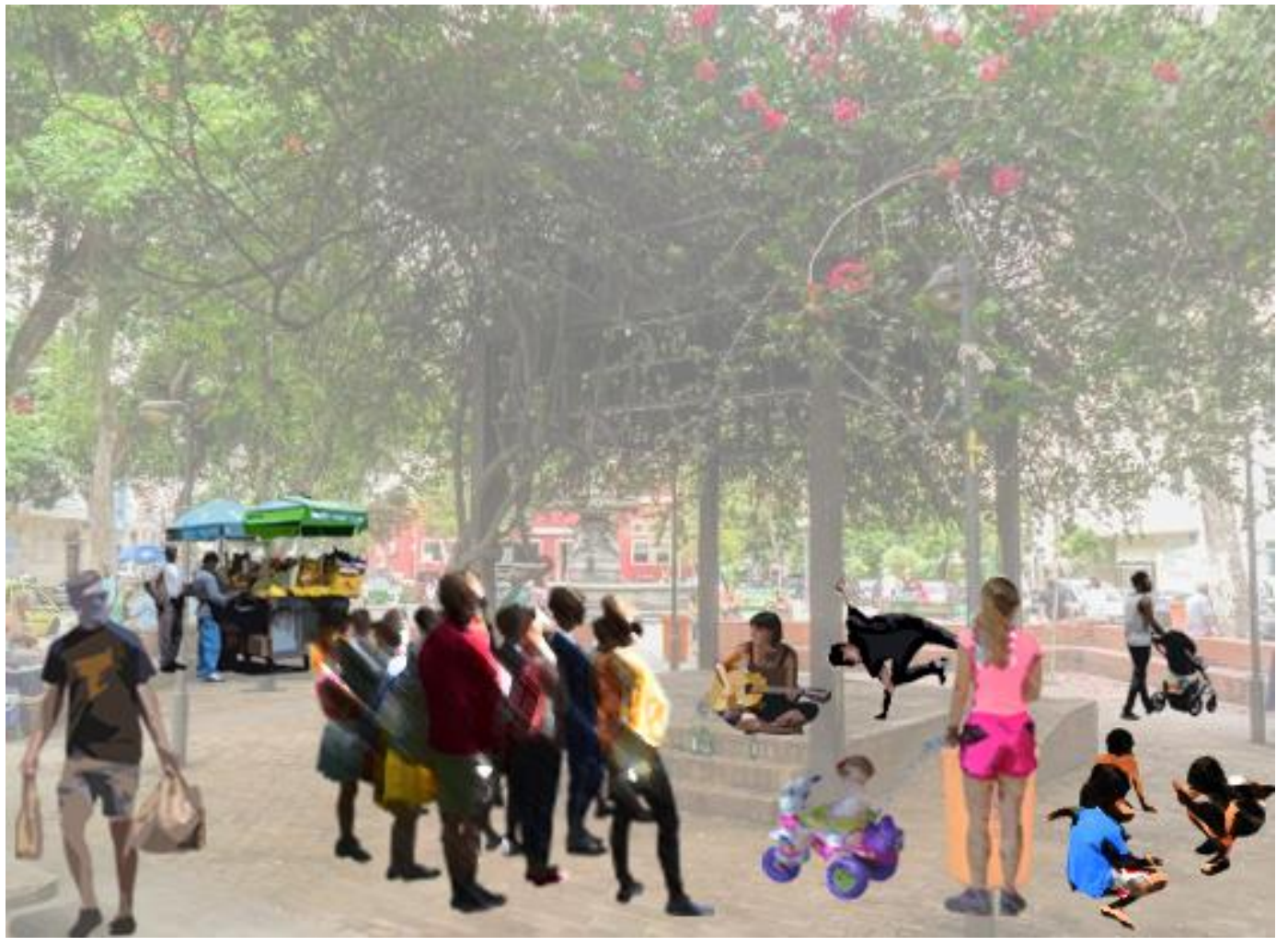

Figura 35: Colagem Praça São Salvador

Fonte: Elaborado pela autora 


\subsection{2.}

\section{Mureta da Urca - RJ}

A mureta da Urca, localizada no bairro da Urca (Figura 36), na cidade do Rio de Janeiro, é também potencial na investigação acerca do lugar da hospitalidade. A mureta de sustentação entre a baía de Guanabara e a calçada é ponto de encontro dos cariocas que podem apreciar a paisagem da enseada de botafogo e do Cristo Redentor, na proximidade dos bares do bairro.

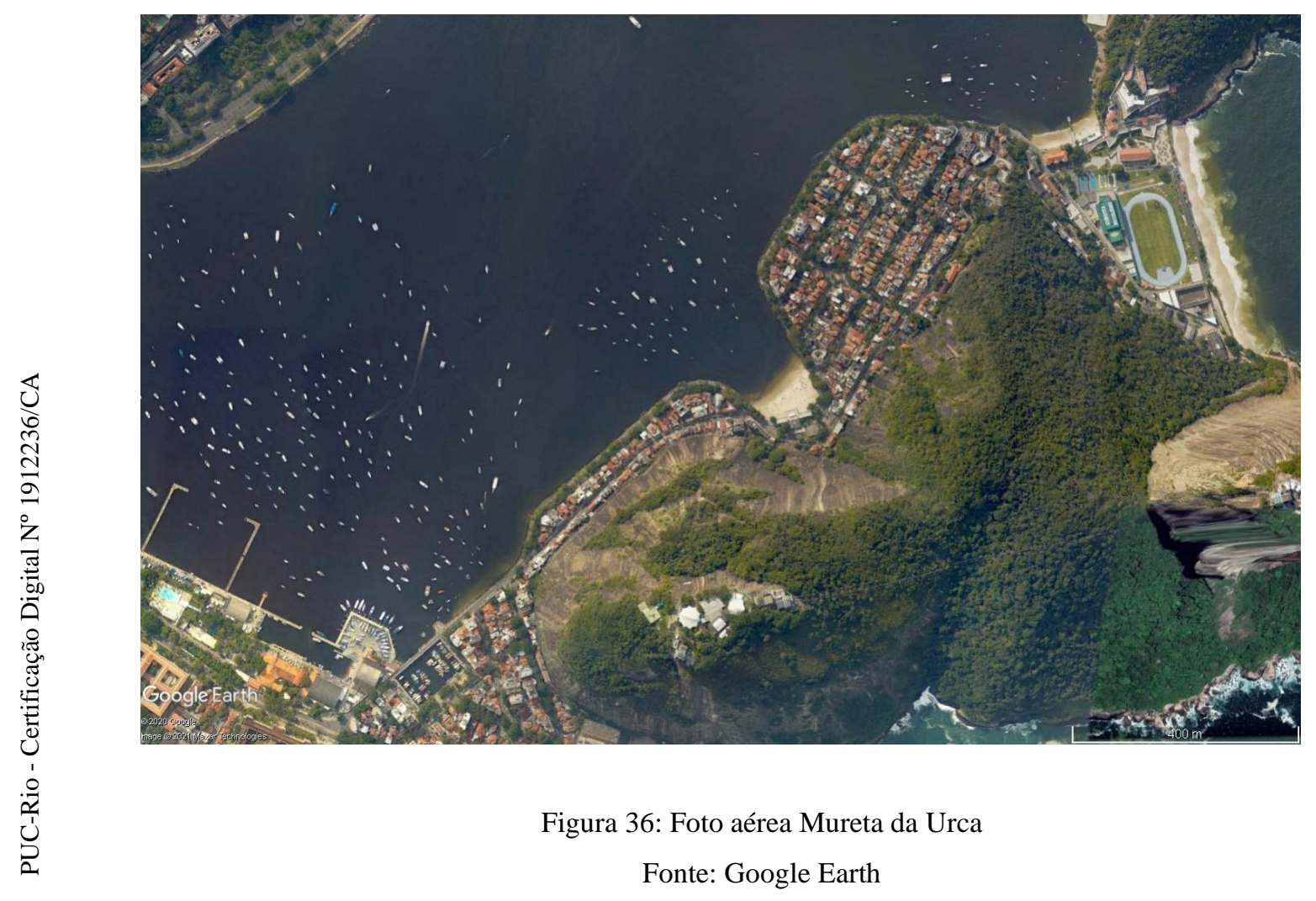

Este lugar da cidade do Rio de Janeiro é visitado diariamente. As pessoas habitam este espaço de diferentes maneiras, por meio de encontros, rodas musicais, churrascos, recolhimento para contemplação, dentre muitas outras. São variadas as vivências possíveis nesse lugar definido basicamente pela presença de uma mureta (Figura 37) junto a paisagem da enseada. 


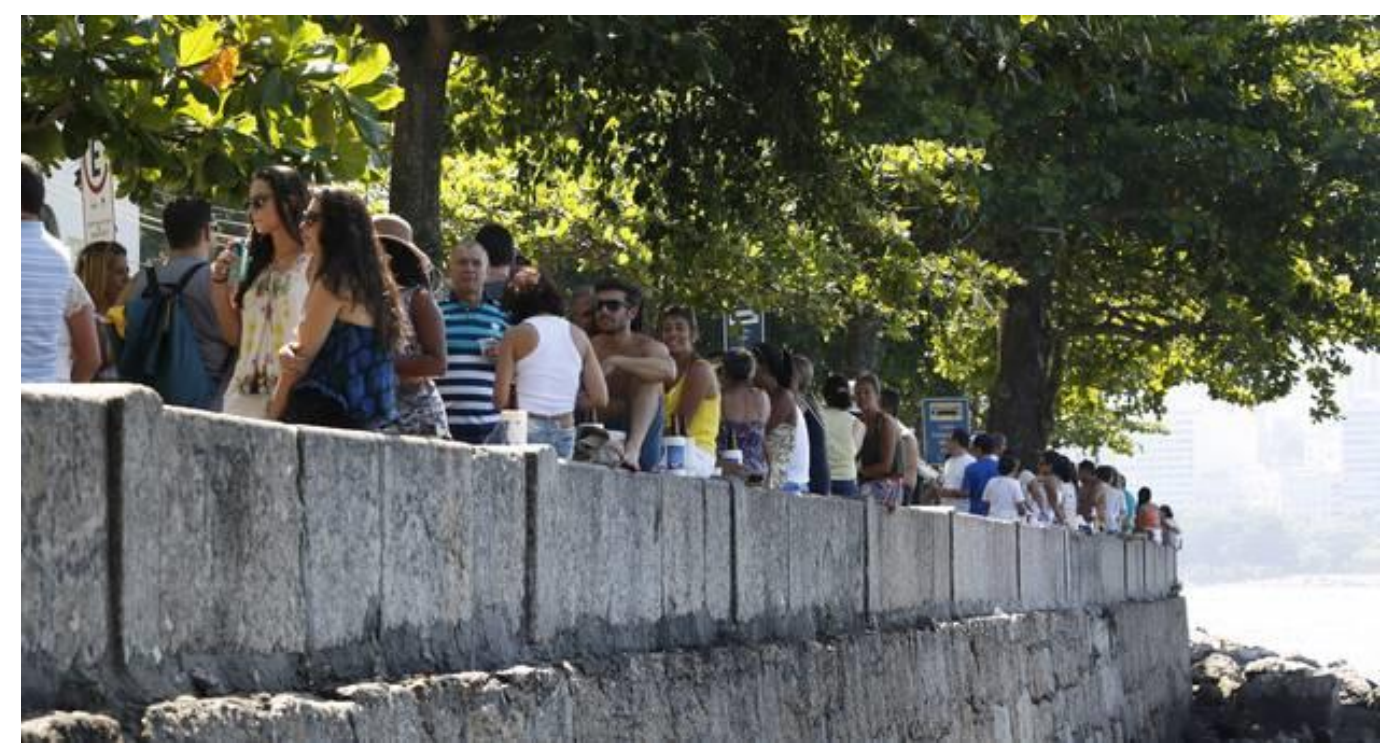

Figura 37: Mureta da Urca

Fonte: O Globo

A aparente simplicidade da mureta, a qual podemos relacionar novamente ao conceito de banco como casa sem telhados ou portas, não explica por si só a capacidade desse espaço de acolher e reunir tantas pessoas constantemente. O lugar, que já faz parte da identidade carioca, é configurado por um contexto propício que congrega paisagem, comércio local e mureta.

Fronteiras da hospitalidade apresentam uma característica comum: expandem-se, adquirindo ainda mais espessura. Uma fronteira hospitaleira tende a concentrar pessoas e por vezes, sua largura não dá conta do elevado nível de interações sociais. Por isso elas se expandem, apropriando-se dos espaços das ruas e integrando-se ao comércio ao redor. Esse processo pode ser observado na mureta da Urca. Em períodos com maior concentração de pessoas, o espaço das calçadas, principalmente próximo aos bares, não é suficiente para abrigar o elevado número de pessoas que passam a ocupar também trechos das avenidas Portugal e João Luiz Alves.

A seguir, por meio de croquis (Figura 38), o lugar foi lido em busca dos fatores mais importantes para a construção de um lugar da hospitalidade. Essas dimensões serão exploradas novamente de modo individual a seguir. 


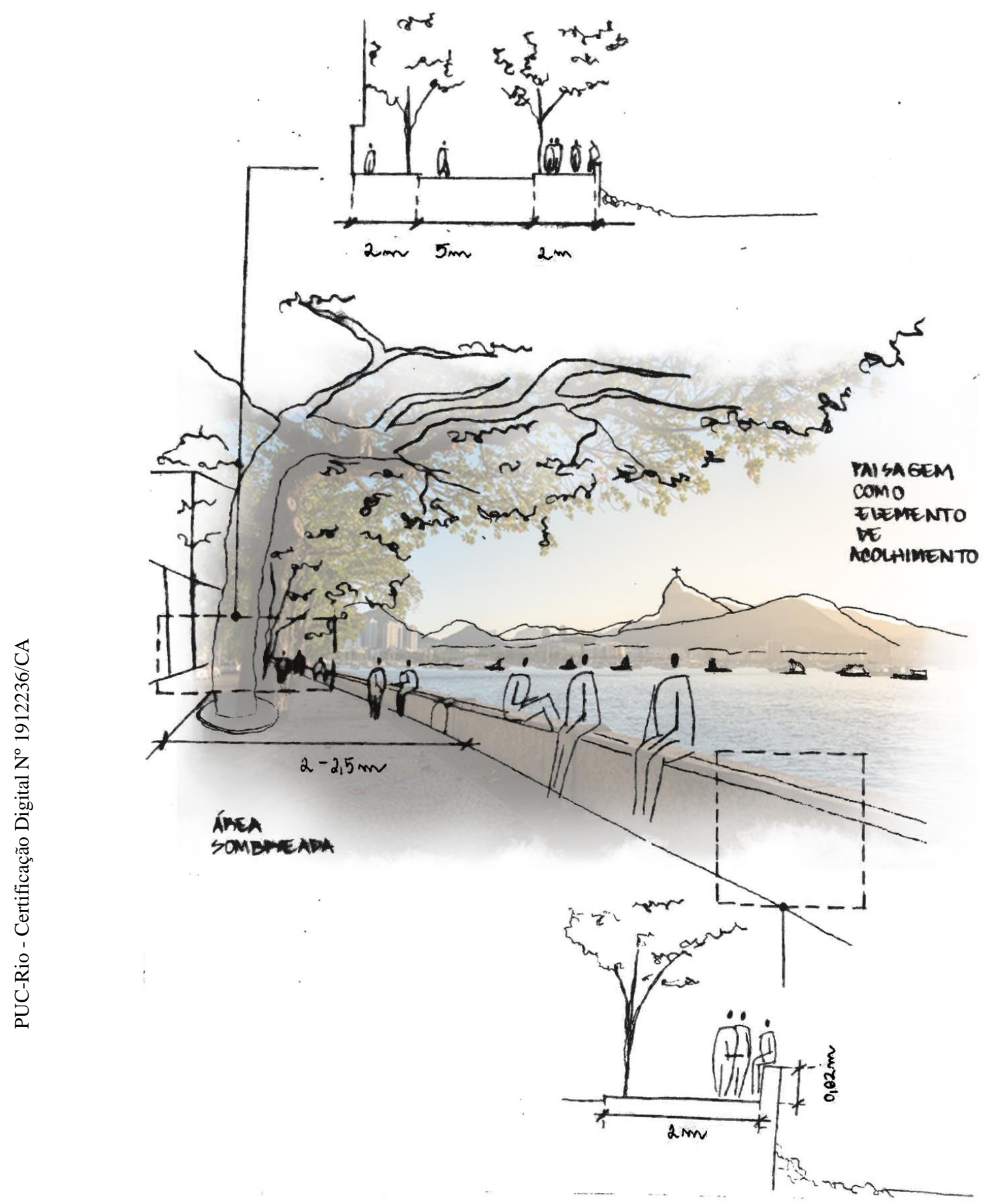

Figura 38: Croquis Mureta da Urca

Fonte: Elaborado pela autora 
Assim como a Praça São Salvador, a mureta da Urca também apresenta frequências diversas, não apenas de acordo com o tempo, mas ao longo do seu próprio comprimento. Os trechos mais próximos aos bares apresentam ritmos mais intensos em relação aos trechos mais afastados. De acordo com o período da semana, a concentração de pessoas varia. Abaixo, as figuras 39 e 40 buscam figurar e contrapor diferentes tempos da mureta.

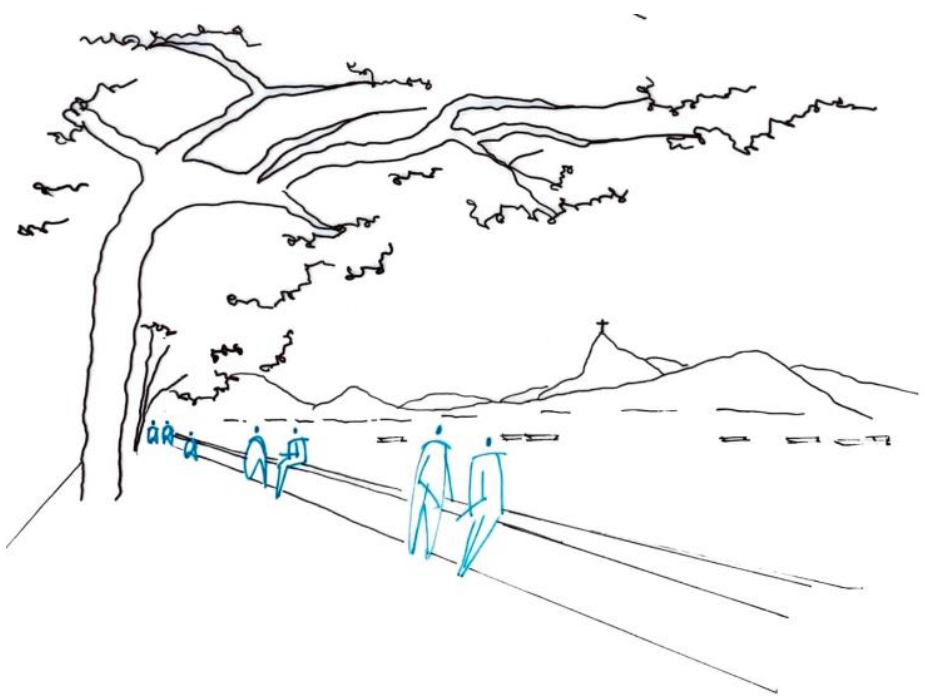

Figura 39: Croqui da Mureta quarta-feira, pela tarde Fonte: Elaborado pela autora

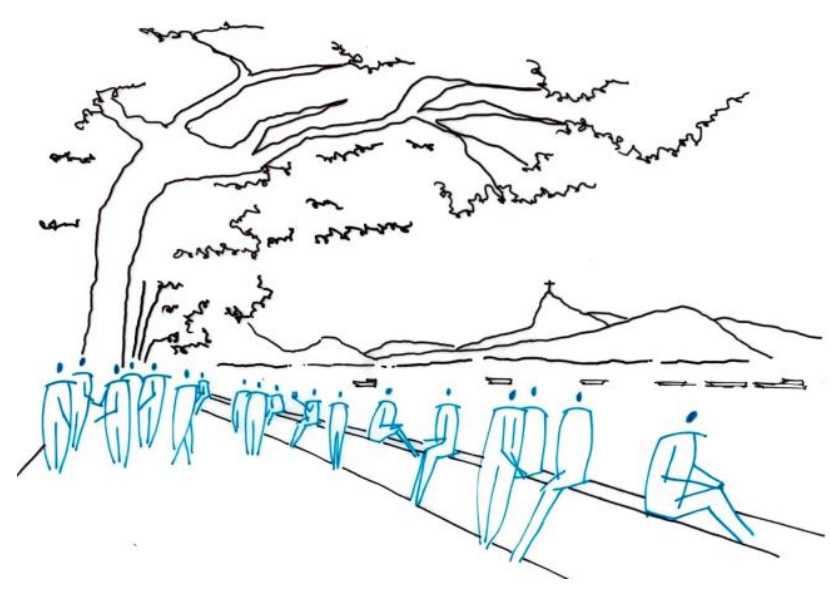

Figura 40: Croqui da Mureta sexta-feira, início da noite Fonte: Elaborado pela autora 


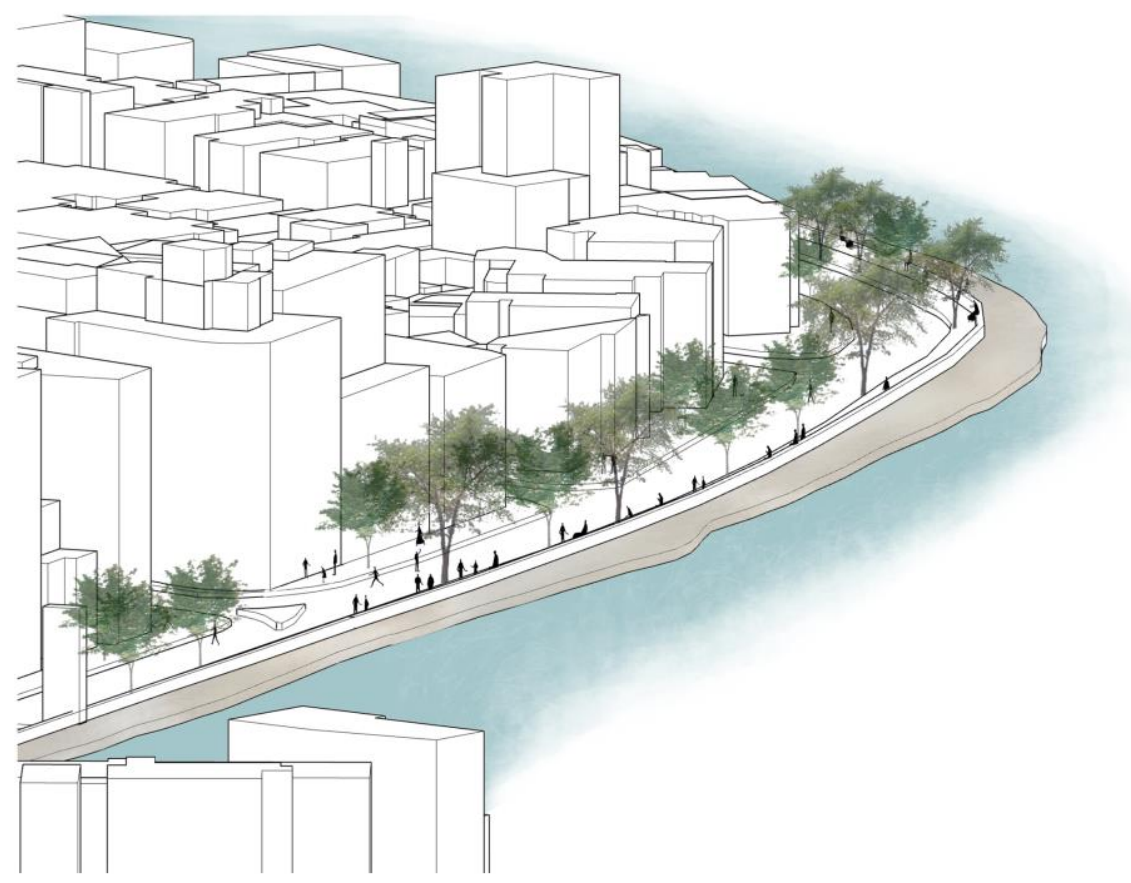

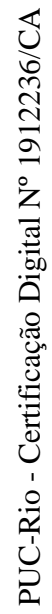
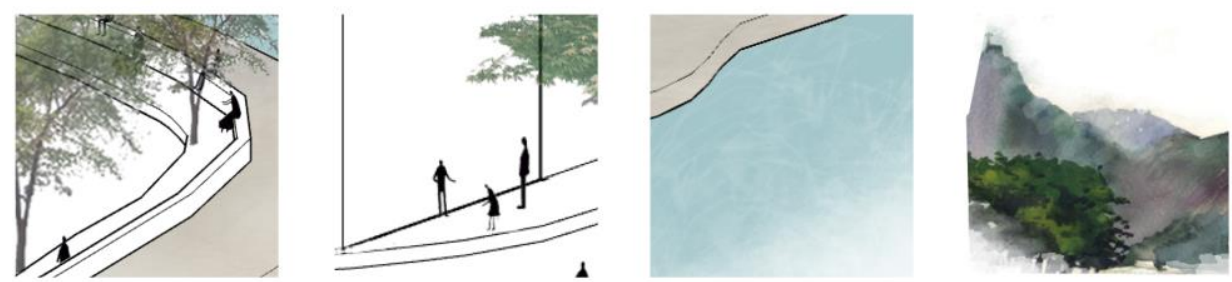

(1) Mureta que

posibilita

contemplação da paisagem

(2) Bares ao

redor criando frequencias ao longo da mureta

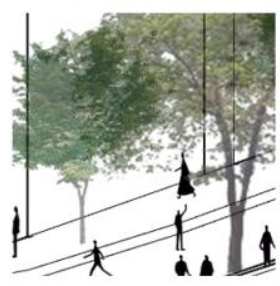

(5) Áreas

sombreadas pela vegetação

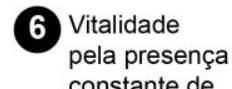

(3) Presença da água e pedras aproximando à natureza

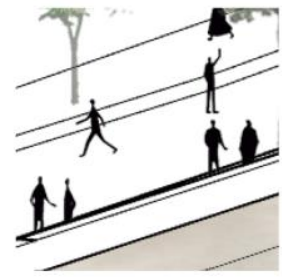
pessoas

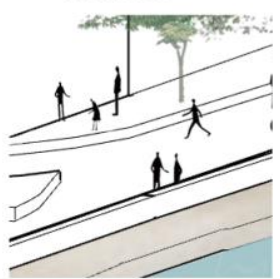

(7) Relações de proximidade com o entorno imediato

Figura 41: 3D Mureta da Urca com destaque para dimensões da hospitalidade Fonte: Elaborado pela autora 
A figura 41 apresenta e destaca algumas dimensões da hospitalidade no espaço da mureta. Vale ressaltar que esta análise não esgota, e nem pretende esgotar, a variedade de fatores que atuam no acolhimento. Objetiva-se aqui compreender como operam de modo conjunto e estabelecer paralelo com o estudo de caso anterior, visualizando semelhanças e diferenças. Dessa forma, será possível enxergar pontos de contato entre os lugares da hospitalidade no Rio de Janeiro.

O primeiro elemento destacado é a própria mureta, com $62 \mathrm{~cm}$ de altura e 35 $\mathrm{cm}$ de largura. Esta altura permite que o habitante encoste o corpo ou sente para contemplação da paisagem. Este elemento simples, em pedra, quando inserido naquele contexto atribui enorme valor ao espaço, transformando-o em um lugar que as pessoas habitam. Por meio da mureta as pessoas se sentem acolhidas e convidadas a permanecer. Um simples gesto de hospitalidade à beira da enseada.

Outro elemento relevante é a presença dos bares. Estes estabelecimentos criam centralidades ao longo desta fronteira, estabelecendo ritmos variados ao longo do limite com o mar. Os comerciantes locais compreenderam a mureta como um catalisador de encontros e por vezes vão até a calçada da mureta oferecer o serviço.

A presença da paisagem, da água e das pedras pode também ser lida aqui como uma das dimensões geradoras de acolhimento. A mureta não seria mesma sem a presença da paisagem ou proximidade em relação ao mar. O contexto físico cria um ambiente adequado para a contemplação.

Assim como na praça, todo o comprimento das avenidas Portugal e João Luiz Alves é marcado pela presença de árvores que garantem que a mureta esteja sombreada, promovendo maior conforto ambiental ao habitante à beira da enseada.

Estas dimensões reunidas conformam um lugar marcado pela presença constante de pessoas e a vitalidade, como já mencionado anteriormente, pode ser considerado fator importante na realização da hospitalidade na arquitetura.

Por fim, novamente as distâncias que se estabelecem com o entorno imediato são fundamentais para a definição de relações de proximidade. Os bares do entorno encontram-se a uma distância de cerca de 14 metros da mureta, o que permite que a fronteira se expanda naturalmente. 


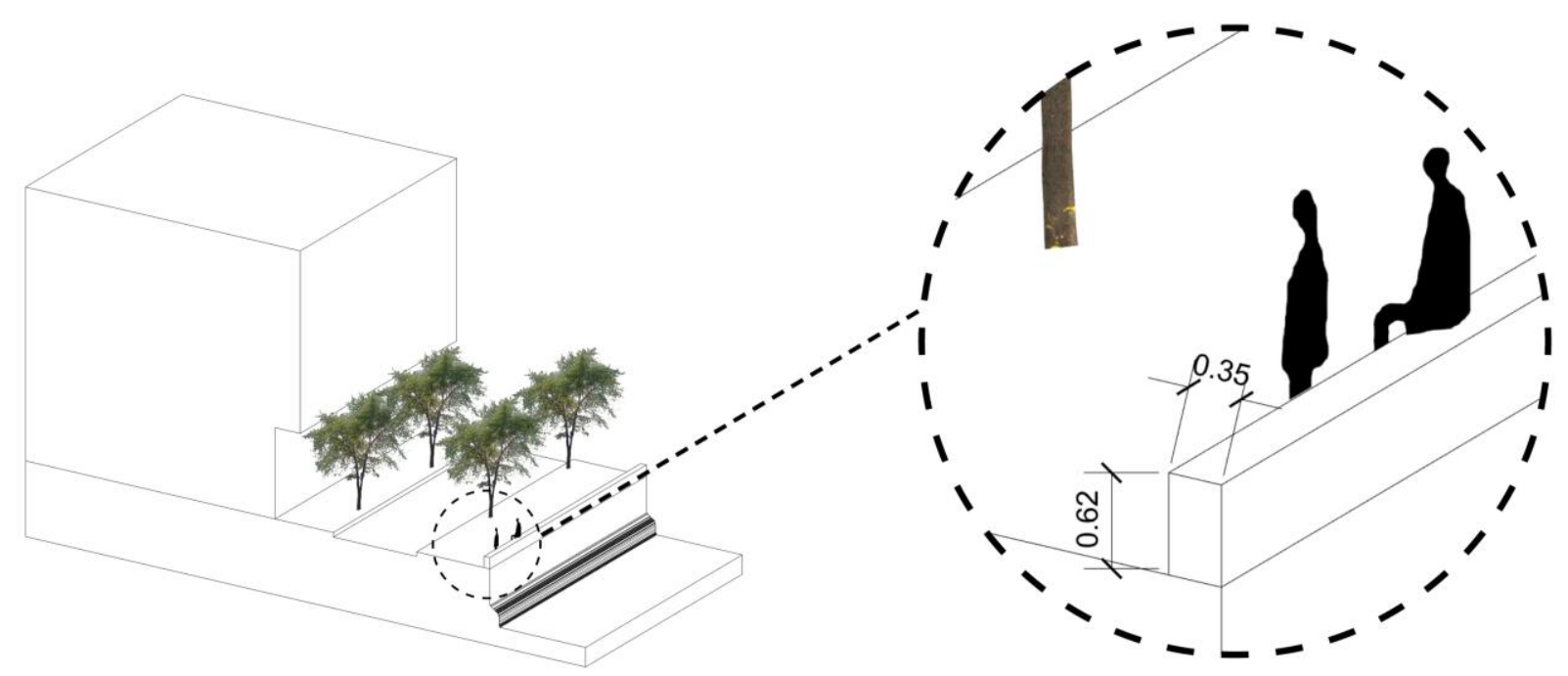

Figura 42: Dimensões Mureta da Urca

Fonte: Elaborado pela autora

A Figura 42 apresenta a mureta de modo aproximado, com suas dimensões precisas. A largura de $35 \mathrm{~cm}$ e a altura de $62 \mathrm{~cm}$ garantem uma experiência corporificada adequada às dimensões humanas. Esta mureta é apropriada de diferentes maneiras em função das dimensões que possui. Essa flexibilidade do espaço contempla diferentes usos desse lugar de contemplação na cidade do Rio de Janeiro. 
O diagrama a seguir (Figura 43) apresenta como os elementos operam de modo integrado em cada escala da hospitalidade, reafirmando que uma hospitalidade da arquitetura depende de uma ação integrada.
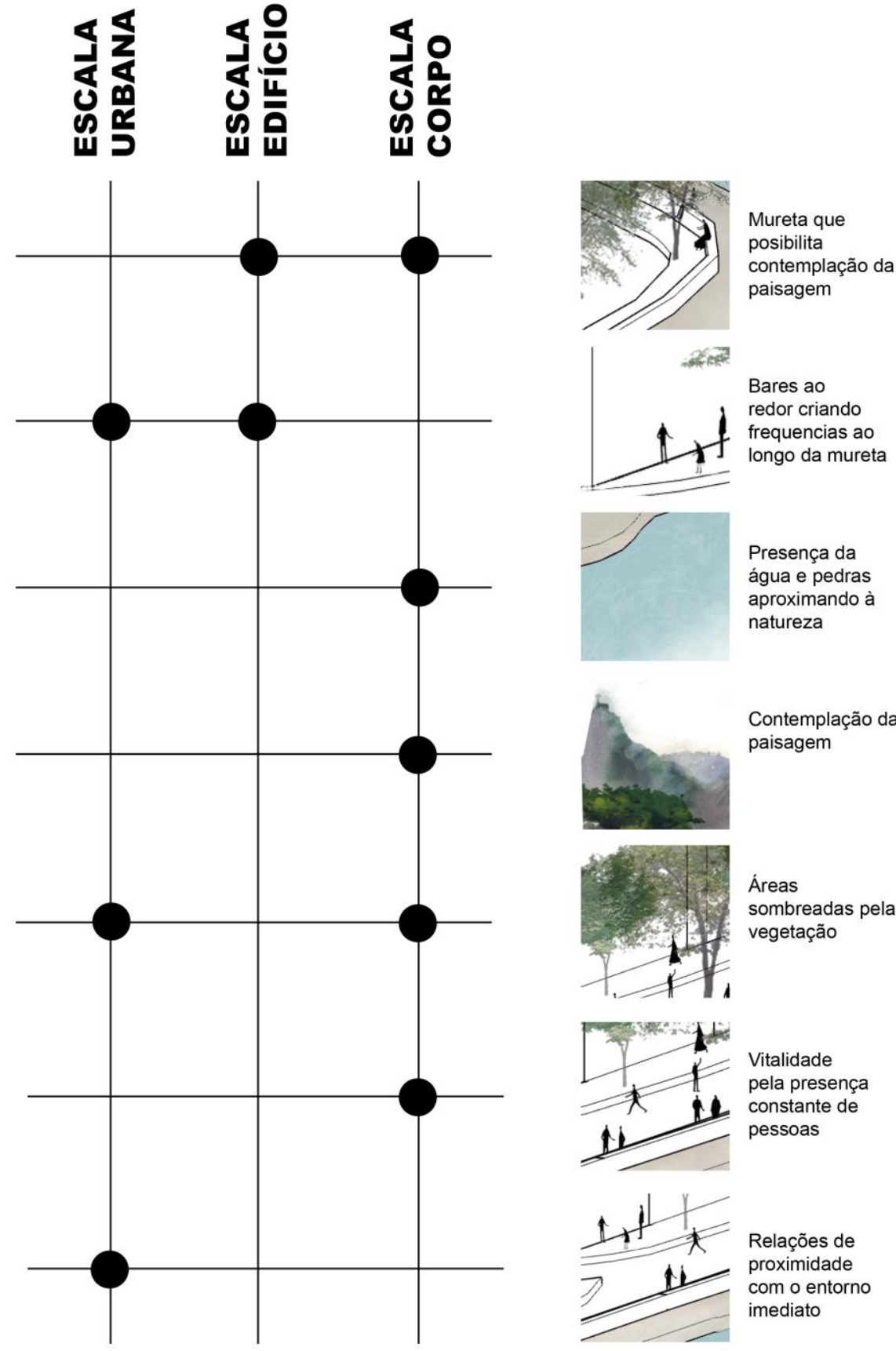

Figura 43: Elementos da hospitalidade na Mureta da Urca e suas respectivas escalas Fonte: Elaborado pela autora 
Um aspecto que merece destaque é geometria do acolhimento. Fuão destaca que a concavidade da enseada propicia a contemplação e o recolhimento. A natureza proporciona algumas conformações espaciais acolhedoras como a enseada, a caverna e a gruta. "A natureza é o acolhimento incondicional"201. A mureta da Urca (Figura 44), banhada pela Baía de Guanabara (Figura 45), já se encontra de alguma forma inserida em uma geometria do acolhimento da própria natureza.

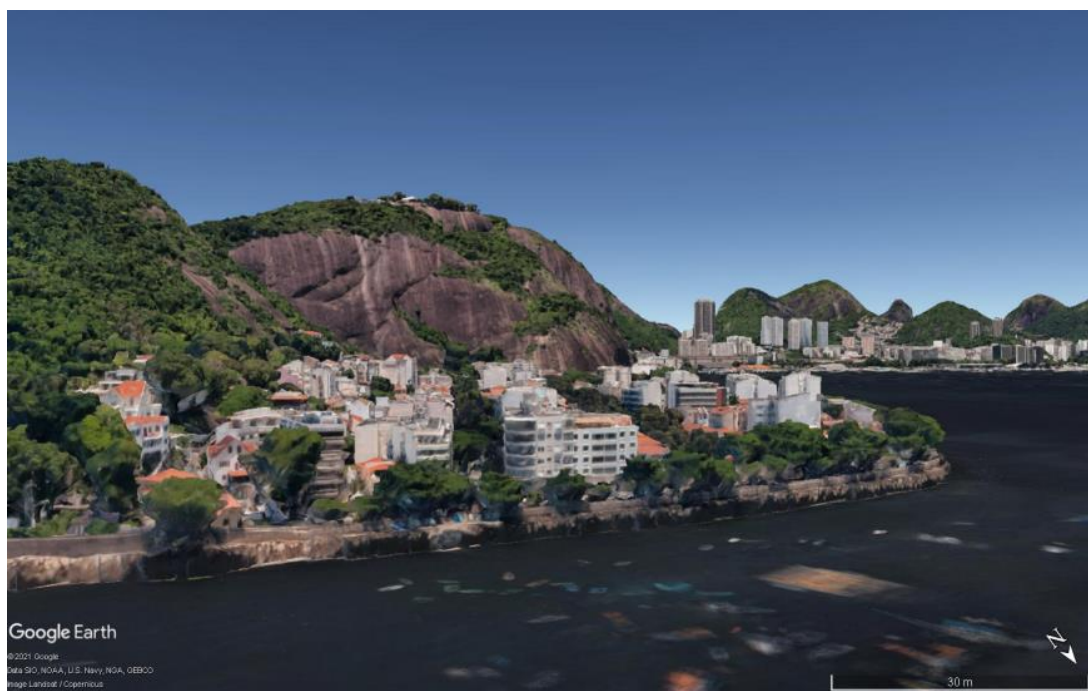

Figura 44: 3D fotorrealista da Mureta da Urca Fonte: Google Earth

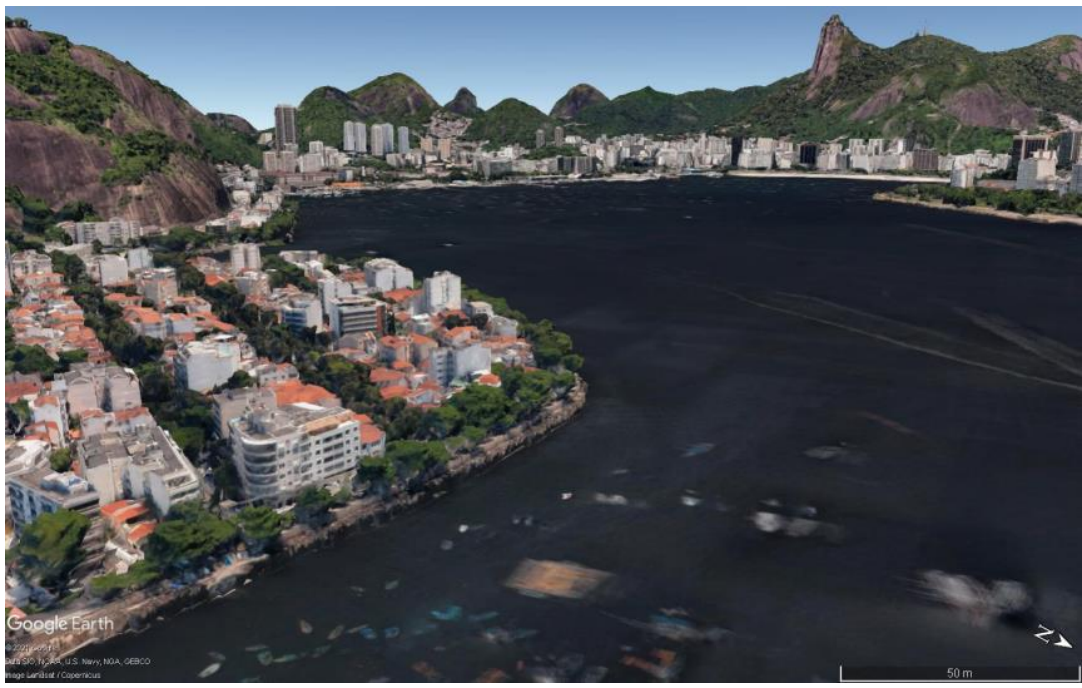

Figura 45: 3D fotorrealista da enseada

Fonte: Google Earth

${ }^{201}$ FUÃO, F. As formas do acolhimento na arquitetura. In SOLIS, Dirce Eleonora Nigro; FUÃO, Fernando Freitas. Derrida e arquitetura. Rio de Janeiro: EdUERJ, 2015, p.101 
São variadas as possibilidades de habitar a mureta. Procurou-se novamente reunir em uma colagem as memórias das vivências presenciadas nesse lugar (Figura 46). A diversidade que a imagem revela aponta para o acolhimento desse espaço que reúne diferentes pessoas constantemente.

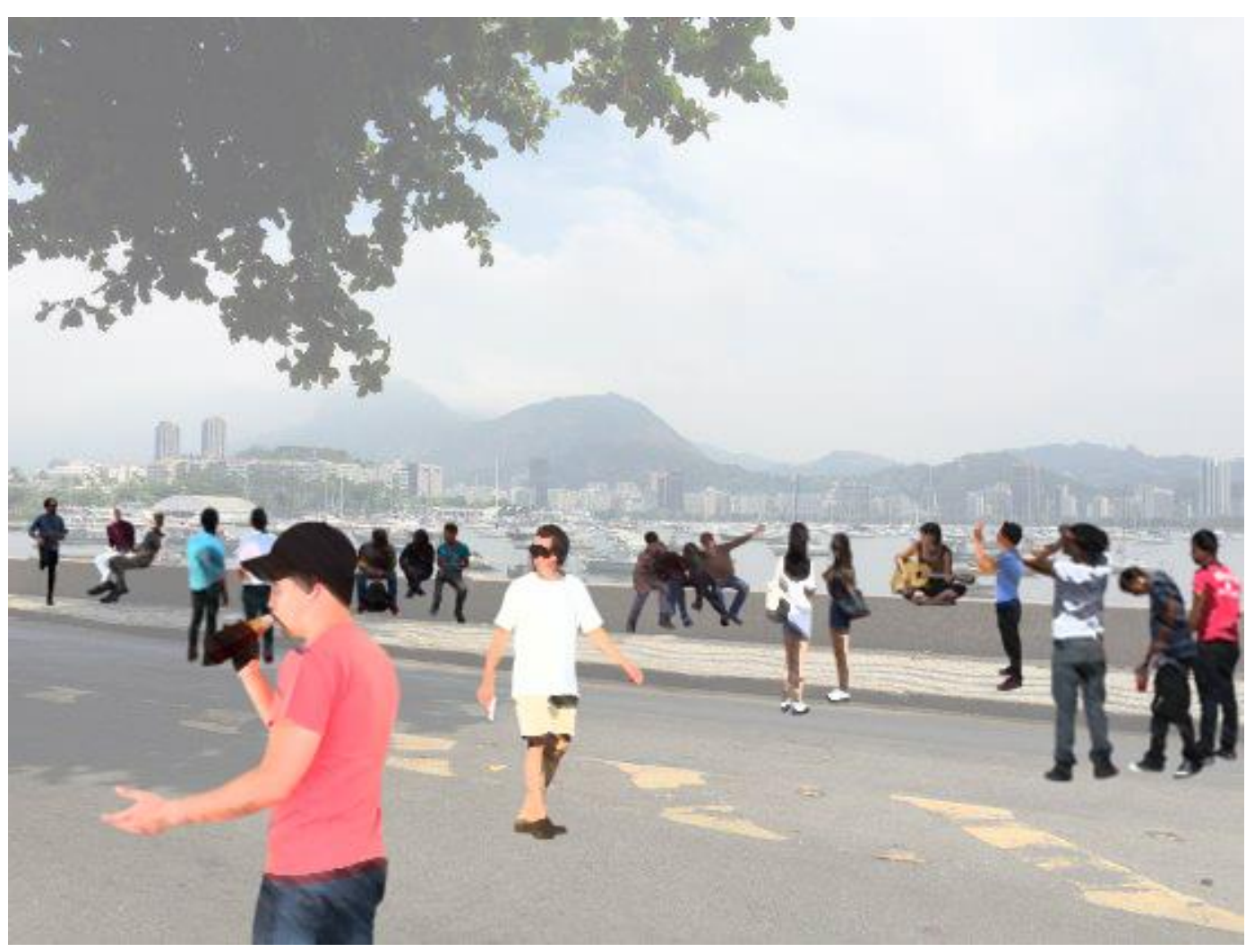

Figura 46: Colagem Mureta da Urca

Fonte: Elaborado pela autora 


\section{3.}

\section{Matriz de análise da hospitalidade}

Uma observação do espaço habitado ao longo do tempo é premissa para a análise da hospitalidade. Avaliar um ambiente por meio de um recorte muito restrito no espaço-tempo limita consideravelmente a compreensão do acolhimento neste lugar. É necessário, portanto, ampliar o período de observação, pois a hospitalidade do lugar não é uma característica imóvel e constante. Ela depende de múltiplas dimensões operando em conjunto. A hospitalidade tem a ver com o que o lugar oferece, aspecto que oscila ao longo do dia, semana e meses. Por isso, incorporar o fator tempo nesta leitura foi necessário.

Algumas informações sobre o gesto de acolher por meio do projeto estão latentes nos espaços do cotidiano e, portanto, apenas visualizá-las não é suficiente para trazê-las à tona. Desenhar e redesenhar estes espaços é a ferramenta proposta para revelá-las. Por meio do croqui é possível observar o espaço, e também sentilo. Os diagramas sintetizam relações identificadas na investigação, comunicando, de modo simplificado, as dimensões do acolhimento de cada espaço. A colagem, por sua vez, auxilia a narrar uma história. Por meio dela se expressam memórias relativas as vivências coletivas do lugar investigado. A memória é mobilizada como instrumento de análise que não se restringe a documentar formas de apropriação. Objetiva primordialmente trazer a tona relações de afeto em relação ao espaço.

É possível afirmar que a memória não é apenas uma série de memórias imóveis, que podem ser capturadas ou localizadas no tempo como numa análise bastante biográfica do espaço e de seus eventos [...] mas que se trata de uma compreensão hermenêutica desse presente, desde a qual se acessa uma intimidade conformadora da memória da qual o próprio arquiteto faz parte. ${ }^{202}$

O processo de pesquisa e de análise dos estudos de caso teve como resultado a construção de uma matriz de análise da hospitalidade. Essa matriz foi se consolidando gradualmente durante o processo de pesquisa. O objetivo seria pontuar, para cada dimensão, quais são as ferramentas de análise utilizadas. Algumas ferramentas se revelam mais adequadas a dada dimensão da hospitalidade, tendo em vista que estas operam em diferentes esferas. A matriz é, portanto, um

${ }^{202}$ ESPÓSITO, 2011, p.92 (tradução da autora). 
resultado do processo investigativo da presente pesquisa, que pode servir como ponto de partida para análise, sob a ótica da hospitalidade, de outros espaços. A reflexão acerca do acolhimento e o ferramental que oferece suporte para isso, no entanto, não se esgota por meio dela e admite ser complementação. Cada espaço investigado pode surpreender com uma nova camada de leitura do acolhimento espacial.

A matriz proposta pode servir de guia para estruturar futuras análises das arquiteturas da hospitalidade, abarcando o acolhimento em suas dimensões mentais e físicas. Esta seria mais uma das contribuições da pesquisa: guiar uma investigação em torno do lugar da hospitalidade. Observa-se que ela pode ser aplicada em espaços de naturezas distintas. Desde espaços triviais cotidianos até obras emblemáticas. Por meio dela não se realiza uma análise de projeto em seus diversos campos, mas uma análise concentrada nas dimensões do acolhimento em arquitetura.

A matriz (Figura 47) possui em seu eixo horizontal as principais dimensões da hospitalidade identificadas pela pesquisa, que atuam em âmbito mental e corporificado. $\mathrm{O}$ eixo vertical apresenta as ferramentas mobilizadas para a análise do acolhimento do espaço. As células de cruzamento entre elas apresentam quais ferramentas podem ser utilizadas para a leitura de cada dimensão e uma orientação para cada etapa da análise que compõe esta investigação. A matriz sintetiza o processo de análise decorrente de uma investigação teórica que elencou previamente os aspectos primordiais do acolhimento do espaço. 
DIMENSÕES DA HOSPITALIDADE

\begin{tabular}{|c|c|c|c|c|c|c|}
\hline & $\begin{array}{c}\text { MATRIZ DE } \\
\text { ANÁLISE DA } \\
\text { HOSPITALIDADE }\end{array}$ & $\begin{array}{l}\text { Contexto físico, } \\
\text { histório e social }\end{array}$ & $\begin{array}{l}\text { Nivel de abertura do } \\
\text { espaço analisado }\end{array}$ & $\begin{array}{c}\text { Presença de } \\
\text { elementos que } \\
\text { contribuem para a } \\
\text { habitabilidade }\end{array}$ & $\begin{array}{c}\text { Zonas e/ou } \\
\text { temporalidades da } \\
\text { intensidade do uso } \\
\text { social }\end{array}$ & $\begin{array}{c}\text { Memórias espaciais } \\
\text { relativas ao afeto em } \\
\text { relaçẫo ao lugar }\end{array}$ \\
\hline \multirow{2}{*}{\multicolumn{2}{|c|}{ 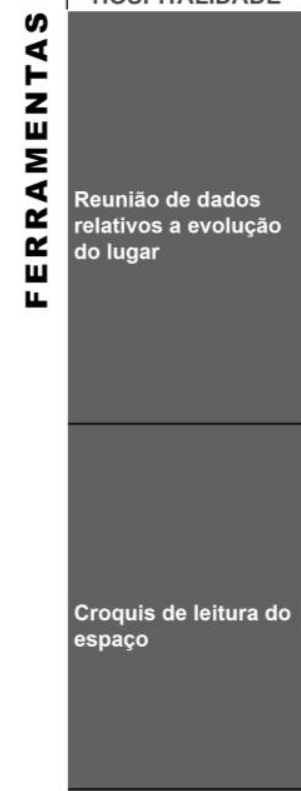 }} & $\begin{array}{l}\text { Compreensão das } \\
\text { dimensões fisica, } \\
\text { histórica, social, política } \\
\text { e cultural por meio de } \\
\text { um levantamento das } \\
\text { práticas sociais locais, } \\
\text { identificando dinâmicas } \\
\text { dos espaços, anteriores } \\
\text { e atuais. Além disso, } \\
\text { uma compreensão do } \\
\text { contexto geográfico } \\
\text { é fundamental para } \\
\text { identificar variáveis } \\
\text { climáticas que } \\
\text { impactam diretamente a } \\
\text { sensação de conforto e } \\
\text { acolhimento. } \\
\end{array}$ & \begin{tabular}{|l|} 
Reunião de \\
informações acerca do \\
desenvolvimento da \\
fronteira. \\
Indentificação dos ciclos \\
de intervenções que \\
conformaram este lugar, \\
definindo o caráter dos \\
limites espaciais.
\end{tabular} & $\begin{array}{l}\text { Observação de quais } \\
\text { elementos estão } \\
\text { presentes no lugar } \\
\text { analisado, buscando } \\
\text { identificar a forma como } \\
\text { as pessoas se apropriam } \\
\text { deles. }\end{array}$ & $\begin{array}{l}\text { Observação e registro } \\
\text { dos dados acerca da } \\
\text { variação da intensidade } \\
\text { de utilização do espaço. } \\
\text { Quais ambientes } \\
\text { concentram maior } \\
\text { número de pessoas } \\
\text { e por que? Em que } \\
\text { periodos do dia, da } \\
\text { semana ou do mês o } \\
\text { lugar analisado é mais } \\
\text { utilizado? Essas zonas } \\
\text { especificas e periodos } \\
\text { especificos demarcam } \\
\text { uma expansão das } \\
\text { fronteiras do espaço? }\end{array}$ & $\begin{array}{l}\text { Registro das } \\
\text { recordações acerca do } \\
\text { lugar em análise e/ou } \\
\text { busca pelas recordações } \\
\text { de outras pessoas em } \\
\text { relação a este lugar. }\end{array}$ \\
\hline & & & \begin{tabular}{|l|} 
Croquis para análise \\
da fluidez em zonas \\
de alternância entre \\
diferentes espaços por \\
meio da abertura das \\
fronteiras entre espaços. \\
Por meio desses croquis \\
será possivel observar \\
a possibilidade de se \\
habitar essas fronteiras, \\
de modo que elas não \\
atuem no espaço como \\
barreiras, mas como \\
costura.
\end{tabular} & $\begin{array}{l}\text { Croquis como ferramenta } \\
\text { de imaginação das } \\
\text { possiveis formas de } \\
\text { habitar o espaço. } \\
\text { Identificação dos } \\
\text { elementos que } \\
\text { contribuem para } \\
\text { habitalidade, como } \\
\text { bancos, muretas } \\
\text { coberturas e presença } \\
\text { de vegetação. Estes } \\
\text { são elementos que } \\
\text { visibilizam o acolhimento } \\
\text { do espaço em relação ao } \\
\text { habitante. } \\
\end{array}$ & $\begin{array}{l}\text { Croquis para } \\
\text { visualização do espaço } \\
\text { em momentos diversos, } \\
\text { buscando identificar } \\
\text { diferentes intensidades } \\
\text { de ocupação e uso do } \\
\text { espaço em diferentes } \\
\text { periodos do dia, semana, } \\
\text { mês e/ou ano. }\end{array}$ & $\begin{array}{l}\text { Croquis como ferramenta } \\
\text { de imaginação das } \\
\text { apropriações possiveis } \\
\text { para determinado lugar, } \\
\text { desenvolvidos a partir } \\
\text { das memórias afetivas } \\
\text { coletivas em relação ao } \\
\text { espaço analisado. }\end{array}$ \\
\hline & Diagramas & & $\begin{array}{l}\text { Diagrama como } \\
\text { ferramenta para } \\
\text { sintetizar as relações } \\
\text { identificadas. } \\
\text { Caracterização do } \\
\text { caráter das fronteiras } \\
\text { espaciais, por meio de } \\
\text { elementos gráficos. }\end{array}$ & $\begin{array}{l}\text { Diagramas para } \\
\text { mapeamento dos } \\
\text { elementos presentes } \\
\text { nos espaços analisados. } \\
\text { Visão sintética } \\
\text { dos elementos de } \\
\text { acolhimento que } \\
\text { compõem o espaço. } \\
\text { Identificação da escala } \\
\text { em que cada elemento } \\
\text { opera, revelando } \\
\text { como as escalas da } \\
\text { hospitalidade atuam de } \\
\text { modo integrado. } \\
\end{array}$ & $\begin{array}{l}\text { Diagrama de ritmos } \\
\text { refletindo as diferentes } \\
\text { intensidade de uso } \\
\text { social em cada trecho } \\
\text { da fronteira do espaço. } \\
\text { Registro da ausência } \\
\text { de constância de uma } \\
\text { percepção hospitaleira } \\
\text { do espaço, pois um } \\
\text { ambiente não se define } \\
\text { exclusivamente por sua } \\
\text { estrutura fisica, mas } \\
\text { também por meio da sua } \\
\text { dinâmica social. } \\
\end{array}$ & $\begin{array}{l}\text { Mapas mentais para } \\
\text { sintetizar informações } \\
\text { acerca do lugar, como } \\
\text { palavras, sentimentos } \\
\text { e imagens, frutos das } \\
\text { recordações registradas. }\end{array}$ \\
\hline & $\begin{array}{l}\text { Desenho de detalhe } \\
\text { para mensurar } \\
\text { distâncias e } \\
\text { tamanhos }\end{array}$ & & \begin{tabular}{|l} 
Desenho, em escala \\
aproximada, com \\
dimensionamento dos \\
vãos que delimitam \\
a abertura de um \\
espaço, contraposto às \\
dimensões humanas.
\end{tabular} & $\begin{array}{l}\text { Desenho, em escala } \\
\text { aproximada, com } \\
\text { dimensionamento dos } \\
\text { elementos, procurando } \\
\text { identificar relação com } \\
\text { as dimensões humanas. }\end{array}$ & & \\
\hline & Colagem & & $\begin{array}{l}\text { Justaposição de imagens } \\
\text { que definem a fronteira } \\
\text { e sua abertura ao } \\
\text { habitante. A aglutinação } \\
\text { dessas imagens traz } \\
\text { à tona a dimensão } \\
\text { subjetiva de um espaço } \\
\text { aberto fisicamente. }\end{array}$ & $\begin{array}{l}\text { Aglutinação de imagens } \\
\text { relativas a apropriação } \\
\text { dos elementos pelos } \\
\text { habitantes. Por meio } \\
\text { da colagem é possivel } \\
\text { imaginar formas } \\
\text { de habitar o lugar, } \\
\text { compreendendo melhor } \\
\text { os elementos que o } \\
\text { compõem. }\end{array}$ & $\begin{array}{l}\text { Justapor imagens de } \\
\text { modo a expressar } \\
\text { os ciclos do lugar e/ } \\
\text { ou as ambiências que } \\
\text { o compõem. Deste } \\
\text { exercicio podem surgir } \\
\text { colagens com resultados } \\
\text { variados já que o lugar } \\
\text { possui uma frequência } \\
\text { de vitalidade que varia } \\
\text { continuamente. }\end{array}$ & $\begin{array}{l}\text { Justaposição de imagens } \\
\text { que representem } \\
\text { memórias individuais } \\
\text { e coletivas, buscando } \\
\text { aproximar-se dos } \\
\text { sentimentos em relação } \\
\text { ao lugar. A aglutinação } \\
\text { visual das vivências } \\
\text { do lugar analisado não } \\
\text { esgotam, no entanto, } \\
\text { suas possbilidades. }\end{array}$ \\
\hline
\end{tabular}

Figura 47: Matriz de análise da hospitalidade

Fonte: Elaborado pela autora 


\section{Considerações finais}

A crise da arquitetura moderna fomentou a reflexão acerca da experiência humana do espaço. As dimensões corporais e mentais da existência humana, que vinham sendo continuamente suprimidas, assumem papel importante neste momento. É nesse âmbito que uma arquitetura da hospitalidade se mostra tão pertinente. Podemos concluir levando em conta esse contexto de demanda por cidades mais humanas que uma das tarefas do arquiteto seja tonar hospitaleiro aquilo que é inóspito. Transformar um dado espaço em um lugar que acolhe ao habitante é o desafio que a hospitalidade coloca.

O contexto atual que impôs o distanciamento social em função da pandemia causada pela disseminação do COVID-19 aprofunda a reflexão acerca de cidades mais humanas. A crise no âmbito da saúde se alastrou para o âmbito social e psicológico. A distância física entre pessoas, necessária para evitar novos contágios, afetou profundamente a sociabilidade e saúde mental dos habitantes. A ausência de encontros sociais somada ao isolamento físico que limitou cada vez mais a vivência das cidades resultou em uma discussão acerca do que de fato constitui uma cidade saudável. Os espaços das casas revelaram-se insuficientes para as vivências humanas. Com isso as relações de afeto que se estabelecem entre habitante e lugar foram comprometidas, pois relações de proximidade se revelaram neste momento fundamentais para a experiência humana do espaço. A vida das pessoas foi profundamente impactada por essa nova dinâmica, que apresenta à arquitetura e urbanismo um importante desafio: encontrar estratégias para operar em um ambiente pandêmico, e pós pandêmico, que garantam o acolhimento dos habitantes de modo a gerar lugares que contribuam de modo positivo para a saúde física e mental deles.

Experenciamos a hospitalidade de diversas maneiras. A hipótese aqui colocada foi a de que ela opera em variadas escalas. Escala do corpo, escala do edifício e escala urbana atuam de modo coextensivo no acolhimento do habitante. Experiências aconchegantes dependem de variados fatores. O olhar voltado 
exclusivamente para uma escala de projeto não é suficiente para a compreensão da hospitalidade como um todo. Uma arquitetura da hospitalidade se dá a partir de estratégias que gerem lugares que cuidem dos seres humanos que nele habitam. Um arquiteto não projeta apenas objetos físicos que compõem uma cidade, mas imagens e sentimentos das pessoas que os habitam, determinando como será a experiência do lugar habitado. A forma arquitetônica, suas texturas, seus efeitos de luz e sombra e sua relação com o entorno, entre outros fatores, estão diretamente relacionadas ao modo pela qual a arquitetura é vivenciada.

A relação afetiva que se estabelece com o ambiente construído é primordial na compreensão do sentimento de acolhimento. Um lugar da hospitalidade cria fortes laços afetivos do habitante em relação ao espaço. Por esse motivo a dimensão mental da experiência humana do espaço não pode ser suprimida na investigação acerca da hospitalidade em arquitetura. A leitura dos elementos que impulsionam o acolhimento deve ser feita levando em conta a dimensão física paralelamente à dimensão mental da experiência.

Gestos de hospitalidade podem ser encontrados em todo lugar. Em uma maçaneta, em uma porta, em um banco de praça, nos materiais que empregamos em uma obra, nas relações de proximidade que se estabelecem a partir da evolução urbana, ou até mesmo na sombra gerada pela marquise de um edifício. Há um sentido de acolhimento em todas as coisas do mundo em que habitamos. Desde o gesto mais simples até aquele mais elaborado. Um lugar da hospitalidade depende que as escalas do espaço sejam vistas, portanto, de modo complementar.

A figura abaixo (Figura 48) apresenta as nuances onde a arquitetura da hospitalidade se encontra. É na interseção onde gestos em escalas diversas se complementam que encontramos o lugar da hospitalidade. Reprodução de gestos isolados não garantem o acolhimento. A hospitalidade depende de um conjunto de fatores que procuram cuidar de quem que habita determinado lugar. 


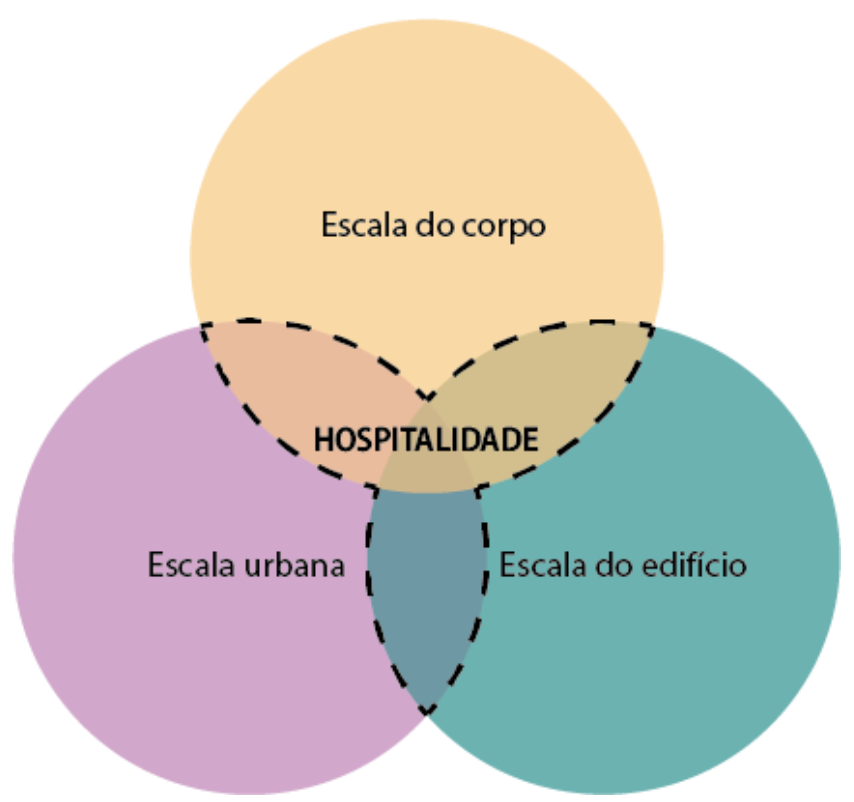

Figura 48: Diagrama nuances da hospitalidade

Fonte: Elaborado pela autora

Não existe uma fórmula que produza e defina hospitalidade. Mas o sentimento humano claramente compreende alguns espaços como mais hospitaleiros do que outros. Algumas conformações espaciais contribuem para isso, mas é importante ressaltar que dependem também de um contexto propício para tal.

A cultura também é um aspecto extremamente importante ao classificarmos um espaço como hospitaleiro ou não. As características de um lugar acolhedor no Rio de Janeiro diferem das características de um lugar acolhedor em Lisboa, ou de qualquer outra localidade. Não é possível transpor as características de um lugar hospitaleiro para outro espaço sem levar em conta o contexto no qual se insere. A esfera cultural influencia profundamente o comportamento humano e, por consequência, sua relação com o espaço. Por isso este é um dado importante para compreender o lugar da hospitalidade.

Quando a cidade é reconhecida como um lugar afetivo, ela se torna um símbolo de refúgio e abrigo na mente de seus habitantes. Isso significa que acolher o ser humano por meio de gestos de hospitalidade comunica diretamente com a sensação de bem-estar humano e com seus sentimentos em relação ao lugar. Uma arquitetura da hospitalidade demanda um olhar atento à vivência humana do lugar. Assim se constrói uma arquitetura da hospitalidade: por meio de gestos atentos à 
experiência humana do espaço. Por isso, quando falamos em hospitalidade revelase tão importante a postura de transpor-se para o lugar do outro, no intuito de prefigurar a vivência humana do espaço. Construir lugares da hospitalidade significa construir para o ser humano, de modo atento a dimensão do corpo e a percepção dele no espaço.

As fronteiras do espaço construído são zonas primordiais para a realização desse acolhimento em arquitetura. Por se tratar de limites de transição, quando dotadas de certa "porosidade", são capazes de estabelecer um território interconectado e hospitaleiro, capaz de recepcionar aquele que chega. A abertura é, portanto, condição para a hospitalidade. É por meio do tratamento das fronteiras que se faz a costura entre diferentes espaços, dando origem aos lugares do acolhimento. Desenhar as fronteiras do espaço urbano contemporâneo é um dos principais desafios, e portanto, também um dos gestos principais onde a arquitetura da hospitalidade pode atuar. Por meio dessas fronteiras que se estabelecem os primeiros gestos de recepção do indivíduo e por meio dela que se desenvolve uma cidade hospitaleira para seus habitantes. Isso fica evidente na Praça das Artes (São Paulo) e no Centro universitário Maria Antonia (São Paulo). Ambos os espaços de caráter cultural e coletivo criam uma relação de fluidez com o espaço da rua. Espaço público e espaço privado se encontram e ficam diluídas numa fronteira de caráter coletivo. As cavidades do espaço conformam o "espaço entre" que recepciona aquele que chega. Uma arquitetura da hospitalidade, portanto, independente do fato do edifício ser público ou privado. O espaço privado pode, e deve, ser tão social quanto o espaço público. Como apontado por M. Sola-Morales, a boa cidade é aquela em que os edifícios privados também carregam valores sociais. O modo como os edifícios tocam o solo ou a forma como recepcionam a quem chega determinam o caráter hospitaleiro do lugar, seja ele público ou privado.

Enquanto arquitetos, nós desenhamos fronteiras continuamente, a cada projeto. O modo como essas fronteiras são pensadas de modo a acolher os habitantes, será determinante na realização do lugar da hospitalidade. É impossível dissociar o projeto de um edifício das fronteiras que compõem o espaço urbano. Esses limites enquanto barreira ou integração são pouco a pouco delimitados a cada projeto que compõem a cidade. 
Os estudos de caso propostos possuem um ponto de contato que de algum modo sintetiza e simboliza a hospitalidade por meio da arquitetura: o banco. Com alturas que variam de 40 a $80 \mathrm{~cm}$, os bancos-muretas, elemento comuns, estabelecem diferentes relações com o corpo humano, possibilitando diferentes formas de habitar o espaço público. O banco transforma um espaço em lugar. "O banco não é somente espaço, mas também tempo, um elemento pré-disposto à pausa, que é sempre um convite a parar, parar no tempo, parar o tempo"203. No entanto, o ato de inserir bancos, ou muretas, no espaço por si só não garante hospitalidade ao lugar. Ao colocar um banco em dado espaço, o arquiteto determina o lugar onde sentar-se, controlando o que se vê durante a pausa que o banco, enquanto elemento, estimula. $\mathrm{O}$ banco pode, por isso, se tornar um lugar acolhedor ou inóspito para o habitante. Ademais, o banco como dimensão isolada não assegura sozinho o acolhimento. Ele opera junto às demais dimensões da hospitalidade, em consonância com o contexto no qual se insere. Sendo assim, a mureta depende de áreas sombreadas, da intensidade da vivência social do espaço e do nível de abertura deste espaço em relação seu entorno.

Outro aspecto importante é que a escala humana é a escala das relações sociais. Incorporar este fator no projeto dos espaços, de modo a suscitar trocas sociais e convívio entre os habitantes garante a construção de cidades mais humanas. Espaços que não só permitem como estimulam o convívio social são tidos com espaços acolhedores para os habitantes, pois a presença de outras pessoas também pode ser considerada um fator que garante hospitalidade ao lugar. Por isso, frequentemente, lugares hospitaleiros são espaços marcados pela vitalidade da presença humana. Em uma via de mão dupla, quanto mais acolhedor, maior vai ser a utilização do espaço, e, por outro lado, quanto mais vitalidade pelo convívio social, maior a sensação de acolhimento em relação ao lugar. Da mesma forma que espaços desertos podem ser considerados inóspitos, a falta de hospitalidade de um espaço pode inviabilizar a apropriação dele pelos habitantes.

Sob este aspecto, ao observar a apropriação desses lugares marcados por gestos de hospitalidade, observou-se que as chamadas fronteiras da hospitalidade tendem a expandir sua espessura. Isso significa que esses espaços apresentam uma característica comum: expandem-se para além da delimitação convencional, 
adquirindo ainda mais espessura por meio da apropriação dos habitantes. Uma fronteira hospitaleira tende a concentrar pessoas e encontros e por vezes, sua largura não dá conta do elevado nível de interações sociais. Por isso elas se expandem naturalmente, apropriando-se dos espaços das ruas ao redor e integrando-se ao comércio circundante. Este pode ser considerado um indício da fronteira da hospitalidade. Observa-se este processo, com frequência, na mureta da Urca. O espaço das vias é, aos poucos, absorvido pela mureta devido ao elevado número de frequentadores em alguns períodos.

O diagrama a seguir (Figura 49) revisita o diagrama desenvolvido no capítulo 2 (que buscava sintetizar a relação entre os conceitos investigados) com o intuito de adicionar uma camada oriunda da conclusão desta pesquisa. O modo de habitar estruturado a partir de dimensões da hospitalidade gera uma expansão do lugar. A camada adicionada procura expressar que a contida delimitação anterior se expande por meio do acolhimento do espaço, gerando uma fronteira cada vez mais espessa e menos rigidamente delimitada. Ou seja, a fronteira não se dilata de modo regular por meio das dimensões do acolhimento. Cada trecho revela um nível de dilatação de acordo com as interações sociais que se estabelecem ali. Este processo de expansão da fronteira revela também um aspecto recorrente em espaços hospitaleiros: a adaptabilidade às diferentes formas de vivência humana do espaço. Ambientes rígidos que não toleram diferentes apropriações tendem a ser menos acolhedores. Ao estar aberto a variadas possibilidades, o espaço se abre ao habitante, permitindo a construção de variadas memórias afetivas em relação a um mesmo lugar. 


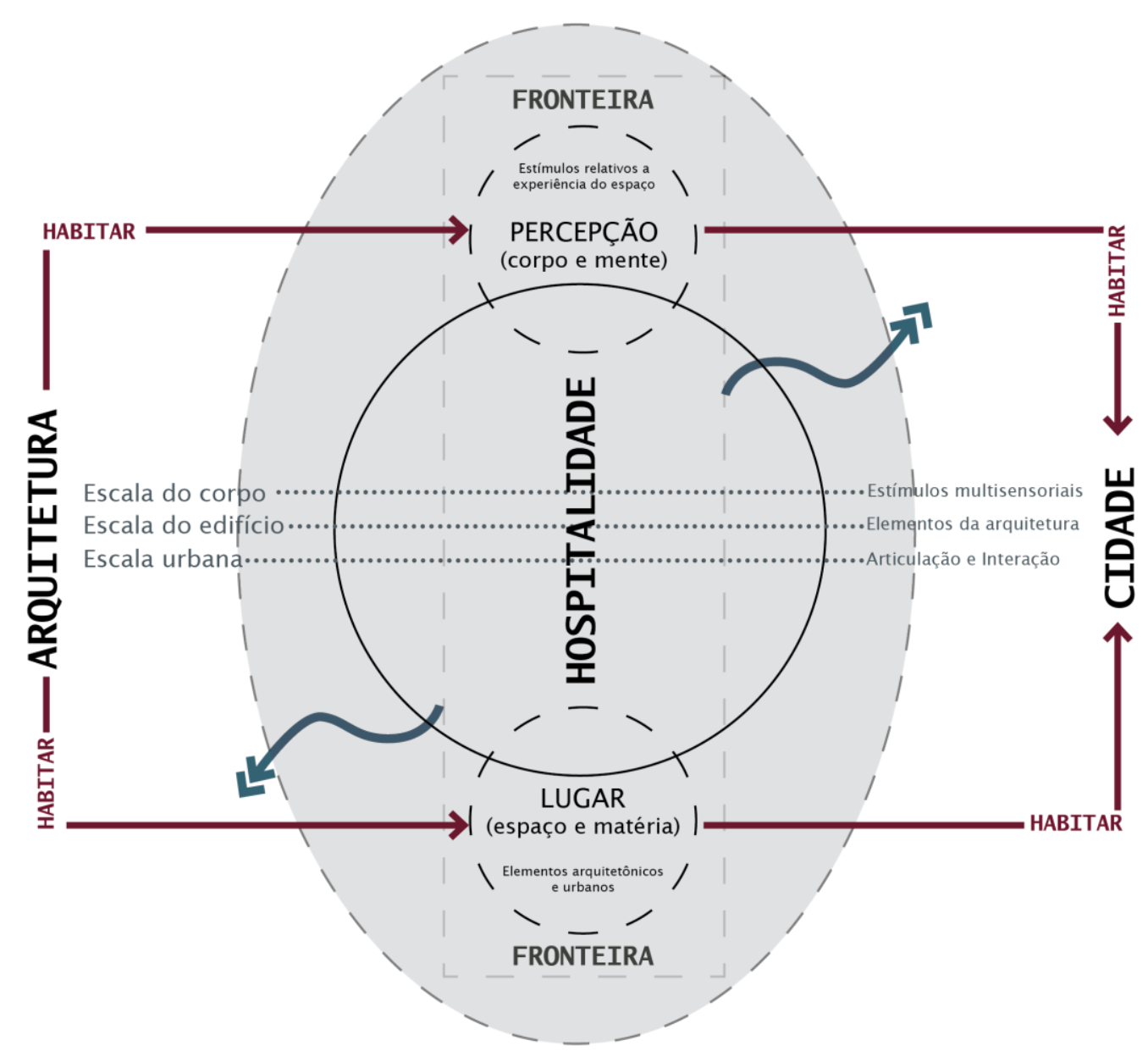

Figura 49: Diagrama conceitual fronteira expandida

Fonte: Elaborado pela autora

Conceber a fronteira como um lugar da hospitalidade demanda um cuidadoso olhar para os limites que compõem o tecido urbano. A chave está muito mais suavização desses hiatos espaciais do que na realização de projetos notórios e emblemáticos. A pesquisa procurou reconhecer nas diversas abordagens projetuais, de diferentes períodos históricos e contextos geográficos, gestos que conferem acolhimento ao lugar por meio da arquitetura. Desse olhar contínuo, conclui-se que hospitalidade não depende exclusivamente de grandes obras ou grandes intervenções espaciais. Ela está presente também no chamado infra-ordinário ${ }^{204}$, composto pelo comum e presente no nosso cotidiano. Mais do que estratégias 
projetuais, buscam-se aqui gestos de hospitalidade. Dessa maneira, uma arquitetura da hospitalidade não depende de grandes investimentos, mas de gestos acolhedores.

A relevância desses gestos em uma hospitalidade na arquitetura reforça a ideia de que a microescala explica a macroescala. $\mathrm{O}$ detalhe de um banco ou a especificação de um material são pequenos gestos que impactam o lugar em sua totalidade. Um ambiente atento à escala humana em seus detalhes gera um lugar hospitaleiro. Desenhar o acolhimento do habitante não é uma tarefa simples. Demanda a pré-visualização da vivência humana do espaço e dos modos do ser humano se relacionar com o lugar. É esse tratamento que permite habitar a fronteira da hospitalidade. Uma fronteira que recepciona, acolhe e estabelece relações de afeto entre habitantes e lugar.

Em um extremo oposto da arquitetura da hospitalidade encontra-se a arquitetura hostil, que vem sendo continuamente discutida ${ }^{205}$. Uma arquitetura hostil lança mão de artifícios, como inserção de fragmentos pontiagudos em áreas planas, para impedir a apropriação destes espaços por moradores em situação de rua, principalmente nos centros urbanos. O objetivo dessas intervenções espaciais é afastar habitantes indesejáveis do espaço urbano, excluindo-os do convívio social e ignorando uma dura realidade por meio de estratégias que, além de não solucionarem a questão, agravam o contexto de marginalização destas pessoas. A hostilidade desse, e outros gestos, incorporados ao espaço afastam-no da transformação em lugar. A falta de gentileza desses espaços com os seres humanos reforça a demanda por cidades mais humanas anteriormente mencionada. Tal realidade é ainda agravada em um contexto pandêmico e pós pandêmico, chamando atenção para a urgência em realizar a transição de uma arquitetura hostil para uma arquitetura da hospitalidade. Técnicas que desencorajam o uso do espaço por moradoras de rua encontram diametralmente opostas aos gestos do acolhimento aqui investigados. A hospitalidade, em essência, significa acolher de modo irrestrito aquele que chega. Essa hostilidade espacial, cada vez mais frequente nas cidades

205 Aprovado em 31/03/2021 projeto de lei (PL 488/2021) que, de acordo com a explicação da ementa, "veda o emprego de técnicas de arquitetura hostil, destinadas a afastar pessoas em situação de rua e outros segmentos da população, em espaços livres de uso público" (Fonte: Senado Federal). O Conselho de Arquitetura e Urbanismo do Brasil apoia a proposta, mas, no entanto, julgou inadequada a utilização do termo que associa arquitetura à hostilidade. De acordo com Nadia Somekh, "a essência da arquitetura é o acolhimento, então é incongruente falar em arquitetura hostil, foi um termo infeliz cunhado por um jornalista britânico e lamentavelmente adotado no Brasil sem uma visão crítica" (Fonte: CAU BR) 
contemporâneas, limita profundamente a experiência humana do espaço e inviabiliza uma cidade viva e saudável.

A demanda por lugares da hospitalidade onde possamos habitar possui uma dimensão política e uma dimensão estética, intimamente relacionadas entre si. Acolher aquele que chega à soleira é um gesto (po)ético. A poética do acolhimento se dá por meio uma porta ou de um vão, por meio de um banco ou de uma mureta, por meio da textura dos materiais, sensível ao toque, ou da paisagem que se contempla. A hospitalidade é ao mesmo tempo material e imaterial, as vezes podemos tocá-la, outras vezes podemos apenas senti-la. Arquiteturas da hospitalidade podem ser encontradas em todo lugar que disponha do desejo de acolher aquele que chega, despertando nele sentimentos de afeto e criando memórias espaciais afetivas. Por meio das arquiteturas da hospitalidade, autorais ou não, somos acolhidos e estimulados a imaginar novas possibilidades para uma arquitetura da hospitalidade. 


\section{Referências Bibliográficas}

ARISTARKHOVA, Irina. Architectures of Hospitality (palestra). Evento virtual. 9 de março de 2021

BACHELARD, G. A poética do espaço. São Paulo: Martins Fontes, 1993

CASTEllo, L. A percepção do lugar: repensando o conceito de lugar em arquitetura-urbanismo. Porto Alegre: PROPAR/UFRGS, 2007

Lugares de urbanidade. Curitiba: CRV, 2017

DEL RIO, Vicente; DUARTE, Cristiane Rose de Siqueira; RHEINGANTZ, Paulo Afonso. Projeto do lugar: colaboração entre psicologia, arquitetura e urbanismo. Rio de Janeiro: Contra Capa, 2002.

DAMÁSIO, A. O erro de Decartes: emoção, razão e cérebro humano. São Paulo: Companhia das Letras, 2012

DERRIDA, J.; DUFOURMANTELLE, A. Anne Dufourmantelle convida Jacques Derrida a falar da hospitalidade. São Paulo: Escuta, 2003

DUARTE, C. A empatia espacial e sua implicação nas ambiências urbanas. Revista Projetar, Projeto e Percepção do Ambiente, Abril, 2016

EBERHARD, J. "Architecture and Neuroscience: A Double Helix". In: PALLASMAA, J; ROBINSON, S. Mind in Architecture: Neuroscience, Embodiment, and the Future of Design. Massachusetts: The MIT Press, 2015

ESPÓSITO G., F. El afecto en la arquitectura: la relacion arquitecto-lugarhabitante a traves de la experiencia del proyecto. Barcelona, 2011. 360p. Tese de doutorado - E. Tècnica Superior d'Arquitectura de Barcelona, Universitat Politécnica de Catalunya

El afecto en la arquitectura: La relación entre arquitecto, lugar y habitante en la experiencia contextual del proyecto. Arquiteturarevista (UNISINOS), v. 8, p. 8-16, 2012

ESPOSITO, F.; SANSÃO, A.; ZIGONI, C. La Plaza São Salvador, Río de Janeiro, Brasil. La música como catalizador de apropiaciones en el espacio urbano. Revista Planeo, v. 30, p. 1-1, 2016.

FARIAS, A. Poéticas da hospitalidade. Ensaios para uma filosofia do acolhimento. Porto Alegre: Zouk, 2018.

FERREIRA, Aurélio Buarque de Holanda. Novo dicionário Século XXI: o dicionário da língua portuguesa. Rio de Janeiro: Nova Fronteira, 1999

FUÃO, F. As formas do acolhimento na arquitetura. In SOLIS, Dirce Eleonora Nigro; FUÃO, Fernando Freitas. Derrida e arquitetura. Rio de Janeiro: EdUERJ, 2015

GEHL, J. Cidade para pessoas. São Paulo: Perspectiva, 2013

La humanización del espacio urbano: la vida social entre los edificios.

Barcelona: Reverté, 2006 
HERTZBERG, H. Lições de arquitetura. São Paulo: Martins Fontes, 1999

HIGINO, N. Álvaro Siza: Desenhar a Hospitalidade. Porto: Casa da Arquitectura, 2010

INGOLD, T. "Culture, perception and cognition". In:

The perception of

the enrironment. Essays on livehood, dwelling and skill. Londres: Routledge, 2000

"Building, dwelling, living: How animals and people make themselves at home in the world". In: The perception of the enrironment. Essays on livehood, dwelling and skill. Londres: Routledge, 2000

INNERARITY, D. Ética de la hospitalidad. Barcelona: Ediciones Península, 2001

JACOBS, J. A maldição das zonas de fronteira desertas. In: Morte e vida de grandes cidades. São Paulo: Martins Fontes Paulista, 2009

JÜRGENHAKE, Birgit. Connecting Inside and Outside in Time-Base Dwelling. Nordic Journal of Architectural Research, 2006. Disponível em: <http://arkitekturforskning.net/na/article/view/159>. Acesso em: 05 nov. 2019

KOOLHAAS, R. Elements of Architecture. Rotterdam: Taschen, 2018

LEFEBVRE, H. "A forma urbana”. In: . A Revolução Urbana. Belo Horizonte: Ed. UFMG, 1999, pp. 109-124

LEFEBVRE, H. “Conclusão". In: A Revolução Urbana. Belo Horizonte: Ed. UFMG, 1999, pp. 165- 171

LYNCH, K. A imagem da cidade. 3. ed. São Paulo: Wmfmartinsfontes, 2011

MONTANER, Josep Maria. A condição contemporânea da arquitetura. São Paulo: Gustavo Gili, 2016

Do diagrama às experiências, rumo a uma arquitetura de ação. São Paulo: Gustavo Gili, 2017

NOBERG-SCHULZ, C. Genius Loci. Towards a Phenomenology of Architecture. Nova Iorque: Rizzoli, 1980

Intenciones en arquitectura. Barcelona: Gustavo Gili, 2001.

Kahn, Heidegger and the language of architecture. Oppositions, 1979.

PAESE, C.; MARIANO, Gabriela F.; MOREIRA, Lizandra M. Cartografia da Hospitalidade. In: V ENANPARQ, 2018, Salvador, Bahia. Arquitetura e Urbanismo no Brasil atual: crises, impasses e desafios. Salvador - Bahia: UNIVERSIDADE FEDERAL DA BAHIA, 2018. v. 1. p. 1551-1563

PALLASMAA, J. Essências. São Paulo: Gustavo Gili, 2018

Habitar. São Paulo: Gustavo Gili, 2017

Os olhos da Pele. Porto Alegre: Bookman, 2011

"A geometria do sentimento: um olhar sobre a fenomenologia da arquitetura". In: NESBITT, Kate (org.). Uma nova agenda para a arquitetura: antologia teórica (1965 - 1995). São Paulo. Cosac Naify, 2008

.; ROBINSON, Sarah. Mind in Architecture: Neuroscience, Embodiment, and the Future of Design. Massachusetts: The MIT Press, 2015. 
PEDROSA, A.; CUY, J. E. C.; GONZÁLEZ, J.; TOLEDO, T. (Org.). Lina Bo Bardi: Habitat. 1ed.São Paulo: Museu de Arte de São Paulo, 2019

PEREC, Georges. Aproximações do quê? Alea, Rio de Janeiro, v. 12, n. 1, p. 177 180, junho 2010. Disponível em: <http://www.scielo.br/scielo.php?script=sci_arttext\&pid=S1517106X2010000100014\&lng=en\&nrm=iso>. Acessado em 02 Mar. 2021

RASMUSSEN, S. Arquitetura vivenciada. São Paulo: Martins Fontes, 2015 SANSÃO, A.; FAGERLANDE, S. O público, o coletivo e o privado: diálogos contemporâneos. In: I Congresso Internacional Espaços Públicos, 2015, Porto Alegre. Anais do I Congresso Internacional Espaços Públicos. Porto Alegre: EDIPUCRS. v. 1. p. 1-10.

SENNETT, R. Construir e Habitar. Ética para uma cidade aberta. Rio de Janeiro, Record, 2018.

SOLÀ-MORALES, I. de. Presente y futuros: arquitectura en la ciudad. Barcelona, $1996 . \quad$ Disponível em: <http://search.ebscohost.com/login.aspx ?direct=true\&db=edsbas\&AN=edsba s.CC6ACD5F\&lang=pt-br\&site=eds-live\&scope=site>. Acesso em: 19 abr. 2020

SOLÀ-MORALES, M. "Espacios públicos y espacios colectivos". Revista Universitaria $\mathrm{n}^{\circ}$ 46. Ediciones Pontificia Universidad Católica de Chile, Santiago, 1994

SOLIS, D. "Jacques Derrida e a ética da hospitalidade". Revista de Filosofia Seaf, ano V, n.5, nov 2005

TUAN, Y. Topofilia: um estudo da percepção, atitudes e valores do meio ambiente. Londrina: Eduel, 2012

Espaço e lugar. A perspectiva da experiência. Londrina: Eduel, 2012

VELLOSO, R. Experiência estética, arquitetura urbana. Cadernos de Arquitetura e Urbanismo, v17, n21, 2010

ZEVI, B. Saber ver a arquitetura. São Paulo: WMF Martins Fontes, 2009

ZUMTHOR, P. Atmosferas: entornos arquitectónicos: as coisas que me rodeiam. Barcelona: Gustavo Gili, 2009 